INTEGRATED MINED-AREA RECLAMATION AND LAND USE PLANNING

\author{
Volume 4
}

A Bibliography of Integrated Mined-Area Reclamation and Land Use Planning, with Annotations

\title{
Prepared for the
}

Resources and Land Investigations (RALI) Program

U. S. Department of the Interior and

U. S. Geological Survey

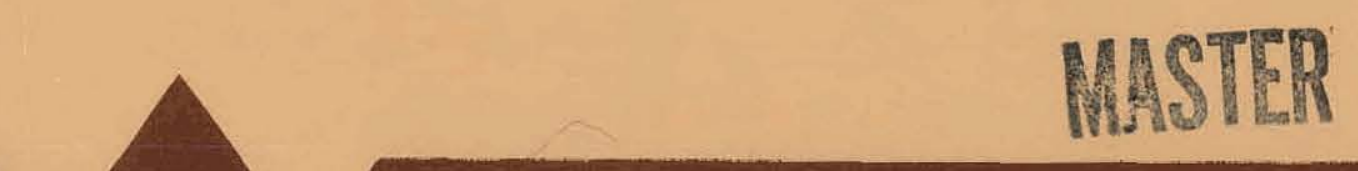

\section{ENERGY AND MINERAL RESOURCES}

\author{
ARGONNE NATIONAL LABORATORY
}

Energy and Environmental Systems Division

Operated by

U. S. ENERGY RESEARCH AND DEVELOPMENT ADMINISTRATION 


\section{DISCLAIMER}

This report was prepared as an account of work sponsored by an agency of the United States Government. Neither the United States Government nor any agency Thereof, nor any of their employees, makes any warranty, express or implied, or assumes any legal liability or responsibility for the accuracy, completeness, or usefulness of any information, apparatus, product, or process disclosed, or represents that its use would not infringe privately owned rights. Reference herein to any specific commercial product, process, or service by trade name, trademark, manufacturer, or otherwise does not necessarily constitute or imply its endorsement, recommendation, or favoring by the United States Government or any agency thereof. The views and opinions of authors expressed herein do not necessarily state or reflect those of the United States Government or any agency thereof. 


\section{DISCLAIMER}

Portions of this document may be illegible in electronic image products. Images are produced from the best available original document. 
The facilities of Argonne National Laboratory are owned by the United States Government. Under the terms of a contract (W-31-109-Eng-38) between the U. S. Energy Research and Development Administration, Argonne Universities Association and The University of Chicago, the University employs the staff and operates the Laboratory in accordance with policies and programs formulated, approved and reviewed by the Association.

\section{MEMBERS OF ARGONNE UNIVERSITIES ASSOCIATION}

The University of Arizona Carnegie-Mellon University Case Western Reserve University The University of Chicago University of Cincinnati Illinois Institute of Technology University of Illinois Indiana University Iowa State University The University of Iowa
Kansas State University The University of Kansas Loyola University Marquette University Michigan State University The University of Michigan University of Minnesota University of Missouri Northwestern University University of Notre Dame
The Ohio State University

Ohio University

The Pennsylvania State University

Purdue University

Saint Louis University

Southern Illinois University

The University of Texas at Austin Washington University

Wayne State University

The University of Wisconsin

\section{NOTICE}

This report was prepared as an account of work sponsored by the United States Government. Neither the United States nor the United States Energy Research and Development Administration, nor any of their employees, nor any of their contractors, subcontractors, or their employees, makes any warranty, express or implied, or assumes any legal liability or responsibility for the accuracy, completeness or usefulness of any information, apparatus, product or process disclosed, or represents that its use would not infringe privately-owned rights. Mention of commercial products, their manufacturers, or their suppliers in this publication does not imply or connote approval or disapproval of the product by Argonne National Laboratory or the U. S. Energy Research and Development Administration. 
ARGONNE NATIONAL LABORATORY

9700 South Cass Avenue

Argonne, Illinois 60439

\section{INTEGRATED MINED-AREA RECLAMATION \\ AND LAND USE PLANNING}

Volume 4

A Bibliography of Integrated Mined-Area Reclamation and Land Use Planning, with Annotations*

hy

Leslie R. Lewis, James R. LaFevers, Allen 0 . Perry, and William Rice, Jr. - . . . .....

Energy and Environmental Systems Division

December 1976

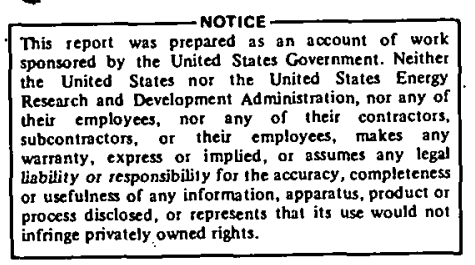

* Prepared for the Resource and Land Investigations (RALI) Program of the U. S. Department of the Interior with Funds Provided by the

U. S. Geological Survey 
THIS PAGE WAS INTENTIONALLY LEFT BLANK 
FOREWORD. . . . . . . . ................ $i_{v}$

ACKNOWLEDGMENTS . . . . . . . . . . . . . . . . . vi

PROGRAM STAFF...................... ... vii

ABSTRACT. . . . . . . . . . . . . . . . . . . . 1

INTRODUCTION. . . . . . . . . . . . . . . . . . . 2

1 BIBL̇IOGRAPHIES ON SURFACE MINING AND RECLAMATION TECHNOLOGY

AND RELATED LAND USE . . . . . . . . . . . . . . . . . . 7

1.1 Glossaries and Dictionaries . . . . . . . . . . . 9

2 LEGAL ASPECTS OF SURFACE MINING AND RECLAMATION. . . . . . . 11

3 ECONOMICS OF SURFACE MINING AND RECLAMATION. . . . . . . . 19

4 SURFACE MINING AND RECLAMATION TECHNOLOGY. . . . . . . . . 25

5 RECLAMATION METHODS AND TECHNOLOGY . . . . . . . . . . . . 37

5.1 General Works . . . . . . . . . . . . . . 37

5.2 Spoil Handling and Manipulation . . . . . . . . . 45

5.3 Erosion and Sediment Control. . . . . . . . . . . . 46

5.4 Revegetation. . . . . . . . . . . . . . . . 49

5.5 Spoil Amendments and Fertilization. . . . . . . . . . 54

5.6 Water Pollution Control . . . . . . . . . . . . . 55

5.7 Reclamation Research. . . . . . . . . . . . . . 57

6 INTEGRATED LAND USE AND RECLAMATION PLANNING . . . . . . . . 63

6.1 General Works . . . . . . . . . . . . . . . 63

6.2 Integrated Land Use and Reclamation Planning
Procedures and Guidelines . . . . . . . . . . . 78

6.3 Representative Ordinances, Plans, and Studies . . . . . 83

6.4 Performance Controls... . . . . . . . . . . . 85

6:5 Environmental and Social Impacts. . . . . . . . . 88

AUTHOR INDEX. . . . . . . . . . . . . . . . . . 93

SUBJECT INDEX . . . . . . . . . . . . . . . . . . . 103

GEOGRAPHIC INDEX. . . . . . . . . . . . . . . . . 113 
FOREWORD

This report is one in a series prepared by the Energy and Environmental Systems Division of Argonne National Laboratory and the Resource and Land Investigations (RALI) Program of the U.S. Department of the Interior with funds provided by the U.S. Geological Survey. The ten documents that comprise this series are closely interrelated and, although published in separate volumes, each will be most useful only when its relationship to the other products of the program is considered.

The reports in this series are designed primarily to familiarize professional land use and resource planners with the range of possibilities and effective procedures for achieving integrated mining, reclamation, and land use planning. These reports are based on a research program which included an extensive literature review, the compilation and analysis of case study data, and close coordination and interaction with related government programs. The first volume in the series is entitled "A Guide to Integrated Mined Area Reclamation and Land Use Planning," which summarizes the information in the other volumes and presents conclusions and observations drawn from analyses of that information.

Volume 2 is entitled "Methods and Criteria for Land Use and Resource Planning in Surface Mined Areas." This document examines planning procedures used in several mineral industries and mining regions and discusses problems facing professional planners who must consider surface mine areas in their planning programs.

In Volume 3, "A Guide to Mined Area Reclamation Technology for Reclamation and Land Use Planners," the methods used to reclaim land in each of several mineral industries are discussed in relation to the physical and cultural constraints that must be considered in planning a reclamation program. Much of the information for this document was obtained from case studies conducted in several mining districts. The case study sites were chosen after consideration of the following: (a) coverage by commodity of those surface mining activities which disturb the greatest acreages; (b) coverage of a variety of cultural and land use settings; (c) evidence of integration of mining, reclamation, and land use planning; (d) cooperation on the part of operating companies and appropriate planning entities; (e) coverage of a variety of surface mining and reclamation methods; and ( $f$ ) coverage of a variety of physical settings (geology, physiography, climate, hydrology). After the preliminary case study selection, some sites were changed and others dropped because of a lack of company cooperation. The remaining six case studies all meet the criteria listed above. They are not intended to be perfect examples of reclamation and planning procedures. Rather, they illustrate a variety of procedures utilized in different physical and cultural settings to achieve planning goals under a variety of technological, legal, and economic constraints.

Since the case studies are intended to be used as appendices to Volume 3 , they are numbered accordingly. The case study reports include:

Volume 3A, "A Case Study of Surface Mining and Reclamation Planning: South Boulder Creek Park Project, Sand and Gravel Operations, Boulder, Colorado;" 
Volume 3B, "A Case Study of Surface Mining and Reclamation Planning: International Minerals and Chemical Corporation, Phosphate Operations, Polk County, Florida;"

Volume 3C, "A Case Study of Surface Mining and Reclamation Planning: Georgia Kaolin Company, Clay Mines, Washington County, Georgia;"

Volume 3D, "A Case Study of Surface Mining and Reclamation Planning: Area Strip Coal Mining, Peabody Universal Mine, Universal, Indiana;"

Volume 3E, "A Case Study of Surface Mining and Reclamation Planning: ASARCD Open-Pit Copper Mine, Casa Grande, Arizona;"

Volume 3F, "A Case Study of Surface Mining and Reclamation Planning: Cannelton Mountain-Top Removal Coal Mine No. 9-S, Cannelton, West Virginia."

Volume 4 of this series is entitled "A Bibliography of Integrated Mined Area Reclamation and Land Use Planning, With Annotations.". This bibliography includes primarily references pertinent to reclamation planning and plan implementation. 
The authors would like to extend a note of gratitude to the individuals and organizations whose assistance and helpful advice were instrumental in compiling this bibliography. Mr. Edgar A. Imhoff, Environmental Planner, RALI Program, provided important input to the basic approach on the scope and selection of works to be included. Mr. Michael J. Meshenburg, American Society of Planning Officials, was helpful in providing information from his organization's files. The authors want, also, to thank Joseph Camaioni and Robert Beck for their assistance in the compiling, indexing and coding of entries. Mr. Robert Major, Mineral Economist, now of Amax Coal Company, provided helpful review and informative comments. raphy, as follows:

The authors wish to thank those who assisted in reviewing this bibliog-

Dr. Allen Agnew, The Library of Congress.

Frank Beal, American Society of Planning Officials.

Dr. Roy E. Cameron, Argonne National Laboratory.

Denton Carlson, Bureau of Land Management.

Ralph P. Carter, Argonne National Laboratory.

Dr. Grant Davis, Surface Environment and Mining, U.S. Department of Agriculture.

Dr. Donald Everhart, International Minerals \& Chemical Corp.

James L. Gober, Tennessee Valley Authority.

Dr. J. Lee Guernsey, Indiana State University.

Gene Harris, U.S. Environmental Protection Agency.

Dr. Donald 0. Johnson, Argonne National Laboratory.

Ed McDowel1, Flatiron Companies.

Charles Medvick, Illinois Dept. of Mines \& Minerals.

Dr. Meredith E. Ostrom, State Geologist of Wisconsin.

Dr. John F. Tschanz, Argonne National Laboratory.

Donald Walker, Department of Real Estate Services, City of Boulder, Colorado.

Dr. Charles E. Wier, Amax Coal Co. 
$v i i$

Dr. James R. LaFevers, Program Manager

Allen 0 . Perry

Leslie R. Lewis

Jean E. Bogner

Ralph P. Carter

William R. Rice (student participant)

Robert Beck (student participant)

Energy and Environmental Systems Division,

Argonne National Laboratory

Edgar A. Imhoff, USGS-RALI/ANL Program Coordinator

Dr. Joseph O'Connor

Dr. Thomas Friz

Resources and Land Investigations Program,

U.S. Department of the Interfor

Dr. John L. Thames

Dr. Tika R. Verma

School of Renewable Natural Resources, University of Arizona

Dr. J. Lee Guernsey

Michael E. Tiller

Department of Geography, Indiana State University

Dr. Lawrence A. Brown

Troy State University of Fort Rucker, Alabama

Richard Fountain

Fountain and Associates

Winter Haven, Florida

Dr. Erkan Esmer

Esmer and Associates

Boomer, West Virginia 
viii

THIS PAGE

\section{WAS INTENTIONALLY}

LEFT BLANK 
INTEGRATED MINED-AREA RECLAMATION $\triangle N D$

LAND USE PLANNING

Volume 4: A Bibliography of Integrated Mined-Area

Reclomation and Land Use Planning,

with Annotations

ABSTRACT

This bibliography has been compiled for use by planners who, within their areas of responsibility, deal with the problems presented by surface mining, and reclamation. Every effort has been made to identify and to annotate those entries considered most useful in the development of plans for reclamation and after-mining land use. The coverage of varied surface mining and reclamation studies is intended to access the reader to documents and works related to legal, economic, and technological aspects: materials that treat with procedural, planning, and regulatory factors pertaining to land use and reclamation. The technical level of each annotated entry has been assessed to rank skills required for the comprehension and utilization of the work in question. This bibliography has been formulated to be used as a tool by municipal, county, and regional planners in a field of study in which guidelines are as yet few and diverse in approach. 
INTRODUCTION

Increased public and private concern for the ultimate fate of surface mined land has created pressure for the premining definition of future land uses and the development of reclamation plans compatible with land use goals. Effective planning for integrated mining and reclamation to ensure satisfactory postmining conditions and land use capabilities requires that planners becomie familiar with the relative merits and shortcomings of various surface mining and reclamation technologies and procedures. These technologies and procedures are closely related to the mineral commodities being mined and the natural setting of the region in which they occur. Although much information is available on mined land reclamation, it is usually directed toward the technical reader. Hence, it is usually of limited value to planning pro-. fessionals who may not have an extensive background in mining or reclamation engineering. A major goal of this document, therefore, is to provide land and resource planners of varying backgrounds with a means of access to the information they need.

\section{Purpose and Scope}

The annotated bibliography presented here is intended for use by reclamation and land use planners in determining what published information may be most useful to them in the development of integrated reclamation and land use plans. Every effort has been made in the compilation of this bibliography to review and to include the latest pertinent information available.

The bibliography includes reclamation information pertaining to economic and legal aspects, technology, and integration with appropriate land use planning. Relevant bibliographies compiled by other organizations or individuals are listed for further reference on specific aspects related to reclamation and planning. Works concerning reclamation technology, which have been reviewed and annotated, fall into several categories:

\footnotetext{
d. Spoil hand1ing and manipulation,

b. Erosion and sediment control,

c. Revegetation,

d. Spoil amendments and fertilization,

e. Water pollution control, and

f. Reclamation research.
}

Articles and publications cited within the bibliography apply to a variety of mineral commodities, geographic areas, and reclamation methods associated with each. In the compilation of this bibliography, literature relating to reclamation in a variety of mineral industries has been considered in order to provide information on reclamation procedures in coal, sand and gravel,.. porphyry copper, phosphate, kaolin, and other mining operations. 
Publications and articles relating to reclamation and land use planning have been cited and annotated. The categories of information covered include:

a. Integrated land use and reclamation planning procedures and guidelines,

b. Representative ordinances, plans, and studies,

c. Performance controls and standards, and

d. Environmental and social impacts.

\section{Compization Procedures}

Following the annotation of entries, and compilation of the data in final form, entries were cross-referenced by author, subject, and geographic area. While the review and annotation of data was in progress, all annotated entries were assigned keywords, coded, and entered into a Bibliographic Information Retrieval System (BIRS). The BIRS system was developed as a data base for both the Energy and Environmental Systems Division (EES) and this project. The operational characteristics and use of the system are outlined later in this discussion.

\section{Criteria for Selection and Annotation}

Such an extensive body of literature exists on surface mining, reclamation, and pertinent subjects that an all-inclusive bibliography would be both extremely difficult to compile and out of date by the time it was completed. Entries were selected on the basis of the following criteria:

1. Does the publication or article relate directly to integrated reclamation and land use planning?

2. Does the material have a bearing on some substantive aspect of reclamation or land use planning that would aid planners in the performance of their functions?

3. Are the materials available in English language version?

4. Is the material up to date in terms of time of publication, technology, and approach?

5. Is the material available to the general public and the planning community?

In addition to entries based on the above criteria, references to operations in other countries were also included, particularly those considered to possess a degree of transferability.

Criteria established for the selection of items for annotation differed somewhat from those used for initial selection. These additional criteria included: 
1. Techrifical background required for comprehension and ușe.

2. Value to planners in terms of usefulness and adaptability.

Those references considered to be particularly useful for integrated reclamation and land use planning have been annotated; due attention has been given to the needs of the less technical segment of the land use planning profession. The annotations have been structured so that the user will be able to determine quickly whether all or part of a particular publication will be of use, and many technical publications have been included to make them available to anyone wighing to investigate the more technical aspects of mined area reclamation and related land use planning.

\section{Data Sources}

In the course of compiling the bibliography, data were obtained from many sources, such as:

1. Federal agencies, especially the U.S. Department of the Interior, the U.S. Department of Agriculture, and the U.S. Environmental Protection Agency,

2. Universities and special institutes,

3. State mining regulatory offices,

4. State geological surveys,

5. State divisions for reclamation, pollution control, ecology, land management, and other government regulatory or information offices,

6. State, regional, or county planning offices, and

7. Industry associations and commercial publishing houses.

\section{Bibliographic Information Retrieval System (BIRS)}

Annotated materials in the Bibliography have been stored in the EES/BIRS system developed at Argonne National Laboratory for data storage and retirieval. The BIRS system uses a commercial data base management system, SYSTEM 2000, for data input, output, file mancigement, and data update. SYSTEM 2000 is a genera1-purpose data base management system developed by MRI Systems Corporation to operate on IBM 360 and 370 series, Univac 1100 series, and CDC 6000 and CYBER series computers. This SYSTEM 2000 feature, to work on different types of computers, makes the data base widely exchangeable. The basic SYSTEM 2000 provides the user with a comprehensive set of data base management capabilities that include the ability to define new data bases, to modify the definition of existing data bases, and to retrieve and update individual data values. An additional advantage is that the system, through its use of repeating groups, has no inherent limitation on keyword vocabulary or abstract length. For programming and use, SYSTEM 2000 (and BIRS) uses the PL/1 Procedural language for entry loading and the SYSTEM 2000 User Command Language for search and retrieval. 
The BIRS system has been designed to make data input and retrieval as simple as possible for users, while retaining capabilities for sophisticated data management. Data that have been stored in the system are coded to conform to the following format:

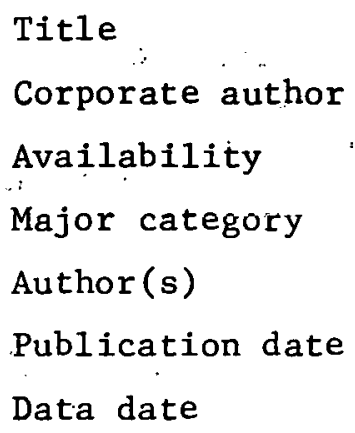

\begin{tabular}{llll} 
Major Category & 1st Sutcategory & 2nd Subcategory & Code \\
\cline { 2 - 3 } Hydrology & & $\ddots$ & H \\
& Surface & & SUR \\
& Subsurface & & SBSUR \\
& Water Qaulity & & WQUAL \\
Mine Drainage & & DRAIN \\
& & Acid & ACID \\
& & Alkaline & ALK
\end{tabular}

The BIRS system has the capability of date retrieval using several approaches. Data searches may be accomplished for authors, corporate authors, titles, categories, keywords, availability, geographic locality, and funding agencies. In addition, data from this project are stored using a modified generic keyword system and, in all cases, the keyword. RALI. A user's manual has been compiled for the BIRS system and will be available from R. R. MacDonald, EES Division, Argonne National Laboratory.

\section{Summary}

This annotated bibliography has been compiled for use by land and resource planners, who must deal with potential problems presented by surface mining and reclamation activities within their jurisdictional areas. Every 
effort has been made to identify and annotate those entries considered most useful in the development of plans for reclamation and postmining land use. The coverage of various disciplinary areas related to integrated surface mining, reclamation, and land use planning provides the user with access to documents and works on associated economic, legal, and technological aspects. Materials that pertain to the procedural and regulatory aspects related to land use and reclamation planning are included. The technical level of each annotated entry has been assessed in order to identify skills required for utilization of the work in question. The intent of this bibliography is to provide a useful tool for municipal, county, and regional planners. 
1 BIBLIOGRAPHIES ON SUREACE MINING AND RECLAMATION TECHNOLOGY AND RELATED LAND USE PLANNING*

1. W Preliminary Bibliography of Publications Concerning Rehabilitation of Lands Disturbed by Mining and Associated Activities for the Northem Great Plains Resources Progroms, U.S. Environmental Protection Agency, Rocky Mountain-Prairie Region, Denver, 19 pages (1973).

2 Bituminous Coal Research, Inc., Reclamation of Coal-Mined Land: $A$ Bibliography with Abstracts, Monroeville, Penn., 188 pages (Oct. 21, 1975).

3. Bowden, Charles, The Impact of Energy Development on Water Resources in Pu frid Lands: Literature Review and Annotated Bibliography, Arid Lands Resource Information Paper No. 6, Office of Arid Land Studies, University of Arizona, Tucson, 278 pages (Jan. 1975)

4. X Buwden, K. L., A Bibliography of Strip Mine Reclamation, Department of Conservation, University of Michigan, Ann Arbor, 13 pages (1961)

5. Brooks, D. B., Strip line Reclamation and Economic Analysis - BibliDup ography, Natural Resources J. 6:13-44, pub. by School of Law, University of New Mexico, Albuquerque (Jan. 1966).

6. Caldwell, N.B.; An Annotated Bibliography of the Surface-Mined Area X Restoration Research Project, U.S. Forest Service, Northeastern Forest Experiment Station, Berea, Ky., 21 pages. (1974).

7. Carpenter, L.H., and G.L. Williams, A Literature Review on the Role of - XMineral Fertilizers in Big Gome Range Improvement, Special Report No. 28, Colorado Division of Game, Fish, and Parks, Denver (1972).

8. Coaldrake, J.E., M. McKay, and P.A. Roe, Annotated Bibliography on the Ecology and Stabilization of Coastal Sand Dunes, Mining Spoils and X Other Disturbed Areas, Commonwealth Scientific and Industrial Research Organization (CSIRO), Division of Plant Industries, Canberra, Australia, 158 pages (1973)

9. Dalstead, N.L., and, F.L. Leistritz, A Selected Bibliography on CoalEnergy Development of Particular Interest to the Western States, $\checkmark$ Agricultural Economics Misc. Report No. 16, Department of igricultural Economics, North Dakota Agricultural Experiment Station, North Dakota State Universtiy, Fargo, 82 pages (April 1974).

10. Earney, F.C.F., Mining, Planning, and the Urban Environment: An Annotated Bibliography, 1960-1975, Exchange Bibliography 881, Council of Planning Librarians, Montice1lo, Ill., 36 pages (Sept. 1975).

*Refer to Sec. 6, Addendum, for additional sources that may or may not apply to previously classified sections. 
11. Frawley, M.L., Surface Mined Areas: Control and Reclamation of Environmental Damage, a Bibliography, Bibliography Series No. 27, U.S. Department of the Interior, Office of Library Services, Washington, D.C. (Sept. 1971).

12. Funk, D. T., A Revised Bibliography of Strip line Reclomation, Misc. Release No. 35, U.S. Forest Service, Central States Forest Experiment Station, Columbus, Ohio (1962).

13. Gifford, G.F., D.D. Dwyer, and B.E. Norton, A Bibliography of Literature Pertinent to Mining Reclamation in Arid and Semiarid Environments, The Environment and Man Program, Utah State University, Logan, Utah, 23 pages (1972).

14. Green, J. E., Selected Materials for Planning the Reclamation of $X$ Mined Land, Exchange Bibliography No. 795, Council of Planning Librarians, Monticello, I11., 8 pages (1975).

15. Hoffman, G.J., R.B. Curry, and G.0. Schwab, Annotated Bibliography on Slope Stability of Strip Mine Spoil Banks, Research C1rc. 130, Ohio $X$ Agricultural Experiment Station (now Ohio Agricultural Research and Development Center), Wooster, 92 pages (March 1964).

16. Honkala, R.A., Surface Mining and Land Reclamation: A Selected Op Bibliography, The old West Regional Commission, Washington, D.C., 154 pages (Oct. 1974).

17. Kieffer, F.v., A Bibliography of Surface Coal Mining in the U.S. to Dinfugust, 1971, Forum Associates, Columbus, Ohio, 71 pages (1972).

18 Laszkiewicz, O.T.M., Reclamation of Land Used for Mineral Industries, Strip Mines, Quarries, etc., Research Service Bibliography Series 4, No. 80, Public Library of South Australia, Adelaide, 18 pages (Dec. 1966).

19. Limstron, G.A., A Bibliography of Strip-Mine Reclamation, Misc. Release $Y$ No. 8, U.S. Forest Service, Central States Forest Experiment Station, $\checkmark$ Columbus, Ohio, 25 pages (1953).

20. Loomis, T.H.W., Compiled Research Data on Reclamation of Disturbed $X$ Lands in the Western United States, 1970, Bureau of Land Management U.S. Department of the Interior, Washington, D.C., 18 pages (1971).

21. Meshenberg, M.J., Environmental Planning: 2.A Selected Annotated Bibliography, Report No. 264, Planning Advisory Service, American X Society of Planning Officials, Chicago, 79 pages (Dec. 1970).

X22. Mine Drainage Abstracts: A Bibliography, Bituminous Coal Research, Monroeville, Penn., (annual supplements, 1967-1974).

23. Munn, R.F., Strip Mining - An Annotated Bibliography, West Virginia Dif University Library, Morgantown, 190 pages. (1973). 
24. Peterson, H.B., and Ralph Monk, Vegetation and Metal Toxicity in

$\checkmark$ Relation to Mine and Mill. Wastes, Circ. 148, Utah Agricultural

$X$ Experiment Station, Logan, 75 pages (Sept. 1967).

25. Ringe, A.C., Land Reclamation in Mining Areas: A Bibliography with Xabstracts, National Technical Information Service, U.S. Department of Xommerce, Springield, Va., 25 pages (Nov. 1973).

26. Sieh1, G.H., Strip Mining: Selected References, 1969-1972, Environmental Policy Division, Congressional Research Service, Library of

Congress, Washington, D..C., (Aug. 1972, revised Jan. 1973).

27. Х , Strip Mining: Selected References 1970-1973, 74-16 EP, Environmental Policy Division, Congressional Research Service, Library of Congress, Washington, D.C., 21 pages (1974).

28. Tompkins, D.C., Strip Mining for Coal: Public Bibliographies No. 4, Institute for Governmental Studies, University of California, Berkeley (1973).

29. Van Alphen, J.G., and Abe11, L.F., Annotated Bibliography on Reclamation and Improvement of Saline and Sodic Soils, (1966-1970), Bibliography No. 6, International Institute for Land Reclamation and Improvement, The Netherlands, 43 pages: (1967).

\subsection{GLOSSARIES AND DICTIONARIES}

30. Bituminous Coal Research, Inc., Glossary of Surface Mining and Reclam$X$ ation Technology, James F. Boyer, Jr., Chairman, Editorial Committee, Bituminous Coal Research, Inc., Monroeville, Penn., 25 pages: (1974).

31. Thrush, Paul W., et al., A Dictionary of Mining, Mineral, and Related ХTerms, U.S. Bureau of Mines, Department of the Interior, Washington, D.C., 1,269 pages (1968). 
THIS PAGE

WAS INTENTIONALLY

LEFT BLANK 


\section{LEGAL ASPECTS OF SURFACE MINING \& RECLAMATION}

32. Beck, R. E., and J. E. Johnson, Legal Aspects of Coal Leasing and Sales and Strip Mine Reclamation in North Dakota, Bulletin No. 22, Cooperative Extension Service, North Dakota State University, Fargo, 8 pages (Dec. 1973).

This informational publication reviews a number of legal considerations related to coal development in North Dakota. Topics discussed are mining leases, mineral deeds, sale of minerals, and reclamation. The goal of the publication is to familiarize readers with important aspects of the sale or leasing of mineral rights and of strip mining and land reclamation. The publication requires a familiarity with legal terminology, but is useful for gaining some knowledge of estate planning, farm leases and partnerships, and the legal aspects of land use problems.

$\aleph_{33}$ Blakely, J. W.,
13 (June 1976).

This article discusses procedures for obtaining a permit to open a surface coal mine. Although it is written in a somewhat light vein, the article points up the bewildering complexity of mine permitting systems.

The article is intended for the general public and for coal company personnel involved in the preparation of mining and reclamation permit applications.

$X_{34}^{-}$

Bosselman, F. P., The Control of Surface Mining: An Exercise in Creative Federalism, Natural Resources J. 9:137-165 (1969).

The main thrust of this article is the need to more clearly define federal, state, and local jurisdictions, and to eliminate overlap and gaps in regulations enforced by various government agencies. Points at which regulations could be directed to control surface mining operations are explored. Problems caused by a detrimental balance of power are discussed and recommendations are made to improve the division of regulatory power. Those not intimidated by legal terminology will find it of value for its suggestions of possible approaches to local control of mining activities.

$\chi_{35}$

Coal Surface Mining and Reclamation: Hearings, Committee on Interior and Insular Affairs, Subcommittee on Minerals, Materials, and Fuels, U.S. Senate, 93rd Congress, Ist Session, U.S. Government Printing X Office, Washington, D.C., 85 pages (Apri1 30, 1973).

36 .

Controversy over Proposed Federal Regulation of Surface Mining of Coal - Pro and Con, The Congressional Digest, pp. 131-160 (May 1974).

37. Fox, R. E., Strip Mining of Coal: A Federal Response to State LegisX Zation, Indiana Law J. 47: 771-787 (Summer 1972).

38. Fritsch, A. J., M. L. Morgan, G. G. Yanik, T. J. Conry, and D. E. Taylor, The Enforcement of Strip Mining Laws in Three Appalachian States: Kentucky, West Virginia, and Pennsylvania, CSPI Energy Series VIII, Center for Science in the Public Interest, Washington, D.C., 110 pages (1975). 
39. Goldberg, E.G., and G. Power, Legal Problems of Coal Mine Reclamation, EPA Report No. 14010 FZO 03/72, prepared by the University of Maryland

X School of Law for the U.S. Environmental Protection Agency, Washington, D.C. (1972).

Coal mining produces a variety of environmental problems -acid drainage, sedimentation, surface subsidence, and surface scars. This study reviews the response of legal institutions to those problems in Maryland, Ohio, Pennsylvania, and West Virginia. Technological and economic concerns are also taken into account.

The study discusses the antecedents of today's Appalachian coal industry and the environmental problems it has created. It examines the way in which the property system allocates rights in coal and coal lands, the efficiency of litigation, present laws and regulations for preventing environmental damage, and constitutional limitations on the ability of the states to effectively respond to these problems. Model legislation giving states the necessary powers to respond to environmental damage is proposed. A case study of the economics of the Maryland coal industry is also presented. The report is legal in tone, but provides valuable information regarding controls and regulations.

40.j Goldberg, E.G., The Legal Framework of Acid Mine Drainage Control, paper presented at the Ohio University Acid Mine Drainage Workshop, Wohto University, Athens (Aug. 2-6, 1971).

41. Ha11, R.E., and William Krutzfeldt, Montona Coal Leasing Practices, Bulletin 1106, Cooperative Extension Service, Montana State Unfversity. Bozeman, 28 pages (1973).

42. Holsten, R.M., Mining Permits -- The Jugular of Mining Operations, i) Third Symposium on Surface Mining and Reclamation, I:12-13, Louisville, Ky. (Oct. 21-23; 1975).

43. Horton, J.0., The imperatives of Interdependence, Fort Union Coal Field Symposium: Proc., Montana Academy of Science, Eastern Montana College, Billings, pp. G-16 to G-22 (April 25-26; 1975).

The paper is a discussion of Federal legislation now pending and its value in environmental pollution control relative to surface mine reclamation. Steps to improve Federal leasing programs are reviewed. Land use study and planning procedures under development are detailed and policy considerations examined. The article is informative regarding future developments in land use planning and reclamation in western coal mining regions.

44. Howard, H.A., Are Landowners Underpaid or Overpaid for. Surface Mining Mineral Rights, The American J. of Economics and Sociology, 30:413420 (1971): 
45. XIssues Reiated to Surface Mining: A Sumary Review with Selected Readings, prepared at request of Henry M. Jackson, Chairman, by George H. Siehl, Committee on Interior and Insular Affairs, U.S. Senate, Pursuant to S.45, a National Fuels and Energy Policy Study, Serial No. 12-10, 92nd Congress, 1st Session, U.S. Government Printing Office, Washington, D.C., 255 pages, tables, illustrations (Dec. 1971).

This is a compilation of reports, documents and articies from government agencies and commercial and private publications. It is intended for congressional use and supplies general information on strip mining. Discussions range from philosophical to technically informative and cover practically the entire nation. The pros and cons of strip mine activities are brought to light by input from organizations such as the Sierra Club and the National Coal Association. State and federal relationships concerning law enforcement responsibility are discussed.

46. Kune, B.R., Strip Mining -- The Construction of Mineral Deed Reservations $X$ and Exceptions, Land and Water Review, 5:97-103 (1970).

47. Lantz, E., Impact of Environmental Requlations on Mining, Mining Congress .J., ○1:48-51 (Nov. 1975).

The author, a representative of the mining industry, discusses the implications (adverse or otherwise) that the National Environmental Policy Act will have on mining, smelting, and refining operations in the United States. He also lists five major elements included in environmental impact statements, discusses the Clean Air Act, and considers the Federal Water Pollution Control Act (as amended).

The author asserts that environmental regulations are generally necessary for national health and well-being; however, he assumes that many regulations are of too little benefit to justify costs, have unattainable goals, need a reappraisal of objectives and were created without allowing sufficient time for study.

This article would be of interest to environmental planners and interested citizens. It is not technical, and presents some interesting arguments.

48
48 Legal Study of Coal Resources on Public Lands, prepared for the Public Land Law Review Commission by the University of Utah College of Law, Salt Lake City (1968).

49. Mackleston, Sandra, Strip Mining Reclamation Requirements in Montana -UA Critique, Montana Law Review, 32:65-79 (Winter 1971).

50 Malin, H.M., Jr., Feds Eye Regulations for Strippers, Environmental Science and Technology, 6:27-29 (Jan. 1972).

51. Manning, H.C., Mineral Rights versus Surface Rights, Natural Resources L Lawyer, 7:194-224.(1967). 
52. Markey, T.R., Construction of Deeds Granting the Right to Strip Mine,

University of Cincinnati Law Review, 40:304-318 (Summer 1971).

53. Mason, G.J., Surface or Mineral: A Single Test?, Baylor Law Review,

23:407-418 (Summer 1971).

54. Master, D.L., The Regulation of Surface Mining: A Report on the

$\checkmark$ Pending National Legislation, mimeo report, Federation of Rocky Mountain

$X$ States, Denver, 12 pages plus appendix (1973).

55. McCutcheon, K.C., The Common Low Rights to Subjacent Support and Surface

X Preservation, Missouri Law Review, 38:234-256 (Spring 1973).

X56. Mineral and Mining Lows of Wyoming, 2nd Ed., Geological Survey of Wyoming, Laramie (Oct. 1973).

The Geological Survey of Wyoming compiled this document to provide a condensed semiofficial source of information on the state's mineral and mining laws. Of the Acts and provisions, approximately one-third concern the state mine inspector, aeronautics in relation to surveying and prospecting, agriculture, and public lands. The inclusion of this variety of provisions is necessary to provide information on areas of conflict that arise in seeking mining permits and during mine operation. The Wyoming Environmental Quality Act is included; pertinent to mining are tough bonding and penalty clauses in rogard to land reclamation procedures, which are submitted with permit applications for review. In the event of failure of mine operators to restore lands, bond forfeiture provides funds for a state-backed reclamation effort. Permitting requires submission of a mining and reclamation plan (to suit future use), and advance public notice to allow tine for the filing of written objections by affected parties.

X57. One Third of the Nation's Land; A Report to the President and to the Congress by the Pubiic Land Low Review Commission, Washington, D.C., 342 pages (1970).

58. Power, T.M., Federal Regulation of Strip Mining: Doubtful Protection, Montana Business Quarterly, 11(3):21-25 (1973).

59. Preate, E.D., Jr., A New Land for an OZd Problem, Appalachia, 5:41-53 (Feb.-March 1972).

X60. Providing a Temporary Moratorium on Federal Coal Leasing in the State of Montana; Report Together with Minority Reviews to Accompany S. 377, Committee on Interior and Insular Affairs, U.S. Senate, 92nd Congress, 2nd Session, Senate No. 92-1284, U.S. Government Printing Office, Washington, D.C., 6 pages (1972).

X61. Providing for the Regulation of Strip Mining, for the Conservation, Acquisition and Reclamation of Strip Coal Mining Areas, and for other Purposes; Report Together with Separate Views to Accompany H.R. 6482, Committee on Interior and Insular Affairs, House of Representatives, 92nd Congress, 2nd Session, Report No. 92-1462, U.S. Government Printing office, Washington, D.C., 6 pages. (1972). 
62. Pyles, H.L., What's Ahead for Our Public Lands, Natural Resources Council if of America, Washington, D.C. (1970).

63. Regulation of Strip Mining: Hearings, Committee on Interior and Insular Affairs, House of Representatives, 92nd Congress, 1st Session, H.R. 60 and Related Bills, U.S. Government Printing Office, Washington, D.C. 890 pages, Hearings 9/20-11/30/71 (1972).

64. X Regulation of Surface Mining: Hearings, Committee on Interior and Insular Affairs, House of Representatives, 92nd Congress, 1st Session, H.R. 3 and Related Bills, U.S. Government Printing Office, Washington, D.C. 2 Vols., Hearings 4/9-5/15/73 (1973).

65. Xegulation of Surface Mining Operations: Hearings, Committee on Interior and Insular Affairs, U.S. Senate, 93rd Congress, 1st Session, on S.425 and S.923, U.S. Government Printing Office, Washington, D.C., Part I, 865 pages, Part 2, pp. 867-1410 (March 13-16, 1973).

66. Reitze, A.W., Jr., Old King Coal and the Merry Rapists of Appalachia, Case Western Reserve Law Review, 22:650-737 (1971).

67X Enviromental Law, 2nd ed., North American International, Washington, D.C. (1972).
Resources, North American International, Washington, D.C. (1974).

Chapters 12 and 13 discuss surface mining and mineral resources conservation. Background material on the various types of surface mining and their effects is supplied as a preliminary for more extensive coverage of strip mining laws and the ongoing legal battle between conservation forces and the surface mining industries. The roles of state and local governments are investigated, as are state reclamation laws, their effectiveness and the costs they impose upon mine operators. Federal laws, various proposals of which are reviewed in the text, are to provide uniform regulations and enforcement.

The Ohio Strip mining law is presented in full and analyzed at length. Conflicts in the use of broad-form deeds for mineral and surface rights, and their resolution by various state governments, are discussed and landmark court decisions are reviewed. In Ghapter 13, procedures for staking a mineral claim on public lands are outlined in a question-and-answer format. The location patent system is suggested as an answer to deficiencies in the General Mining Law of 1872.

Extensive legal histories on oil shale development and Alaskan pipeline construction delve into the use of the courts, and power moves made by the involved parties. This volume is valuable for its exposition of current laws, their underlying principles, and its presentation and analysis of evolving legislative trends. It is intended for use by planning and resource management professionals who may not have formal legal training. 
${ }^{69}$ Renkdy, L.E., Local Zoning of Strip Mining, Kentucky Law J., 57:738-755

(1969).

70. Salmen, L.J., D.L. Master, and E.J. Hoffman, A Two-Phased Coal S.trip Mining Pilot Study: Phase I, The Effect of Legislative Slope Restrictions

X on Strip Mining Operations; Phase II, Determination of the Critical

$X$ Factors Affecting Reclamation Success and Costs, Federation of Rocky Mountain States, Denver, 15 pages plus figures and appendix (1973).

71. Scholenberger, Albert, Sale of Coal Leases: Rules and Regulations, $\checkmark$ North Dakota State Land Commission, Bismarck (1972).

72. Schneider, D.A., Stmip Mining in Kentucky, Kentucky Law J., 59:652-672 X. (1971).

73. Siehl, G.H., Legislative Proposals Concerning Surface Mining of Coal, prepared for Committee on Interior and Insular Affairs, U.S. Senate, U.S. Government Printing Office, Washington, D.C. 25 pages (1971).

\74. Con, Library of Congress, Lined Land Reclamation Requirements Pro and D.C., 41 pages (1968).

$\chi 75$. , Mined Land Reclamation Requirements: Issues, Options, and Arguments, Environmental Policy Division, Congressional Research Service, Library of Congress, Washington, D.C., 45 pages (April 18, 1968, rev. April 24, 1975).

X76. State Regulation of Strip Mining, State Legislative Research Council, Pierre, South Dakota, 47 pages (1970).

77. Stewart, C.L., Strategy in Protecting the Public's Interest in Land: with Special Reference to Strip Mining, The J. of Land and Public Utility Economics, 15:312-316 (1969).

78. Stewart, R.E., Jr., (ed.), Conference on Property and Mineral Rights, Interim Report No. 2, Little Missouri Grasslands Study, North Dakota State University, Fargo (1973).

X79. Summary of State Strip Mining Lows, National Coal Association, Washington, D.C. (1969).

X80. Surface Mining - Hearings Pursuant to S.45: A National Fuels and Energy Policy Study, Committee on Interior and Insular Affairs, U.S. Senate, 92nd Congress, 1st Session, Senate No. 92-13, on S.2777 and S.3000, U.S. Government Printing Office, Washington, D.C., Part 3, pp. 883-1173 (Feb. 24, 1972).

X81. Surface Mining Reclamation Act of 1973, Report to Accompany S.425, Committee on Interior and Insular Affairs, U.S. Senate, 93rd Congress, 1st Session, Senate No. 93-402, U.S. Government Printing Office, Washington, D.C., 94 pages (1973). 
82. Tillotson, I.M., Legal Principles of Property Boundary Location on the Ground in the Public Land Survey States, University of Montana.Press, Xissoula (1974):

83. Wicks, Gary, et a1., A Look at Coal-Related Legislation, Montana $\checkmark$ Business Quarterly, 11(3):5-15 (1973). 
THIS PAGE

WAS INTENTIONALLY

LEFT BLANK 
84. : Agria, S.R., Special Tax Treatment of Mineral Industries, in A.C. Harbeger and M.J. Bailey (eds.), The Taxation of Income from Capital, Washington, D.C. (1969).

85. Bitler, J.R., and R.J. Evans, Coal Surface Mining Reclamation Costs Appalachion and Midwesterm Coal Supply Districts, paper presented

before the Third Symposium on Surface Mining and Reclamation, Louisville, Ky., II:58-64 (Oct. 21-23, 1975).

86. X Coal Surface Mining Reclamation Costs Appalachian and Midwestern Coal Supply Districts, Information Circ. 8695, Bureau of Mines, U.S. Department of the Interior, Washington, D.C., 1975, 50 pages.

This study performed by the U.S. Bureau of Mines, arrived at the following conclusions:

1. Costs expressed in dollars per ton are a more practical measure than those expressed in dollars per acre.

2. The most significant cost differences resulted in comparisons on the basis of mining method. Greater costs are associated with contour mining methods. Greater costs are associated with contour mining ( $\$ 3.01 /$ ton average) than with area mining ( $\$ 1.73 /$ ton average).

3. Comparisons by region and size of mining operation did not reveal significant differences.

4. The greatest costs (95\%) are for backfilling. Premining planning and revegetation account for only a small portion of overall reclamation costs.

This report is well written and provides an authoritative view of Appalachian and Midwestern reclamation costs. Data are analyzed in terms of mining methods, equipment utilization, backfilling methods and revegetation techniques. Some knowledge of statistical analysis and mine operations is helpful to derive maximum benefit from this paper. However, it is valuable in providing an overview of costs associated with the various aspects of surface coal mine reclamation.

87. Boyce, Thomas A., Economic System Analysis of Large-Scale Surface Coal Mining, paper presented before the Third Symposium on Surface X Mining and Reclamation, Louisville, Ky., II:65-79 (Oct. 21-23, 1975). 
This paper is a progress report in the development of a compputerized modeling system designed to analyze the economic and technical aspects of large surface coal mines. The system is intended to provide an initial appraisal of mining system efficiency and coal costs under various operating conditions. The developers envision it as a tool for mine planning in order to develop an efficient operating system for surface mining and reclamation in large-scale mines supplying coal conversion facilities. The paper is technical in nature, but comprehensible to those with a minimum background in systems modeling for environmental planning.

88. Boyle, J.R., Waste Disposal Costs of a Florida Phosphate Operation, Information Circ. 8404, Bureau of Mines, U.S. Department of the Interior, Washington, D.C., 1969, 24 pages.

89. Brock, S.M. and D.B. Brooks, The Myles Job - A Study of Benefits and Costs of Surface Mining for Coal in Northern West Virginia, Research W Series 1, Appalachian Center, West Virginia University, Morgantown, 61 pages (1968).

90. Brooks, D.B., Strip Mine Reclamation and Economic Analysis, Natural Resources J., 6: 13-44 (1966).

Advocating a cost-benefit approach to strip mine reclamation, this article studies the interaction of three basic goals involved in what the author considers an economic undertaking: (1) national productivity, (2) quality of the environment, and (3) local employment. Public policy becomes the compromise between social benefit and minimum acçeptable costs; it provides a possible framework for establishing regulations. This publication gives an economic overview of reclamation.

91. Bush, J.M., The Effect of Taxation on Mine Management, The Valuation of $0 i l$ and Mineral Rights, International Association of Assessing Officers, Chicago, pp. 75-83 (1972).

X 92. Coal Surface Mining and Reclamation: An Environmental and Economic Assessment of Alternatives, Report to the Committee on Interior and Insular Affairs, U.S. Senate, Council of Environmental Quality, Executive Office of the President, Washington, D.C., Pursuant to S. Res.45, A National Fuels and Energy Policy Study, Serial No. 93-8 (92-43) (March 1973).

This study contains a general description of surface mining techniques, predominantly those used in the Appalachian area. The potential environmental and economic impacts of slope angle restrictions on contour strip mining are discussed and analyzed. The benefits of concurrent mining and reclamation are highlighted, with an emphasis on premining planning of the overall mining and reclamation operation State regulatory programs are outlined by state and administrative agencies. : Enforcement programs are examined in terms of relative effectiveness. the impact of slope angle restrictions on coal production and regional economics is analyzed in detail, with a scenario developed for a $20^{\circ}$ slope angle restriction. The main area of concern 
in this study is with the effects of contour strip mining on steep slopes in the Appalachian area with its concommitant adverse environmental effects of the past and present.

Appendices include a breakdown of the environmental effects of strip mining and reclamation, soil stability and landslide potential, costs of reclaiming orphaned land, cost analyses of contour mining and concurrent reclamation, highlights of state regulations pertaining to surface mining of coal, and an analysis of the impacts of slope angle restrictions in terms of occupational health and safety.

Cost Analysis of Model Mines for Strip Mining of Coal in the United States, Bureau of Mines. Information Circ. 8535, U.S. Department of the Interior, Washington, D.C., 116 pages (1972).

94. DeMoss, E.C., Economics Associated with New Designs and Larger Equipment X in Mining - Stripping, Mining Congress J., p. 43 (Nov. 1972).

95. Dreese, G.R., and H.L. Bryant, Costs and Effects of a Water Program for a Small Stripping Company - Southeasterm Ohio, Water Resources

X Bulletin, 8:320-327 (April 1972).

96. Energy, Economics, and Our Environment, Virginia Surface Mining and Reclamation Association, Norton, 18 pages (1973).

97. Foreman, J.W., D.F. Carlin, E.A. Nephew, and R.L. Spore, The Costs of Coal Surface Mining and Reclamation in Appalachia, paper presented

X before the Third Symposium on Surface Mining and Reclamation, Louisville, Ky., II:119-130 (Oct. 21-23, 1975).

This is an analysis of data obtained from 40 model surface mines, utilizing a variety of mining techniques and approaches to reclamation. Costs are analyzed in terms of unit operation costs and total costs. Rate-of-return analyses were performed in each case. Quality of reclamation achieved was divided into three classes: (1) Basic; (2) Intermediate; and (3) Full Reclamation. This division was based on analysis of such variables as spoil stabilization, type of backfilling, success of revegetation and erosion control, and aesthetics. The report is highly technical and requires a substantial background in economic analysis or surface mine operations for a full understanding of the material presented.

98. Foreman, W.E., Impact of Higher Ecological Costs and Benefits on Wurface Mining, paper presented at American Mining Congress 1976 Coal Show, Detroit (May 10-13, 1976).

This report outlines a computer program used for calculating cost of reclamation of surface mining. An extensive literature review was done with the objectives of understanding the process and types of recommended plantings and procedures used to restore surface mined lands; costs associated with restoration of surface mined land; and laws that regulate restoration of surface lands in Kentucky, Pennsy1vania, Virginia, and West Virginia. 
This report is intended for those persons involved with mining and reclamation with a background in cost/benefit analysis and/or computer technology.

99. Gaffney, Mason, (ed.), Extractive Resources and Taxation, The University $X$ of Wisconsin Press, Madison, 446 pages (1967).

100. Gillespie, Marie, Coal Mining Taxes in Montana, Montana Business Quarterly, Bureau of Business and Economic Research, University of

X. Montana, Missoula, 12(1):23-26 (Winter 1974).

101. Greenbaum, M.E., and C.E. Harvey, Surface Mining, Land Reclomation, 9 and Acceptable Standards, UKY TR 83-74-1MMR3, University of Kentucky, Lexington, 40 pages (June 1974).

This report is an analysis of the present performance-bond system utilized by most states to insure proper reclamation of strip mined 1and. Policy implications of the system are examined, and regulation is presented as an alternative measure. The report is in response to proposed legislation that would impose a reclamation tax that the authors feel would conflict with the need to provide a continuous flow of energy resources. It is shown that a performanc bond can be tailored to encourage concurrent rather than postmining reclamation. The impact of the internalization of external cost are discussed in depth, with a comparison based on two control policies. A static model of production functions and externality generation is presented in the form:

$$
x_{h}=f\left(k_{x_{h}}\right) \text { where } f_{k_{x_{h}}}, f_{1_{x_{h}}}>0
$$

The report assumes a working knowledge of partial differential equations, and requires careful reading to understand the author's reasoning.

102. Haley, M.J., (ed.), Economic Priorities Report - A Study of Public and Indian Coal Leasing in the West, Council on Economic Priorities, New York, 84 pages (May 1974).

103. Herfindahl, 0.c., Some Fundamentals of Mineral Economics, Land Economics, 7 31:131-138 (May 1955).

104. Holland, C.T., The Value of Coal in the Ground, The Valuation of Oil. and Mineral Rights, International Association of Assessing Offices, Chicago, pp. 42-72 (1972).

105. LaFevers, J.R., A Cost and Benefit Analysis of the Reclamation of

5 Land Surface Mined for Coal in Vigo County, Indiana, Ph.D. dissertation, Indiana State University, Terre Haute (Aug. 1974).

106. Lockner, A.0., The Economic Effect of the Severance Tax on the Decisions of the Mining Firm, Natural Resources J., 49:48-53 (April 1963). 
107. Nephew, E.A., and R.L. Spore, Costs of Coal Surface Mining and Reclamation in Appalachia, ORNL-NSF-EP-86, prepared for National Science Foundation, by Oak Ridge National Laboratory, Oak Ridge, Tenn., 45 pages (Jan. 1976).

108. Otte, J.A., and Michael Beohlje, A Model to Analyze the Costs of Strip Mining and Reclomation, paper presented before the Third Symposium on Surface Mining and Reclamation, Louisville, Ky., II:80-98 (Oct. 21$23,1975)$.

The purpose of this paper is to describe a user-oriented computer program for calculating the cost of mining and reclamation with various materials handling techniques and procedures in different pit configurations. Sections II and III of this paper provide a basic overview of the strip mining process and problems encountered along with a mining cost program with emphasis on input data and procedures.

The latter sections of this paper present illustrative results from the analysis of pan scrapers in various pit configurations along with a summary of the study.

This paper assumes some knowledge of coal mining with a background in computer programs.

109 Pundari, N.B., and J.A. Coates, Estimate of Reclamation Costs Resulting from Federal Low, Coal Age, 80:129-131. (April 1975).

110. Robinson, N., Capital and Operating Costs at New Coal Mines, Mining JCongress J., p. 80 (Jan. 1969).

111X skelly \& Loy, Engineers - Consultants, Economic Engineering Analysis of U.S. Surface Mines and Effective Land Reclamation, Bureau of Mines, Washington, D.C. (Feb. 1975).

Coal strip mining in the U.S. is investigated by dividing the country into four regions, each of which is distinguished by generalized mining methods that are shaped by the terrain of the region. Region I extends from eastern Kentucky through Virginia and is characterized by steep slope mining methods, such as head-of-hollow-fill and mountain top removal. Region II extends from Pennsylvania through Alabama. Region III has gentler slopes than Region II and employs modified block cut area mining. The same mining methods are employed in Region IV, extending from Arizona to Montana, but the area is distinguished by its semiarid to arid.climate, thick coal seams, and shallow overburden. Full description of the mining and associated reclamation techniques are offered. Graphic displays of the economies of equipment combination are highly interesting and valuable to a systems analytic approach to mine planning, involving linear programming. This is a technical document with a wealth of facts and figures on the economic and engineering aspects of mine operations. A mining engineering background is required in order to derive maximum benefit from the data presented. 
112. Smith, V., The Economics of Production from Natural Resources, American Economic Review, 58:409-431 (June 1968).

113. Spore, R.L., The Economic Problem of Coal Surface Mining, Environmental 5 Affairs. 2:685-693 (Spring 1973).

X114. Surface Mining, Extent and Economic Importance, Impact on Natural Resources, and Proposals for Reclamation of Mined Lands, Proc., Conference on Surface Mining, Roanoke, Virginia, R.M. Publication 369, Council of State Governments, Lexington, Ky., 64 pages (1964):

115. Sweeney, J.W., and R.N. Hasslacher, The Phosphate Industry in the

Southeastern United States and its Relationship to World Mineral
Fertilizer Demand, IC 8459, U.S. Bureau of Mines, Department of Interior,
76 pages (1976). 76 pages (1976).

116. Treacy, J., and R. Overton, Measuring Extemalities of Strip Coal Mining via Property Tax Assessments, Extraction of Minerals and Energy:
Today's Dilemmas, Ann Arbor Science Publishers, Inc., Ann Arbor, Mich., (n.d.).

The difficulty in measuring the costs to society resulting from strip mining has long been recognized. This paper suggests that a medium for measuring the effect of strip mining on a locality exists in the tax valuation assessment process. A mathematical method of measuring external costs associated with strip mining is developed and tested on data from counties in the state of Ohio.

This publication is not technical, but an understanding of basic economics and statistical procedures would be helpful for complete comprehension.

117. Van Lanen, J.L., R.J. McConnen; and L.S. Thompson, Estimated Impact

Tax Revenues and Coal Production of Severence Taxes on Montana Coal, Department of Agricultural Economies and Economics, Montana State University, Bozeman (1973).

118. Watts, M.J., Estimated Costs of Spoiz Bank Reclamation AZternatives, Staff Paper 75-24, Department of Agricultural Economies and Economics, Montana State University, Bozeman, M.Sc.thesis, 124 pages (Dec. 1975).

This thesis contains detailed cost analyses for spoil bank reclamation alternatives applicable to eastern Montana. Mathematical derivations are presented in appendices. The work is highly technical and requires an understanding of applied economics. 
X119. Allen, Natie, Jr., Experimental Multiple Seam Mining and Reclamation on Steep Mountain Slopes, paper presented before Applied Technology Symposium on Mined-Land Reclamation, Pittsburgh, Penn. (March 7-8, 1973).

This is a report of a study conducted by TVA's office of Engineering Design and Construction on the simultaneous mining and Y reclamation of three coal seams using a modified multiple strip method. A modified block-cut method was utilized with mining beginning on the lower seam first. No more than one mile of this was mined before stripping began on the upper seams. Thus, spoil could be pushed into the lower cut when conditions demanded to reduce handling costs. As areas were completed and graded, final dressing included leaving of roadways for haulage and future access to the site. Revegetation was begun on the dressed slopes as soon as possible to cut down on erosion problems. Although currently incomplete, efforts are being made to make reclamation more cost-effective by reducing the cost of spoil hauling and placement. The paper presents a method of mining and reclamation largely applicable to Appalachian contour mining and is technically oriented.

X120. An Appraisal of CoaZ Stmip Mining, Tennessee Valley Authority, Knoxville, Tennessee (Feb. 1963).

X 121. Bariy, Theodore, and Associates, Operations Study of Selected Surface Coal Mining Systems in the U.S., Open-File Report No. 72-75, Bureau of Mines, U.S. Department of the Interior, Washinginn, D.C., 236 pages, (Feb. 1975).

The overall objective of this study was to gather operational data from selected surface coal mining systems in the United States, and to assess the potential productive and economic capacity of the systems. The study included four mines, each using different mul.1ng techniques and equipment. The mines were selected from each of the major coal fields: midwestern, eastern, northwestern, and southwestern. Following the documentation of each operation and development of a comprehensive production and cost data base, an analysis was conducted to identify production inefficiencies and to develop shortterm and long-term improvements that would increase the mines' productivity or reduce costs. Short-term improvements were limited to solutions that could be achieved with the existing mining system. Long-term improvements 1dentified major production bottlenecks or inefficiencies that could only be corrected through imposing long lead-time solutions, such as major changes, to the mining system or major capital expenditures.

Although a technical operations study, this report is valuable in providing insight into the problems faced in the design of surface mine systems and the constraints of equipment and site conditions within which an operator must work. However, a good background in surface mining management is required for more than a superficial understanding of the material presented. 
122. Blakely, J.W., Surface Mining in AppaZachia, Coal Mining and Processing, $11(6): 36-39$ (June 1974).

123. Brealey, S.C., Groundwater Control in Opencast Mining, Proc. of Symposium on Opencast Mining, Institute of Mining and Metallurgy, London, pp. 390415 (Nov. 1964).

124. Breslin, J.J., and Richard J. Anderson, Observations on the Surface Mining of Coal, Battelle Energy Program Report, Battelle Memorial Institute. Columbus. Ohio (1974).

In obtaining a state-of-the-art report on the surface mining of coal, the Battelle Mining Workshop Team visited 16 wel1-managed and we11-planned mines, three of which were located in Germany. Physical conditions that influence the selection of the type of strip mine operation (either area, contour, or open pit mining) are discussed. Also examined are economics of reclamation for each of the three modes of mine operation as affected by the geology, hydrology, and climatic condition of individual sites. Special attention is given to modern heavy equipment used in excavation and haulage. German operations were seen to be especially efficient using the bucket wheel excavator, rail, and eonveyor systems, but were found to be generally inapplicable to American surface mining operations. German plans call for doubling the size of their BWEs, while findings here suggest that American excavators have already exceeded optimum size. As for reclamation, in western mines, it is reported that soil must be weathered for three years in order to support vegetation. The reclamation of contour mines is reported to be difficult with present equipment. Numerous references are made to Ohio's strip mine law. Well illustrated and highly informative, this report has a broad scope and is valuable in providing up-to-date information to those involved in the planning, legal, or reclamation aspects of surface mining.

125. Buturla, F.J., and Tinstman, R.A., Multiple Lift Stripping, Mining. W Congress J., p. 55 (Oct. 1970).

126. Campbel1, R.A., Multiple Secon Surface Mining, Mining Congress J., p. 71 (Aug. 1970).

127. Cassidy, S.M., (ed.), Elements of Practical Coal Mining, American Institute of Mining, Metallurgical and Petroleum Engineers, New York, 614 pages, (1973).

128. Chironis, N.P., In West Virginia HizZs. . It's Haulback Mining AlZ the Way, Coal Age; 79:60-64 (Nov. 1974).

This informative article describes the method of haulback mining in West Virginia. The advantages and disadvantages of haulback mining are discussed in relation to conventional contour strip mining. A case study of the Princess Susan operation in West Virginia is used to clarify the finer points of this article.

This article is intended for the surface mine operator, whose knowledge of strip mining would allow for better comprehension of the concepts discussed. 
129. Coal Age, Innovative Earthmoving Tools Make $P$ \& M Coal Rectamation Project More Economical, pp. 76-79 (Nov. 1975).

This report discusses three earthmoving tools used in economically moving spoil piles during the mining process. The Pittsburgh \& Midway Coal Mining Company $(P \& M)$ devised a method using two $D 9$ tractors to move some 6000-8000 cu. yd. of spoil per hour at reasonable cost levels. $P \& M$ also has two additional pieces of equipment: a 24-ft wide $V$ plow that makes the initial cuts at the peak of each crest, and a $24-\mathrm{ft}$ wide grading bar that mounts onto the dozer blade of a D8 crawler tractor. Together, these three earthmoving tools provide for an economical method in moving spoil piles.

This report is intended for surface mine operators and thus assumes a working knowledge of coal mining equipment.

Coal Age, Surface Mining and Reclamation, pp. 265-2.74 (ilidMay 1975).

Steepness of slope is a major problem in the surface mining of coal in Appalachia. New federal and state surface mining laws have stimulated improved surface mining methods and reclamation techniques. Controlled placement operations (including haulback, flat-top or mountain top removal) and longwall stripping have largely been developed as a response to new environmental laws.

In this article, the author defines "controlled placement" and examines water retention techniques, haulback methods, and mountain top removal. Longwall stripping and multipe-seam mining are also discussed. The author describes a haulback mining operation in eastern Ohio which is planned to "return the land to better-thanoriginal condition." A modified block-cut method that is used in southwestern Pennsylvania is also examined.

Included in the publication are several informative figures that diagram a haulback operation, experimental multiple-seam mining, a modified block-cut, a plan view of a longwall stripping system, and a coal reclaiming operation that uses a dredge. The West Virginia strip mining law (amended in 1971) is also highlighted.

This article is very informative in regard to reclamation techniques that are used in Appalachia. The language is not technical, but an understanding of surface mining operations and reclamation methods would be helpful for complete comprehension.

131. Conne11, J. P., Horizontal Haul Methods, A Cost Effective Method of Mining Multiple Coal Seams, Third Symposium on Surface Mining and Declamation, Louisville, Ky., II:99-118 (Oct. 21-23, 1975).

132 Cornforth, C.L., Reclamation Forges Ahead Throughout the Land, Coal X Mining and Processing, Vol. 12 (Jan. 1975). 
$X_{133}$ - Farming for Profit on Reclaimed Land, Coal Mining and Processing (Aug. 1971).

X 134. - Alabama Operators Organize for Better Reclamation, Coal Mining and Processing, 11(7) (July 1974).

135. Reclamation Commitment Proves Rewarding, Coal Mining and Processing, 10:32-36 (March 1973).

136. Custred, V.K., New Mining Methods Rehabilitate Florida's Strip Mines, Mining Engineering, 15(4):50-52 (Apri1 1963).

X

This article discusses premine planning as a new method of land rehabilitation.. In a phosphate mining area of Florida, methods to reclaim the strip mined land were analyzed. Because of the high groundwater table in the area, surface mining operations resulted in man-made lakes. Therefore, premine planning was instituted to regulate the location of these lakes.

This article is intended for surface mine operators and assumes a knowledge of surface mining techniques for full comprehension.

137. E1der, J.L., and Kube, W., (compilers), Technology and the Use of Lignite: Proceedings, Bureau of Mines - University of North Dakota Symposium, Bismarck, April 20-30, 1965, Information Circ. No. 8304, Bureau of Mines, U.S. Department of the Interior, Washington, D.C. (1966).

138. Falkie, T.V., A Survey of Current Open Pit Practices in Florida 'Phosphate, Case Studies of Surface Mining, H.L. Hartman, ed., American Institute of Mining, Metallurgical and Petroleum Engineers, Inc., New York, pp. 248-257 (1969).

This article is a summary of mining and benefication practices peculiar to phosphate mining in central Florida. Waste disposal and reclamation problems unique to the industry are briefly discussed, particularly those relating to the reclamation of processing-slimes ponds. These represent the greatest problem in land reclamation due to the fineness of colloidal material and the difficulty of dewatering the slimes in order to stabilize them. The article assumes some prior knowledge of surface mine operations for understanding.

X139. Flexible Mountaintop Surface Mining, Harburly Mine, Caperton Coal Compony, Coal Age 69:118-121 (April 1964).

140. Forrester, J.D., Proceedings of Symposium on Surface Mining Practices, $\checkmark$ College of Mines, University of Arizona, Tucson, 131 pages (1960).

141. Fuller, J.A., and Ruby, G.R., Selection of Stripping Equipment, Mining Congress J. (Oct. 1965).

142. Green, J.W., Stabilization of Strip Mine Haulage Roads, American Road $\chi$ Builder Association Meeting, Dallas (Jan. 1959). 
143. Gulf Oil Corp., The New Look of Blasting, Gulf Oil \& Chemical Co., Blasting Materials Div., 3435 Broadway, Kansas City, Mo. (1967).

144. Hagen, H.D., Special Problems and Aspects of Surface Mining in AZabama, Third Symposium on Surface Mining and Reclamation, Louisville, Ky.,

D I :13-15 (Oct. 21-23, 1975).

145. Haley, W.A., Changing Methods and Equipment Use in Appalachian Surface Coal Mining, paper presented before the Second Research and Applied

Technology Symposium on Mined-Land Reclamation, Louisville, Ky., pp. 193-203 (Oct. 1974).

The advent of stringent state reclamation laws is having a pronounced effect on traditional contour mining procedures. Some new methods that have resulted are haulback, block-cut, and valley fill. Costs involved in these methods are estimated, using typical equipment spreads and a set of assumptions on mine working conditions. Charts show that though overburden handling costs are approximately double for new methods, total mine costs increased almost a third. As energy demands continue to grow, the author feels that price increases will offset these costs. The article contains much that is of value in the estimation of costs for planned reclamation efforts, but assumes a working knowledge of surface mining and reclamation practices.

146. Hartman, H.L., (ed.), Case Studies of Surface Mining: Proceedings of the 2nd International Surface Mining Conference, Minneapolis,

Xeptember 18-20, 1968, American Institute of Mining, Metallurgical, $X$ and Petroleum Engineers, Inc.; New York, 322 pages (1969).

The case studies focus on engineering and management problems. and decision-making in the development and operation of strip, openpit and placer mines, worldwide. Various commodities, such as coal, iron ore, copper, industrial minerals, and other metals are included. A knowledge of surface mine operations and management is hblpful in understanding the information presented in this volume. It is intended for students and practitioners of surface mining with a working background in mine operations.

147. Heine, W.N., A New Method of Surface Coal Mining on Steep Terrain, $X$ papers presented before Research and Applied Technology Symposium on Mined-Land Reclamation, Pittsburgh, Penn., pp. 105-116 (March 1973).

The Mears Coal Company worked with the Pennsylvania state regulatory agency responsible for the permitting of mining to develop a technique that would allow for recovery on steeper than normally permitted slopes (over $20^{\circ}$ ). The block-cut method was modified to incorporate reclamation concurrent with recovery operations. A box cut was made at the middle of the lease and spoil deposited as fill in a topographic depression. Spoil from susequent cuts was deposited in the initial cut and mining continued, with spoil moving from the working area into previous cuts. Acidic material was buried along the highwall and $25 \mathrm{ft}$ of outcrop left along the outslope to prevent drainage of acid water. Grading and revegetation followed immediately after mining, 
cutting down on the amount of spoil handling and on erosion from ungraded slopes. Siltation problems in nefghboring streams were dramatically reduced and cover established the first year after mining. Tie method was found to be very competitive with other surface mining methods in use in the Appalachian area, particularly since only standard earthmoving equipment was used for all operations. The report is technical in nature and assumes a working knowledge of surface mining, but is useful in terms of reclamation planning.

148. Hopper, W.H., Surface Mining of Coal, Mining Congress J., p 76

U (Feb. 1969).

149. Jackson, D., Jr., Plateau Strip Mining in AppaZachia, Coal Age, 73:90-95 (Aug. 1968).

150. Jasper, D., Surface Mining and Reclamation of the Stearms \#2 Coal in

South-central Kentucky, Third Symposium on Surface Mining and Reclamation, Louisville, Ky., I:237-241 (Oct. 21-23, 1975).

151. Johnson, Craig, Practical operating Procedures for Progressive Rehabizitation of Sand and Gravel Sites, National Sand and Gravel Association, Silver Spring, Md. (1966).

152. Kachanowsky, B.J., The Coal Stripping Operation, Coal Mine Spoil Reclamation: Scientific Planning for Regional Beauty and Prosperity, Proc., School of Forest Resources Symposium, October 12-13, 1965, School of Forest Resources, College of Agriculture, Pennsylvania State University, University Park, pp. 77-81 (1965).

153. Knight, H.E., Strip Mining Review of 1971, Mining Congress J., pp.-39-43 SN (April 1972).

154. LaFevers, J.R., Some Effects of Legislation on Equipment Needs in the Reclamation of Surface Mined Land in the Midwest, Paper No. 750582, $\checkmark$ Society of Automotive Engineers, Warrendale, Penn. (April 1975).

156. Mathematica, Inc., Draft Final Report on the Design of Surface Mining Systems in Eastern Kentucky, 2 Vols. Mathematica, Inc., Princeton; N.J., for Ford, Bacon, and Davis, Inc., New York (April 1973).

157. McFadden, Damon, Pit Planning and Design -- Coal Mines, Surface Mining,<smiles>[Y]C1(C)CC1</smiles>
Eugene P. Pfleider, (ed.), Seeley W. Mudd Series, American Institute of Mining, Metallurgical, and Petroleum Engineers, New York, pp. 211-223 (1968).

This report analyzes the planning and design of coal mine pits with particular emphasis on quantitive measurements, overburden removal, and geographical factors affecting surface mining. Single seam and multiple seam operations are briefly discussed, along with selection of optimum design plans. 
Knowledge of open-pit mining techniques will allow for better comprehension of this article.

158. Meigh, A.C., and D.J. Henkel, Application of Rock and Soil Mechanics to Surface Mining, Proc. Symposium on Opencast Mining, Institute of

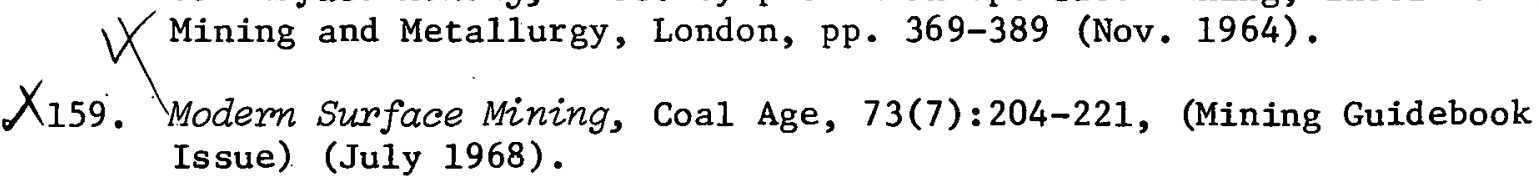

160. Nolden, C., Big Constmuction Signifies Growth at $P$ \& $M^{\prime}$ s New Mexico Mine, Coal Mining and Processing, 13(6) (June 1976).

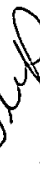

This article gives an overview of how a change in equipment and techniques can result in an increase in production rates. The Pittsburgh and Midway's mining operation in New Mexico has predicted a move from a 1976 production rate of 500 thousand to $5 \mathrm{mfllion}$ tons annually by 1980. The rate of this increase will be the result of such discussed equipment changes as: using four 55-cu-yd draglines instead of one small shovel, and operating with more 100 ton coal haulers and overburden drills.

The area's topography along with plans for land reclamation are discussed. The author assesses $P \& M^{\prime} s$ land reclamation program, which, through spoil manipulation, is being tried to enhance revegetation.

This article assumes knowledge of mining operations and equipment in order for the reader to gain maximum benefit from its contents.

161. Pfleider, E.P., (ed.), Surface Mining, Seeley W. Mudd Series, American Institue of Mining, Metallurgical and Petroleum Engineers, New York, 1061 pages (1968).

162. Phillips, G., Use of the Wheel Excavator - Possible Application to Spoil Bank Rehabilitation, Technology and Use of Lignite, edited by. J.L. Elder and W.R. Kube, Information Circ. 8304, Bureau of Mines, U.S. Department of the Interior, Washington, D.C., pp. 116-121.(1966).

163. Ramani, R.V., M.R. Ferko, and R. Stefanko, Surface Mining Technology 7. in the Unites States, paper presented at Second Research and Applied Technology Symposium on Mined-Land Reclamation, Louisville, Ky., pp. 204-216 (Oct. 1974).

Important data on performance efficiencies are presented for several types and sizes of earthmoving equipment that can facilitate equipment selection in meeting the demands of modern strip mining and reclamation regulations. The industry is turning away from the larger machines because real capacities are much lower than their rated capacities due to increased downtime. In addition, greater flexibility is needed in spoil handling and manipulation. Improvements in the training of surface mining personnel are also suggested. 
164! Ratchye, J.F., Opening a Large Surface Coal Mine (Decker, Montana), Mining Congress J., 59:60-62 (Aug. 1973).

165. Reclamation and Big Dozers at Hanna Coal, Coal Age, 76:80-83, 88 $\because$ (May 1971).

Xi66. Rumfelt, H., cirrent Trends in Strip Mining, Mining Congress.J., of 56:49-52 (Feb. 1970).

167. Saperstein, L.W. and E.S. Secor, Improved Reclamation Potential with the Block Method of Contour Stripping, paper presented at Research and Applied Technology Symposium on Mined-Land Reclamation, Pittsburgh, pp. 1-14 (March 7-8, 1973).

The authors expound a method of simultaneous overburden removal 'and backfllling applicable to contour stripping operations in the Appalachian Region. Called the "block-cut method," the procedure . requires an initial box cut at the middle of the lease area, with alternate overburden and coal removal on each side of the initial cut. Backfilling then proceeds on the mined-out area, whole stripping continues on adjacent cuts, to the end of the lease area. Procedures are outlined for spoil segregation and placement, with acidic material remaining along the highwall buried under two or more leach zones. Topsoil is stockpiled on the outslope and returned to the graded backfill area, returning it to original contours as required by Pennsylvania 1aw. Tables of cost comparisons are included, comparing operational costs of the "block-cut method" with those of more conventional operations. The article is technical but significant in terms of reclamation planning in areas of steep slopes.

168. Selner, J.E., Reclamation Research in the Rocky Mountain Foothilzs, Third Symposium on Surface Mining and Reclamation, Louisville, Ky., I: 16-20 (Oct. 21-23, 1975).

This article discusses reclamation in the province of Alberta, Canada. Problems of reclamation relating to climate, relief, soils, geologic materials, and existing and available vegetation are analyzed. A brief look at the Alberta Forest Service and its involvement in reclamation is examined.

This article is intended for those persons fomiliar with vegetative species for land reclamation.

169. Soler, Darwin, New Methods and Techniques in Kaolin Mining, Chapter 15, Case Studies of Surface Mining, Howard L. Hartman, (ed.), American Institute of Mining, Metallurgical and Petroleum Engineers, Inc., New York, pp. 224-238 (1969).

170. Stefanko, R., R.V. Ramani, and M.R. Ferko, An Analysis of Strip Mining Methods and Equipment Selection, Research and Development Report No. 61, hoffice of Coal Research, U.S. Department of the Interior, Washington, D.C., 134 pages (1973). 
This study is an assessment of surface mining methods and equipment. Methods are examined by region in terms of productivity and costeffectiveness. The assessment of equipment is on the same basis but includes discussion of availability and reliability. The report is intended for government officials, the general public, and mine operators. As such, it is relatively nontechnical. .However, technical data and specifications are presented. It is essential background material for evaluating the capabilities of modern surface mining and reclamation equipment.

171. Strachura, J.A., Sr., Solving Safety Problems ReZated to Surface Coal Mining, Mining Congress J., pp. 75-79 (June 1976).

This article discusses the safety program used by AMAX Coal Company. X Organization structure is depicted and safety policy is lightly examined. AMAX Coal Company uses a system of management by objectives in their safety programs; they also stress the importance of involvement of operators, supervisors, and safety inspectors. The article is non technical and is relevant in its suggestions for promoting safer operating procedures and conditions.

172. Stripping and Reclamation at Robert Bailey Coal Company, Coal Age, 71:66-70 (Sept. 1966).

X 173. Study of Strip and Surface Mining in Appalachia, U.S. Department of the Interior, U.S. Government Printing Office, Washington, D.C. (1967).-

This study was prompted by a public làw directed at developing Appalachia. The report reviews all methods of surface mining as they are used in the Appalachian region for coal, sand and gravel, stone, and clay. It also provides production figures and tables for the various states and commodities. Reclamation cost figures are given for each area and for five types of contour mine reclamation. Although the cost figures are out of date, the report gives perspective to Appalachia's standing in comparison to other mineral producing states. The goal of the study is to prevent future devastation of the environment while promoting economic growth of the minerals industry. The prohibition of mining is recommended if reclamation at certain sites is not feasible.

X.174. Surface Mining. . . A Changing Industry, West Virginia Surface Mining and Reclamation Association, Charleston (1975).

Types of surface mining and reclamation operations now pracțiced in West Virginfa are described. After-mining land use and environmental protection are emphasized. Methods of reclamation for various end uses of the land are discussed. The publication is informational with the general reader clearly in mind. Graphics and photography that are included to illustrate the methods discussed are well designed.

175. Surface Mining of Coal, Special Report No. 6, Investor Responsibility Research Center, Inc., Washington, D.C. (Oct. 1973).

It is expected that coal w111 bear the greatest burden in meeting future energy demands. Federal legislation is pending that will entail 
more extensive regulations. Area mining in the Central Great Pla1ns comprises two-thirds of all strip mining, where reclamation of most disturbed land is relatively inexpensive due to the generally lower relief of the terrain. The reclamation of contour mined areas in the Appalachian coal fields is more difficult. The authors attempt to forecast future legislation and its effects on the coal mining industry. The report is general and nontechnical in nature and it addresses public officials and private interests that may be considering investments in surface coal mining companies.

176. Surface Mining of Coal, Mining Congress J. (Feb. 1974).

This report describes the general outlook of surface coal mining in the U.S. Bituminous coal production in the U.S. In 1973 was, for the second year in a row, highlighted by surface mines producing more coal than underground mines, with total output for the year estimated at 590 million tons.

Emphasis is placed on coal reserves in the first section of this article with the remaining sections dealing with such topics as equipment and land reclamation.

This report assumes some knowledge of mining equipment and its operation.

X177. Su, Y.L., C.B. Manula, and T.V. Faikie, Design and PZanning Open Pit Mining Operations with Computer Simulation Solutions, Department of Mining, Pennsylvania State University, University Park, and Bureau of Mines, USDI, cooperating (Grant No. G-0190439-Min. 22) (n.d.).

178: Thurmond, R.E., A Review of AZZuvial Overburden Stripping Methods, I Mining Congress J. (Oct. 1962).

179. Waldbieser, W.C., DeveZopment of Equipment for Cast Overburden

K Reclamation, Mining Congress J., pp. 50-5I (July 1968).

180.

, Recent Developments in Open "Cut Mining and Machines, Mining Engineering, pp. 43-45 (Oct. 1974).

A description of three surface mining sites and their operations is presented in this paper. AMAX Coal Company's Ayrshire, Leahy, and Bell Ayr Mines are the case examples used to show how mining efficiency can be increased with "new-old" or "old-new" equipment and techniques.

A knowledge of mining equipment will aid the reader in better understanding the gist of the article.

181. Walker, D.E., Captain Mine - A Total Team Effort, Case Studies of Surface Mining, 2nd International Surface Mining Conference, Minneapolis, American Institute of Mining, Metallurgical and Petroleum Engineers, New York, pp. 47-56 (1969). 
182. Zachar, F.R., Factors Influencing the. Selection of Mining Systems, Uining Congress J., p. 32 (Oct. 1969).

183. Zube, E., A New Technology for Taconite Badlands; New Mining Techniques (Offer a Change to do more than Create a 'Moonscape' in Wisconsin, (Landscape Architecture, 56(2):135-140 (Jan. 1966). 
THIS PAGE

WAS INTENTIONALLY

LEFT BLANK 


\section{RECLAMATION METHODS AND TECHNOLOGY}

\subsection{GENERAL WORKS}

184. Barnhise1, R.I., J.L. Poweil, and G.W. Akin, Keys to Successful Neclamation in Western Kentucky, Third Symposium on Surface Mining and Reclamation, Louisville, II:140-151 (Oct. 21-23, 1975).

185. Blakely, J.W., Perry Brothers Perform Superb Reclamation, Coal Mining and Processing, 12:36-39 (March 1975).

186.

, New Triple-Head Auger Proves Its Worth in

Low Seam Coal, Coal Mining and Processing (Oct. 1975).

$\checkmark$ This article discusses the operation and value of a new triple head auger, being used in Perry County, Kentucky, and owned by Pine Branch Coal Sales, Inc. Methods of reclamation and equipment in use at the mining site are also discussed. The article assumes a working knowledge of surface mining and reclamation.

$X_{187}$ (ed.), Horne Bros. Mine -- Best of Three Worlds, Coal Mining and Processing, Vol. 12 (Feb. 1975).

This short article describes a haulback operation in Virginia. Equipment used in the mining procedure is listed and reclamation efforts are examined briefly. The paper is not technioal; however, a knowledge of mining terminology would be helpful for complete comprehension.

188. Carter, R.P., R.E. Zimmerman, and A.S. Kennedy, Strip Mine Reclomation $\checkmark$ in IZZinois, Energy and Environmental Systems Division, Argonne National Laboratory, prepared for Illinois Institute for Environmental Quality, 295 pages, tables, illustrations (Dec. 1973).

This is a report of a project to develop cost-effective alternative plans for the reclamation of lands strip-mined before Illinois reclamation laws went into effect. The objectives of the project were to design and develop a demonstration project that would establish and verify inputs such as reclamation and technological feasibility; to establish and develop a base of practical experience with alternative methods of reclaiming the land; and to develop and apply data-collection and management systems that would allow the large quantities of information required to be assembled and analyzed efficiently. Extensive discussion of environmental problems and the reclamation technology available to combat them are presented in terms of cost-effectiveness. Vartous 1 and use appendices include a socioeconomic portrait of Illinois and a summary of the tax structure of pre-law lands. Appendix B is an in-depth examination of the state of the art of reclamation technology. Four proposals are made for demonstration projects that deal with both acidic and neutral spoil areas. The report is technical but provides background data necessary for reclamation planning in I1linois. 
X 189. Coal Strip-Mined Land in Indiana, Special Report No. 6, State of Indiana, Department of Natural Resources, Geological Survey, Bloomington, Ind. (1972).

Almost 100,000 acres of 1 and have been disturbed by strip mining in southwestern Indiana in the past 50 years. Pike, Warrick, and Clay Counties contain about two-thirds of the total Strip mined land in these counties amounts to about $4 \%$ of the total land area of Indiana and $2 \%$ of the total land area of the 21 counties in southwestern. Indiana that contain coal reserves. Coal has been removed from about 75,000 acres, with spoil dumped on unmined land accounting for $27 \%$ of the total disturbed area. The Springfield (V) coal member accounts for $50 \%$ of the coal produced in Indiana, of which $80 \%$ has been mined in Pike and Warrick Counties. Strip mining takes essentially all coal from the area mined, while deep mining leaves about $50 \%$ of the coal in the mined area as roof support. The report is statistical in nature and assumes some prior knowledge of surface mining and land use.

X190. Checking the Impact of Mining, Reprints from Soll Conservation Magazine, Soil Conservation Service, U.S. Department of Agriculture, Washington, D.C., 14 pages (various dating).

The reprints are a collection of articles on various aspects of surface mine reclamation by Soil Conservation Service authors. The articles approach such subjects as cooperative industry-governmental efforts, refuse pile removal, mine reclamation, Florida phosphate mine reclamation, and erosion and sediment control. They are primarily thumbrail sketches to provide an overview of current reclamation research progress and problems, and are intended for the general public.

191. Dick, J.H., and J.V. Thirgood, Development of Land Reclamation in British Columbia, Practices and Problems of Land Reclamation in Western North America, Mohan K. Wali (ed.), University of North Dakota Press, Grand Forks (1975).

British Columbla possesses great diversity in geology, climate, soils, and vegetation, resulting in wide variations in site conditions for mined land reclamation. The Coal Mines Reclamation Act (1969) placed the onus of developing reclamation technology and procedures on industry. Reclamation has been shown to be biologically possible throughout the province. In general the shortcomings of reclamation procedures are due to failure of the governmental departments involved to set up standards. Continued development of reclamation technology in British Columbia will require more cooperation between government and industry.

192. Donner, D.L., and E. Kruse, Bureau Seeks New Surface Mining and Reclamation Techniques, Coal Age, 80(8):127-128 (July .1975).

The U.S. Bureau of Mines suggests an increase in surface mine productivity, but with improved reclamation techniques. Thus, the Bureau initiated a research and development program to improve reclamation technology, with. a major goal being the integration of mining 
and reclamation activities into a cost-effective mining system. Studies are under way which will examine mine systems throughout the U.S. The article is a brief overview of ongoing research and points out topics for future research.

193. Grim, E.C., and Ronald D. Hill, Environmental Protection in Surface Mining of Coal, Office of Research and Development, U.S. Environmental Protection Agency, Cincinnati, Ohio, 276 pages, (Oct. 1974).

Sor

This report emphasizes the premining planning and integration of surface mining and reclamation operations for increased efficiency and effectiveness. Strip and auger mining methods and equipment are described and their advantages or disadvantages are evaluated in terms of operating efficiency and their potential for simultaneous mining and reclamation procedures. Recommendations are made that new techniques be used to maximize the aesthetic potential of reclaimed spoil banks and to reduce the dangers of erosion, landslide, and water pollution. Reclamation methods discussed include spoil segregation and placement, topsoiling, grading, burying of toxic spoil materials, and revegetation. Blasting techniques designed to reduce vibrational damage to structures are outlined. Haul road design and maintenance for erosion control and sediment reduction is considered in detail. A detailed discussion is also presented on methods for the control of spoil bank erosion by spoil manipulation techniques, diversion ditches, and check dams.

! Revegetation and acid mine drainage problems are outlined; and methods and techniques for effective cover establishment and spoil stabilization are recommended. One chapter is devoted to an overview of reclamation costs, including backfilling, grading, and revegetation. Appendices present guidelines for planning, location, construction, maintenance, and abandonment of coal-haul roads and drainage structures. References are listed at the end of each section, and future research needs are highlighted in a separate section. The report is well written, with the plonning profession kept firmly in mind in terms of overall approach and recommended policies, activities, and design criteria.

194. Grube, W.E., Jr., R.M. Smith, R.N. Singh, and A.A. Sobek, Characterization of Coal Overburden Materials and Mine Spoils in Advance of Surface Mining, Research and Applied Technology Symposium on MinedLand Reclamation, Pittsburgh, Penn., pp. 134-152 (March 7-8, 1973).

Research was carried out to determine the chemical and mechanical properties of coal overburden materials in order to characterize them before beginning detailed planning. It was felt that base information of this nature was essential to proper preoperations planning of mining and reclamation. Potential spoil characteristics may limit the choice of future land use or determine the operational method of mining and restoration for reclamation. Acid or base content was determined, as was the presence or absence of minerals and trace elements essential for the establishment of plant cover. Field tests, such as the determination of carbonate content by dropwise addition of acid, and relative pyrite content by noting the color of a rock, were made semiquantitative by comparison with laboratory data. Laboratory experiments were performed with direct oxidation of overburden samples, using a 
titration technique and the LECO for determination of sulfur content to measure the acid-producing potential of overburden materials. The evaluative procedures used are clearly set out in accompanying appendices.

195. Hadley, R.F., Base-Line Data for Evaluating Rehabilitation Potential of Western Coal Lands, Third Symposium on Surface Mining and Reclamation, Vo1. II, Louisville, Ky., pp. 1-2 (Oct. 21-23, 1975).

196. Hamilton, L.W., Jr., Reclamation of Steep Slope Surface Mining, paper presented before the American Mining Congress, 1974 Coal Convention, Pittsburgh, Penn., May 8, 1974; Green Lands, West Virginia Surface Mining and Reclamation Association, Charleston, pp. 8-10 (Fa11 1974).

The author discusses drainage and erosion control'structures, sediment ponds, head-of-hollow fill and integrated mining and reclamation procedures in terms of premining planning. The emphasis is on achieving maximum productivity and minimum operating costs. Haul-back methods and problems that ensue are discussed in the case of stripping, augering, and reclaiming where two or more splits extst.

The article is well written and easily understood. It is a good presentation of the need for careful premining planning and the early placement of drainage facilities, including water treatment plants.

197. Hines, B.J., H.W. Everett, and C.A. Foster, Meeting the ChalZenge of Reclamation, paper presented before Second Research and Applied Technology Symposium on Mined-Land Reclamation, Louisville, Ky., pp. 101105 (Oct. 1974).

198. Hrovatic, Car1, and S.T. Sorrel1, Environment - Land, Elements of Y Practical Coal Mining, Samuel M. Cassidy (ed.), American Institute of Mining, Metallurgical, and Petroleum Engineers, New York, pp. 510-522 (1973).

199. Hutnik, R.J., and Grant Davis, Ecology and Reclamation of Devastated Land, Gordon and Breach, New York, 2 Vols., 1042 pages (1973).

The proceedings of a NATO Advanced Study Institute held at Pennsylvania State University, on the Ecology and Revegetation of Drastically Disturbed Areas, have been published in a single compilation of two volumes for ready reference. Papers are concerned with a wide range of topics including spoil chemistry, pollution control, spoil neutralization, revegetation, spoil grading, and reclamation planning. The level of technical background required for understanding the papers varies from none to considerable.

200. Jones, W.G., Reciamation Today in Pennsylvania, Coal Mining and Processing, Chicago, 11:33-35 (June 1974).

201. Medvick, Charles, The Indiana Coal Industry Surface Mining Reclamation

Program, Proc. the Indiana Academy of Science for 1970, 80:346-350

(1971). 
There have been 101,178 acres disturbed in Indiana in the process of surface mining for coal as of June 1970. Over 3,000 acres are currently being disturbed annually. The Indiana coal mining industry operates the oldest continuous surface mining revegetation program in the country. Beginning in 1920,16 conifer and 28 broadleaf tree species and other perennials have been planted. The future trend of vegetation type is shown to be an increase in forage production and a decrease of forest plantation. Some surface-mined lands have been successfully reclaimed for tillable crop production. Implications of the current (1967) reclamation law remain unresolved.

The article provides technical information of value in the consideration of tree species for reforestation programs on reclaimed spoils. Also, data are provided regarding soil treatment and plantings for agricultural development of reclaimed land. Largely technical, the article requires a knowledge of agronomy as it relates to revegetation to be of value in reclamation planning.

202. Millford, R.H., E.P. Farrand, and R.W. Ruble, Strip Mine Spoil ReclaJmation, Agricultural and Home Economics Extension Service, Pennsylvania State University, University Park, 15 pages (n.d.).

Designed as a guide to planning for strip mine reclamation and after-mining land use, this publication provides a good examination of grading, backfilling, and planting requirements for various future land uses. Extensive discussions consider management practices and policies after reclamation is completed. Major emphasis is placed on careful planning before the commencement of surface mining. The report is aimed at readers with a nontechnical background who may be contemplating surface mining on their own land.

203. Moore, R.T., D.A. Koehler, and C.L. Kling, Surface Mine RehabiZitation in Northwestem Colorado, Third Symposium on Surface Mining and Reclamation, Louisville, Ky., II:171-184 (Oct. 21-23, 1975).

The purpose of this paper is to examine the reclamation potential of surface mined lands in northwestern Colorado, evaluate some of the reclamation procedures being practiced there, such as analyzing and rehabilitating vegetation, and suggest means of improving these practices to achieve a more productive or useful landscape.

This paper assumes a knowledge of vegetative species for full comprehension of its contents.

204. Moudgil, B.M., and J.P. Bunch, Mined Land Reclamation by the Florida Phosphate Industry, Preprint No. 75-A0-325, Fall Meeting, Soclety of Mechanical Engineers of the AIME, Salt Lake City, Utah, 19 pages (Sept. 1975).

This paper examines the Florida Phosphate mining industry with emphasis on reclamation techniques. After showing where the phosphate mining industry is located, and a brief description of the mining operation, the authors describe waste products associated with the mining operation, particularly the nature and composition of slimes. Methods of slime consolidation are also presented. 
Major impacts of the phosphate mining operation are described. The authors also discuss different reclamation techniques for mined areas such as: recontouring spoil, dredging, anu overburden covering of tallings. Each technique has certain advantages. The reclamation of settling basins, which differs from reclamation of mined areas, is also examined.

This work is not highly technical, but for complete comprehension it does require a knowledge of phosphate mining terms and operations.

205. Newport, Bobby, and J.E. Moher, State of the Art: Sand and Gravel Industry, EPA-660/2-74-066, National Environmental Research Center, U.S: Environmental Protection Agency, Corvallis, Ore., 40 pages (June 1974).

This report presents an overview of the sand and gravel industry in the United States and its relationship to the environment. The fate and effects of sediment generated by this surface mining activity on the benthic, planktonic, and $f i s h$ communities of our waterways are discussed in detail. Problems of the sand and gravel industry, types of operations, status of current treatment technology, and legislation affecting the industry are reviewed. The report assumes a minimum level of technical background for comprehension.

206. Pudley, T., and J. Becker, Mined Land Reclamation on the Northern Great X Plains - Indian Head Mine, Mining Congress J., 61:18-23 (Apri1 197.5).

207. Restoring Surface Mined Land, Misc. Publication No. 1082, U.S. Department of Agriculture, Washington, D.C., 14 pages (Rev. June 1973).

The publication is a brief, but informative discussion of the need for reclamation, the environmental concerns that arise in surface mined areas, and the Department of Agriculture's record of accomplishment in reclamation research. Principles for a national surface mined land conservation effort are outlined.

208. Robertson, D.R., Surface Mined Land Reclomation in Southeast Kansas, Third Symposium on Surface Mining and Reclamation, Louisville, ky.,
II:229-239 (0ct. 21-23, 1975). kansas. It states what techniques and expertise are available, with critical needs being the continuity of a coordinated. motivated work force and financial incentives to get the job done.

The report is addressed to the general public.

209. Sandoval, F.M., J.J. Bond, J.F. Power, and W.0. Willis, Lignite Mine Spoils in the Northern Great Plains - Characteristics and Potential for Reclomation, paper presented before the Research and Applied Technology Symposium on Mined-Land Reclamation, Pittsburgh, Penn., pp. 117-133 (March 7-8, 1973). 
Overburden materials left as spoils on the surface after strip mining for lignite and subbituminous coal in North Dakota, Montana, and Wyoming were studied in the field laboratory and to evaluate their potential as soil materials. Many materials left as spoil provide a very good environment for vegetative growth. Materials from the Tongue River and Sentinel Butte Formations within the Fort Union group were often extremely fine-textured (Montmorillonitic), moderately saline, and highly impermeable, and easily erodible by water. Available phosphorus in spoil materials was very low. Available nitrogen varied considerably, depending on the age of the exposed spoils. Treatments showing promise for reclamation include fertilization (especially phosphate) in combination with the use of topsoil and vegetative mulches as amendments for calcium. Response to gypsum in field studies has been disappointingly slow. Strip mining is accelerating greatly in the Northern Plains; therefore, means must be developed to reduce the textural, sodic, and fertility limitations of soils before appreciable growth and survival of desirable perennial plants can be obtained under the semiarid climate of the region. The paper assumes prior knowledge of reclamation techniques and problems.

210. Sawyer, L.E., and J.M. Crowl, Land Reclamation, Surface Mining, Eugene P. Pfieder (ed.), Seeley W. Mudd Series, American Institue of Mining, Metallurgica1, and Petroleum Engineers, New York, pp. 141-145 (1968).

This article analyzes land reclamation in regard to soil conditions, agricultural restoration and reforestation. State laws regarding land reclamation along with foreign reclamation in progress are also discussed. The author briefly describes the outlook for land reclamation in the United States.

A knowledge of soil characteristics is. lielpful in the comprehension of sections of this article.

211. Shields, D.H., Innovations in Tailings Disposal, paper presented before First Symposium on Mine and Preparation Plan Refuse Disposa1, Louisville, Ky., pp. 86-90 (1974).

$X 212$.

The Florida Phosphate Slimes Problem: A Review and a Bibliography, Staff, Bureau of Mines Tuscaloosa Metallurgy Research Laboratory, Tuscaloosa, Alabama; Information Circ. 8668, Bureau of Mines, U.S. Department of the Interior, Washington, D.C., 41 pages (1975).

The Florida phosphate industry, which supplies about threequarters of domestic phosphate fertilizer, produces tremendous volumes of phosphatic clay wastes (slimes). The slimes retain a high percentage of water for extended periods of time. Slimes also pose anienvironmental hazard because normal disposal techniques involve storage on the ground surface behind earthen dams.

Although extensive research has been undertaken by numerous organizations to dewater slimes, no completely satisfactory solution has been developed. In June, 1972, a cooperative effort by the U.S. Bureau of Mines and the Florida phosphate mining industry was initiated to develop a solution for dewatering the phosphate slimes. This report 
discusses various aspects of the slimes problem, reviews past research, makes recommendations for future research, and provides a bibliography of references and patents dealing with the subject.

213 OTobler, R.H., Problems Associated with Mine Development on Federal Coal, Third Symposium on Surface Mining and Reclamation, Loutsville, Ky., I: 8-11 (Oct. 21-23, 1975). Iuff 214. Wahlquist, B.T., Developing Surface Mine Reclamation PZans, Mining
Congress J., 62:35-38 (Jan. 1976).

X 215. Waldbeiser, W.C., Development of Equipment for Cast Overburden Reclamation, Mining Engineering, pp. 43-45 (Oct. 1974).

Each year there is more emphasis on grading cast overburden, which is creating an economic unbalance that must be absorbed in the cost of coal. An economical tool for reclamation is needed to offset the ever-increasing, economic unbalance. This report endeavors to relate the goal and feasibility of such a reclamation tool.

Reclamation laws adopted over the past few years indicate that new equipment is needed. To date (1974) reclamation equipment has been overlooked or sloughed off while the emphasis has been on prime stripping tools, which seemed to be the Industry's most urgent need.

Prime stripping equipment has been designed to perform its functions at reasonable cost. However, land reclamation equipment lags far behind. This article discusses reclamation equipment and technological needs in regard to reclaiming strip mined lands.

This article is intended for the surface mine operator und assumes prior knowledge of mining and reclamation equipment.

$\chi$ 216. Wobber, F.J., and Donald Garofolo, Remote Sensing for Mined Area Reclamation, Applications Inventory, Bureau of Mines, U.S. Department of the Interior, Washington, D.C., 40 pages (1971).

The purpose of this study is to document applications of aerial remote sensing to coal mined area reclamation, and to collect information concerning available data banks.

This study is a preliminary step in detailing mined land reclamation objectives and documenting reclamation -- related remote sensing applications known to date.

The objectives of the study were:

1. To prepare, a summary of mined area information requirements to which remote sensing methods might contribute

2. To document remote sensing techniques as applied to mined area reclamation, 1.e., problem-oriented, state-of-the-art summary. 
3. To inventory remote sensing data banks having imagery potentially useful for studies of coal-mined land reclamation.

This study is intended for those persons involved in mine surveying and/or land-use planning.

\subsection{SPOIL HANDLING AND MANIPULATION}

X217, Griffith, F.E., M.0. Magnuson, and R.L. Kimball, Demonstration and Evaluation of Five Methods of Secondary Backfiliing of Strip-Mined Areas, Report of Investigations 6772, Bureau of Mines, U.S. Department of the Interior, Washington, D.C., 17 pages, tables, and illustrations (1966).

Cost data are given for five methods of secondary backfilling of strip mines that previously had been partially backfilled. The operations were conducted in north-central Pennsylvania; an average of 600 linear feet of highwall were backfilled in each trial. The major advantages and dieadvantages of each method are discussed.

X 218. Grube, W.E., Jr., and R.M. Smith, Field Clues Useful for Characterization of Coal Overburden, Green Lands, pp. 22-24 (Winter 1974).

This article presents simplified color tests for field identification of overburden materials. The tests are indications requiring laboratory confirmation, but have proved useful in recognizing important rock and soil properties in the field.

X219.

Howland, J.W., New Tools and Techniques for Reclaiming Lands, Research and Applied Technology Symposium on Mined-Land Reclamation, Pittsburgh, Penn., pp. 42-67 (March 7-8, 1973).

This report is concerned with the development of a large angleblade for spoil handling purposes in land reclamation. The author presents a brief overview of the economics of spoil-handling and equipment requirements in terms of cost and horsepower constraints. A pushtow technique utilizing a 40-ft-wide angle-blade mounted on a Cat D9G tractor is described in detail. Towing is done by a 2 in. steel cable connected to a second tractor that, in effect, provides additional horsepower to move a greater load of spoil material at a single pass. Although an experimental test program has shown that dirt-handling capacity exceeds potential capacity by $30 \%$, the program was discontinued. The lift capacity of the hydraulic cylinders was found to be marginal for the weight of the blade under operating conditions. It was thought that a rearrangement of counter-balance weights may provide a solution. Appendices include a guideline for the evaluation of bulldozer performance and a table of volume and work requirements in horsepower hours associated with the leveling of geometrically uniform spoil banks. The article deals with a technical engineering problem that, if solutions can be found, bodes well for the development of specialized reclamation equipment. 
220. Jones, J.N., W.H. Armiger, and O.L. Bennett, Forage Grasses Aid the Transition for Spoil to Soil, Third Symposium on Surface Mining and Reclamation, Louisville, Ky., II:185-194 (Oct. 21-23, 1975).

$X$ 221. May, R.F., Prediating Outslopes of Spoil Banks; Research Note CS-15, United States Forest Service, Northeastern Forest Experiment Station, Berea, Ky., 4 pages (Nov. 1964).

X 222. Riley, C.V., Furrow Grading - Key to Successful Reclamation, Research and Applied Technology Symposium on Mined-Land Reclamation, Pittsburgh, Penn., pp. 159-177 (March 7-8, 1973).

Research results show the beneficial effects of furrow grading over conventional grading that restores land to its premining rather than returning the land to its original erosion surface. Furrow graded spoils were found to be more suited to revegetation due to increased water retention and the resulting leaching-out of toxic substances from the root zone. Very poor results were obtained from a control plot that was returned to original contours. Little vegetation was established and due to runoff material removal was excessive. Other plots were able to establish varying degrees of vegetative cover, depending on plant species that were seeded and planted on each plot. Moisture retention in the soil was found to be enhanced by the tendency of fine material, such as silt and clay, to collect in low areas, with the result that less moisture was lost by evaporation in these sections. It was more difficult to establish vegetation upon the ridges between furrows due to greater moisture loss and the coarser materials found there. During dry periods, the ridges were found to retain little moisture while the valleys between retained moisture quite effectively.

X 223. Timberlake, R.C., Building Land with Phosphate Wastes, Mining Engineering, $21: 30-40$ (Dec. 1969).

Jup

224: Voge1, W.G., Requirements and Use of Fertilizer, Lime, and Mulch for Vegetating Acid Mine Spoils, Third Symposium on Surface Mining and Reclamation, Louisville, Ky., II:152-171 (Oct. 21-23, 1975).

\subsection{ERODION AND SEDIMENT CONTROL}

225. Becker, B.C., and T.R. Mills, Guidelines for Erosion and Sediment Control Planning and Implementation, Maryland Department of Water Resources and Hittman Associates, Inc., Project No. 15030 FMZ (EPA-R272-015), prepared for the Office of Research and Monitoring, U.S. Environmental Protection Agency, Washington, D.C. 228 pages (Aug. 1972).

The principal purpose of the Guidelines is to help those responsible for, or engaged in, urban construction prevent the uncontrolled movement of soil and the subsequent damage it causes. The Guidelines presents a comprehensive approach to the problem of erosion and sediment from beginning to completion of construction. It provides:

1. A description of how a preliminary site evaluation determines what potential sediment and erosion 
control problems exist at a site being considered for development.

2. Guidance for the planning of an effective sediment and erosion control plan.

3. Procedures for the implementation of that plan during operations.

Technical information on 42 sediment and erosion control products, practices, and techniques is contained in the appendices. In addition, a cross-index and a glossary of technical terms used in the document are provided.

226. Brenner, F.J., et al., Evaluation and Recommendations of Strip Mine Reclamation Procedures for Maximum Sediment-Erosion Control and WildZife Potential, Third Symposium on Surface Mining and Reclamation, Louisvil1e, Ky., II:2-23 (Oct. 21-23, 1975).

This study was undertaken to determine the value of reclaimed surface mine lands as a recreational resource providing fish and wildlife habitats. The importance of naturally occurring vegetation, as well as that utilized during reclamation, was analyzed in order to.. gain an understanding of the ecology of these areas. The ultimate objective is to obtain an understanding of surface mine land as an ecological unit that may be utilized by the mine operator prior to, during, and after mining to enhance the recreational resources and aesthetics of the community. This report is intended for mining and. reciamation engineers and planners.

Guf 227. Caspa11, F.C., Soil DeveZopment on Surface Mine Spoils in Westerm IZlinois, Third Symposium on Surface Mining and Reclamation, Louisvilie, Ky., II:221-228 (Oct. 21-23, 1975).

228. Coalgate, J.L., D.J. Akers, and R.W. From, Gob Pile Stabilization, Reclamation, and Utilization, Research and Development Report No. 75, Interim Report No. 1, Contract No. 14-32-0001-1218, Coal Research Bureau, School of Mines, West Virginia University, Morgantown, (Feb. 1972-May 1973).

Although intended for those dealing with problems in the reclamation of gob piles and culm banks resulting from underground coal mining, this publication contains much that is useful in strip mine reclamation. The first part of the report contains information on the extinguishment of refuse pile fires, and evaluates the relative efficiency of each method, including an indication of future possible problems that may result. Slope stability is a major real or potential problem, depending on individual circumstances associated with spoil banks and must be addressed at the planning stages of a reclamation project. Several methods of stabilizing slopes are presented in detail through both mechanical treatment and chemical additives. Revegetation is a large part of the reclamation process for aesthetic and practical reasons. Plants stabilize slopes and provide an oxidation zone that 
helps to control acid drainage from the underlying spoil material. The authors present a detailed discussion of revegetation methods and associated problems. Soil treatments that may be applicable are outlined and discussed. Of particular value, is a table of shrubs, trees, cacti, grasses, forbs, and legumes that have been tested on reclamation sites, with an evaluation of their performance and characteristics. The work is intended primarily for mining or civil engineers, working directly on gob pile stabilization or reclamation.

229. Cook, F.X., Jr., G.K. Gantner, and L.M. McNay, Current and Recommended Overburden Handling and Reclomation Practices at Western Surface Coal Mines, Third Symposium on Surface Mining and Reclamation, Louisville, Ky., 1:215-236 (Oct. 21-23, 1975).

The article examinee current overburden handling and reclamation practices at existing Western surface mines. The advantages and shortcomings of methods and equipment are carefully set forth and recommendations for short- and long-term improvements are suggested. Well written and easily readable, the article contains an excellent over-view of eciuipment in liestern mines, and includes easily uncerstrod. graphics illustrating the principal characterisitcs of each mining and reclamation system presently in use.

$\chi 230$.

Deane, J.A., Reclamation and Water Control of Stripped Coal Mines, Missouri University, Engineering Experiment Station Engineering Series B, pp. 8-15, (April 15, 1962).

$X$ 231. Gould, W.L., S. Miyamoto, and D. Rai, Characterizing Overburden Materials before Surface Mining in the Fruitland Formation of Northwestern New Mexico, Third Symposium on Surface Mining and Reclamation, Louisville, Ky., I:80-94 (Oct. 21-23, 1975).

Many difficult problems involved in reclamation of mine-spoils can be eliminated if properties of overburden materials are fully known in advance of surface mining. This report summarizes studies made on the eastern section of the El Paso Natural Gas Company-Consolidation Coal Company lease area in the coal-bearing Fruitland formation in New Mexico. Studies were made in the following sequence and reported here as such: (1) vegetative survey; (2) soll investigation; and (3) investigation of overburden materials below the surface:

This report assumes knowledge of arid-land soils and vegetative types for the comprehension of its contents.

X 232. McCormack, D., Soil Reconstmuction: Selecting Soil Material for Surface Placement in Surface Mine Reclamation, paper presented at American Mining Congress 1976, Coal Show, Detroit (May 10-13, 1976).

This paper presents methods for reconstructing the soil after mining that will preserve the productive capacicy of the land and also preserve environmental and aesthetic values. The definition of topsoil. is discussed, and a systematic evaluation of the quality of the various strata in the overburden, including the natural surface soil, is outlined. 
This article is not technical, and would be of interest to soil scientists, environmental or land-use planners, mine planners, and the general public.

Qjof 233.

Reed, L.A., Controlzing Sediment from Construction Areas, Third Symposium on Surface Mining and Reclamation, Louisville, Ky., II:48-57 (Oct. 2123, 1975).

X 234. Seith, R.T., O.R. Allen, and J.C. Kirkpatrick, PiZot PZant Evaluation of Soil Losses from Disturbed Land, Third Symposium on Surface Mining and Reclamation, Louisville, Ky., II:24-41 (Oct. 21-23, 1975).

X 235. Van't Woudt, B.D., Erosion Control on Strip Mined Land, Hawaii Farm Science, 10:10-11 (July 1961).

236. Soil Erosion Prevention on Bauxite StripMined Soils in Howaii, Technical Progress Report 123, Agricultural Experiment Station, Hawaii Universtiy, 8 pages (1959).

X 237. Van't Woudt, B.D., and G. Uehara, Erosion Behavior and Control on a Strip Mined Latosolic Soil, Technical Bulletin 46, Agricultural Experiment Station, Hawaii University, 36 pages (Oct. 1961).

\subsection{REVEGETATION}

$X$ 238: Aldon, Earl, F., Techniques for Establishing Native Plants on Coal Mine Spoils in New Mexico, Third Symposium on Surface Mining and Reclamation, Louisville, Ky., I:21-28 (Oct. 21-23, 1975).

$X$ 239. Berg, W., Use of Soiz Laboratory Analyses in Revegetation of Mined Londs, Mining Congress J., 61:32-35 (April 1975).

X 240. Blizzard, S.H., and S.L. Shaffer, The Davis Project: From Black to Blue, Green Lands, pp. 13-16 (Fall 1974).

X 241. Boyce, S.G., and D.J. Neebe, Trees for Planting on Strip-Mined Land in IZZinois, Technical Paper 164, United States Forest Service, Central States Forest Experiment Station, 33 pages (Nov. 1959).

X 242. Breeding, C.H.J., Crown Vetch as an Aid to Strip-Mine Reclamation, Mining. Congress J., 47:70-71 (April 1961).

X243. Brown, J.H., and E.H. Tyron, Establishing of Seeded Black Locust on Spoil Banks, Bulletin 440, Agricultural Experiment Station, West Virginia University, Morgantown, 34 pages (Jan. 1960).

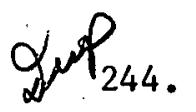

Capp, J.P., and.D.W. Gillmore, Soil-Making Potential of Power-PZant Fly Ash in Mined-Land Reclamation, Research and Applied Technology Symposium on Mined-Land Reclamation, pp. 178-186 (March 7-8, 1973).

Treatment of coal wastes from surface and deep mining with fly ash results in a soil cover which will sustain grasses and legumes. The beneficial effects of using fly ash for this purpose are discussed along with techniques for reclaiming with fly ash. 
Cost estimates for fly ash reclamation of strip soil and refuse banks are attractive and in some cases may be cheaper than alternative methods. The paper is of value in planning for the use of fly ash in a reclamation program, and is clearly understandable for those with nontechnical backgrounds.

245. Capp, J. P., D.W. Gillmore, and D. Simpson, Coal Waste Stabilization by Enhancing Vegetátion, Mining Congress J., 61:44-49 (May 1975).

246. Dale, M.E., Interplant Alder (Alnus glutinosa) to Increase Growth in Strip-Mine Plantations, Research Note CS-14, Northeastern Forest Experiment Station, U.S. Forest Service, Berea, Ky., 4 pages, (Oct. 1963).

247. Denuy1, D., Survival and Growth of Hardwood Plantations on Strip Mine Spoil Banks of Indiana,, J. of Forestry, 60:603-606 (Sept. 1962).

$X 248$.

Finn, R.F., Ten Years of Strip-Mine Forestation Research in Ohio, Technical Paper 153, United States Forest Service, Central States Forest Experiment Station, Columbus, Ohio, 38 pages (June 1958).

INA 249. Fisser, H.G., and R.E. Ries, Predisturbance Ecological Studies Improve and Define Potential for Surface Mine Reclamation, Third Symposium on Surface Mining and Reclamation, Louisville, Ky., I:128-134 (Oct. 21-23, 1975).

Surface mining activities in the western U.S. promise to become more and more prevalent with the nation's increasing demand for coal based energy. Strip mining, by definition, destroys existing plantsoil-animal biotic communities. It follows that rehabilitation of such disturbed areas can be assured a high probability of success only by development, prior to mining, of adequate information concerning environmental limitations, biotic inventory and assessment of ecological criteria by monitoring procedures. The major objectives of the study were to:

1. Develop descriptive information and define the vegetation types;

2. Develop vegetation type maps for the base area;

3. Describe present and historical uses of the lease area and their impact on rangeland, and

4. Establish study locations to monitor vegetation production.

The material covered in this report is oriented toward coal producers and reclamation engineers. The report assumes a general knowledge of range ecology.

X250. Freeman, P.G., and W.W. Fowkes, CoaZ-Derived Humus: PZant Growth Effects, Report of Investigations 7203, Bureau of Mines, U.S. Department of the Interior, Washington, D.C., 16 pages (Nov. 1968). 
251. Funk, D.T., Hybrid Poplars on Ohio Spoil Banks, Research Note CS-8, Northeastern Forest Experiment Station, U.S. Forest Service, Berea, Ky., 4 pages (June 1963).

X 252. Goodland, N.L., Use of Poplars in the Restoration of Worked Out Gravel Pits, Cement, Lime, and Gravel, 37:374-376 (Dec. 1962).

X 253. Grandt, A.F., and A.L. Lang, Reclaiming IZZinois Stmip Coal Land with Legumes and Grasses, Bulletin 628, Agricultural Experiment Station, Illinois Untverstty, p. 64 (April 1958).

X 254. Hart, G., and W.R. Byrnes, Trees for Stmip-Mined Lands, Station Paper 136, Northeastern Forest Experiment Station, U.S. Forest Service, Berea, Ky., 36 pages (1960).

X255. , Performance of Trees Planted on Coal-Stripped Lands in the Bituminous Region of Pennsylvania, Pennsylvania State Forest School, Pennsylvania State University, University. Park, 2 pages (1959).

X 256. Limstrom, G.A., Forestation of Strip-Mined Land in the Central States, Agricultural Handbook 166, U.S. Department of Agriculture, Washington, D.C., 74 pages (Feb. 1960).

X 257. Lorio, P.L., and G.E. Gatherum, Relationship of Tree Survival and Yield to Coalspoil Characteristics, Agricultural and Home Economics Research Bulletin 535, Experiment Station, Iowa State University of Science and Technology, Ames, pp. 394-403 (Aprt1 1965).

$\chi_{258 .}$

Lowry, G.L., Alder for Reforesting Coal Spoils in Ohio, J. of Forestry, 60:196-199 (March 1962).

$\chi 259$. - Conifer Establishment on Coal Spoils as Influenced by Certain Site Factors and Organic Addition at Planting Time, Soil Science of America Proc., 24:316-318 (July-Aug. 1960).

X 260. Conifer Growth is Best on Acid Spoizs, Ohio Farm and Home Research, 45:44 (May-June 1960).

X 261. MacLouchlan, R.S., The Role of the Soil Conservation Service's Plant Materials Centers in Reclaiming Surface-Mined Lands, Third Symposium on Surface Mining and Reclamation, Louisville, Ky., II:131-139 (Oct. 21-23, 1975).

X 262. Medvick, c., Why Reforest Surface Mined Areas?, Mining Congress J., 51:86-89 (June 1965).

Х263. Nielson, R.F., and H.в. Peterson, Treatment of Mine Tailings to Promote Vegetative Stabilization, Bulletin 485, Agricultural Experiment Station, Utah State University, Logan, tables and illustrations (June 1972).

The report details research on mine tailing sites in Utah to establish vegetation for erosion control and possible future range use. 
The primary purpose of the program was to revegetate for the control of aeolian erosion in tailings ponds and banks. Tailings samples were studied to determine the chemical composition with the major effort expended at the Kennecott Copper operation at Magna, Utah. A sample was tested in laboratory and greenhouse studies to determine the feasibility of growing various plant species on the tailings and to determine their response to varying conditions of acidity and salinity. The authors present a list of species that were evaluated for revegetation purposes. Studies were also carried on relating to the use of soil amendments for fertilization and acid neutralization, and to the effect of aeolian erosion on revegetation efforts. The report is primarily technical but of value for reclamation planning in similar situations of tailings characteristics, principally in the west.

264. Plass, W.T., Revegetating Surface-Mined Land, Mining Congress J., pp. 53-59 (Apr11 1974).

This article is a review of the most important advances in spoil revegetation. Problems and needs for site evaluation are discussed, as are spoil preparation, fertilization, and seeding. The article provides in ovemivew of current revegetation teciniques.

$\chi_{265 .}$ , Revegetation Projects Dominate Surface Mine Research, Coal Mining and Processing, II:40-42 (Aug. 19.74)

$\mathcal{X}$ 266. Power, J.F., W.O. Willis, F.M. Sandoval, and J.J. Bond, Can Productivity of Mined Land be Restored in North Dakota?, Reprint No. 831, Farm Research, North Dakota Agricultural Experiment Station, Fargo, 31(6): 30-32 (July-Aug. 1974).

Western North Dakota contains about $20 \%$ of the coal reserves of the U.S. With increased use of energy and decreasing. supply of petroleum reserves, North Dakota coalfields will probably be developed and intensively mined before the end of this century. The Northern Great Plains Resource Program estimates that up to 300 million tans of coal may be mined and consumed in western North Dakota annually, a volume equal to $50 \%$ of the coal consumed in the entire United States in 1973. This paper discusses the problems of revegetation on the sodic spoils characteristic of North Dakota coalfields. The emphas is is on restoration of productivity rather than return to natural conditions. Pre-operations planning is called for in mining and reclamation. The paper is technical but easily readable and informative.

267. Riley, Charles V., Ecology -- Ally of Mined Land Restoration, Second Research and Applied Technology Symposium on Mined-Land Reclamation, Louisville, Ky., pp. 54-68, tables and illustrations (Oct. 1974).

The author adheres to a strict definition of ecology, one in which man encourages natural processes to take over mined land sites rather than undertaking extensive reclamation efforts. The scenario of rising national energy needs with increased surface mining of coal as an interim solution is detailed with a brief look at trends in coal and energy prices. Claiming that complete reclamation is unjustified 
from an ecological point of view due to prohibitive costs, the author feels that future land use capability should determine reclamation procedures and the extent of their applieation. Chemical and biological data supporting the natural maturation of mined sites is provided. Another ingredient for success is a long time frame, about one generation. The paper is informative and clear.

268. Seidel, K.W., and K.A. Brinkman, Mixed or Pure Walnut Plantings on Strip-Mined Land in Kansas, Technical Paper, United States Forest Service, Central States Forest Experiment Station, Columbus, Ohio, 10 pages (Feb. 1962).

Х269. Struthers, P.H., Forage Seedlings Help Reclaim Acres of Spoil Banks, Ohio Home and Farm Research, 45:12-13 (Jan.-Feb. 1960).

270. Success of Tree Planting on Strip-Mined Areas in West Virginia, Bulletin 473, Agricultural Experiment Station, West Virginia Universtiy, Morgantown, 35 pages (April 1962).

271. Sutton, Paul, Establishment of:Vegetation on Toxic Coal Mine Spoils, Research and Applied Technology Symposium on Mined-Land Reclamation, Pittsburgh, Penn., pp. 153-158 (March 7-8, 1973).

This is a report of experimental research on the burial of acid material with soil or nonacid spoil. A study was also performed on the neutralization of acid spoils with limestone. It was found that the combination of limestone and fertilizer produced the best plant cover. In addition, investigations were carried out using sewage sludge and cattle manure to increase $\mathrm{pH}$ and organic matter on a spoil site in Illinois. Plant species adaptable to reclamation purposes were evaluated. Tables showing the effects of spoil treatment are given in the appendices. The report is technical in nature, but useful for species selection for acid spoils.

$X_{272}$

Tixier, J.S., Vegetative Rehabilitation and Equipment Workshop, Third Symposium on Surface Mining and Reclamation, Louisville,'Ky., I:242-243 (Oct. 21-23, 1975).

273. Wahlquist, B.T., R.L. Dressler, and W. Sowards, Mined Land Revegetation without Supplemental Irrigation in the Arid Southwest, Third Symposium on Surface Mining and Reclamation, Louisville, Ky., I:29-31 (Oct. 2123, 1975).

The article is a report on research carried out at the Navajo Mine in northwestern New Mexico. Plant species, seeding techniques, and supplemental one-time irrigation were investigated. The research is continuing, since some success was obtained through the use of pioneer species and native plant seeds. The use of catch basins was found to provide protection from wind erosion. Irrigation was used after planting, in effect slmulating the highly episodic nature of precipitation events in the area

The author's work points the way toward the development of effective vegetation techniques applicable to the arid southwest. 
However, considerable knowledge of arid-zone agronomy is needed to derive maximum benefit from the paper.

274. Wolcott, B.H., and W.G. Vogel, Success with the Rangeland Drill ir Mine Spoil Revegetation, Third Symposium on Surface Mining and Reclamation, Louisville, Ky., I:209-214 (Oct. 21-23, 1975).

275. Yamamoto, Teruo, Coal Mine Spoil as A Growing Medium: Amax Belle Ayr South Mine, Gizlette, Wyoming, Third Symposium on Surface Mining and Reclamation, Louisville, Ky., I:49-61 (Oct. 21-23, 1975).

\subsection{SPOIL AMENDMENTS AND FERTILIZATION}

X 276. Hortenstine, C.C., and D.F. Rothwel1, Composted Municipal Refuse as a Soil Amenament, University of Florida, Gainesville, Grant No. EP-00250, prepared for Office of Research and Development, U.S. Environmental Protection Agency, Cincinnati, Ohio, 62 pages (1973).

X 277.

Land Application of Wastewater, Proc. Research Symposium, Report No. EPA 903-9-75-017, U.S. Environmental Protection Agency, Region III, Philadelphia, 94 pages (May 1, 1975).

This report is a collection of articles that deal with wastewater application, treatment systems, and general system design. The articles also discuss environmental and public health concerns relating to recycling of municipal wastewater on land. Most of the articles are technical in nature.

278. Peterson, J.R., and J. Gschwind, Amelioration of Coal Mine Spoils with Digested Sewage Sludge, Research and Applied Technology Symposium on Mined-Land Reclamation, Pittsburgh, Penn., (March 7-8, 1973).

Mine spoils have been successfully reclaimed with digested sewage sludge. Test plots on a barren acidic coal mine spoil in. southern Illinois showed that application of 200-250 dry tons/acre (448-560 dry metric tons/ha) would result in a permanent vigorous grass cover and the upgrading of water quality. Improvements in leachate water quality and in the spoil material itself were confirmed by laboratory column studies in which sludge-treated and untreated acidic spoil material was leached daily for 110 days.

Large acreages of calcareous coal mine spoils are currently being improved with sludge in Fulton County, Illinois. Traveling gun sprayers distribute the liquid sludge on fields graded from the spoils. Berm structures direct all field runoff to retention basins so that water quality may be checked before being discharged to lakes and streams. Other environmental safeguards include nutrient barriers of shrubs and grasses along lakes, streams, and monitoring wells. These are sampled periodically to ensure that no pollution of local water resources occurs. The report is of value for those considering similar treatments, and is comprehensible to the interested reader. 


\subsection{WATER POLLUTION CONTROL}

Х279. Ahmad, M., Coal Mining and Its Effect on Water Quality, Extraction of Minerals and Energy: Today's Dilemmas, Raul A. Deju (ed.), Ann Arbor Science Publishers, Inc., Ann Arbor, Mich. (n.d.)

280. Baumann, A.N., Consolidation of Phosphate Slimes - A Method and Bibliogrophy, 16th Annual Conference, Florida Pollution Control Association, Jacksonville, 11 pages (Oct. 13-Nov. 3, 1965).

281. Baker, D.R. Bhappu, Specific Environmental Problems Associated with the Processing of Minerals, Extraction of Minerals and Energy: Today's Dilemmas, Raul A. Deju (ed.), Dayton, Ann Arbor Science Publishers, Inc., Ann Arbor, Mich. (n.d.)

X 282. Casali, J.T., Heat Drying Sludge from Ponds, Mining Congress J., 61:34-37 (Jan. 1975).

283. Connel1, J.P., W.T. Plass, D.N. Contractor, and V.O. Shanholtz, Water Quality Models for a Contour Mined Watershed, Third Symposium. on Surface Mining and Reclamation, Louisville, Ky., I:179-199 (October 21-23, 1975).

284. Cox, J.L., Phosphate Waste, Proc. Symposium on Mineral Waste Utilization, cosponsored by Bureau of Mines and IIT Research Institute, Chicago, pp. 50-58 (1968).

285. Criteria for Developing Polzution Abatement Progroms for Inactive and Abandoned Mine Sites, Office of Water-Hazardous Materials, U.S. Environmental Protection Agency, EPA 440/9-75-008, Washington, D.C. (Aug* 1975).

This publication is issued under section 309 (e) (2) (B) of Public Law 92-500 and stipulates information for pollution abatement programs.at orphaned mine sites. Detailed information, tabulated regional data, and excellent illustrations guide readers in selecting measures applicable to individual mine sites. Due to abandonment of over 2 million acres of. land, the EPA feels that the adverse environmental impacts of these lands justifies public expenditures on reclamation and pollution abatement programs. This document is directed at qualified professionals in the mining and water pollution control fields.

286. Davenport, J.E., G.W. Kieffer, and E.H. Brown, Disposal of Phosphate Tailings, TVA Report 661, Tennessee Valley Authority,. Division of Chemistry Development, Resources Branch, 125 pages (July 1953).

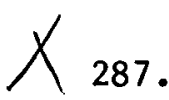
- Disposal of Mining Wastes in the Central Florida Phosphate Field, Proc. 2nd Mineral Waste Utilization Symposium, cosponsored by Bureau of Mines and IIT Research Institute, Chicago, pp. 237-240 (March 18-19, 1970).

DPP 288. Davis, R.W., Acid Zone Hydrology, AZluvial VaZley Floors and the Hydrologic Balance, Third Symposium on Surface Mining and Reclamation, Louisville, Ky., I:40-48 (Oct. 21-23, 1975). 
X289. Havens, Richard, and K.C. Dean, Chemical Stabilization of the Uranium Tailings at Tuba City, Arizona, Report of Investigations 7228, U.S. Bureau of Mines, Department of the Interior', Washington, D.C., 92 pages (Aug. 1969).

290. Hill, R.D., Overview of Use of Carbonate Rocks for ControlZing Acid Mine Drainage, Tenth Forum on the Geology of Industrial Minerals, Proc. Misc. Report No. 1, Division of Geological Survey, Ohio Department of Natural Resources, Columbus (1974).

Acid-mine drainage is the result of oxidation of pyrite and similar nonsulfate material and the release of iron and sulfuric acid into the environment. In addition to the acid water flowing from underground and surface mines, spoil materials in surface mines are acidic and will not support good vegetative growth; thus erosion is a major problem. Lime and Iimestone are the major neutralizing agents used to treat these acidic conditions. Lime is the reagent preferred by industry for treating acid discharges. Although a few companies use natural limestone, agricultural limestone is used to "sweeten" acid spoils. The paper is well written, but technical, and requires a knowledge of acid-mine drainage problems and correctional measures.

291. Kealy, C.D., and R.L. Soderberg, Design of Doms for Milz Tailings, Information Circular 8410, Bureau of Mines, U.S. Department of the Interior, Washington, D.C., 54 pages (1969).

292. Krause, R.R., Mining and Reclamation Techniques to Control Mine Drainage, Fourth Symposium on Coal Mine Drainage Research, Pittsburgh, Penn., Pp. 425-430. (April 26-27, 1972).

Dup 293. Morris, G., Reclaiming Coal from Slurry Ponds, Mining Congress J., 61:38-41 (Dec. 1975).

This publication lists three methods used by Peabody Coal Company to reclaim coal from its slurry ponds. The three basic recovery methods are: (1) "Recover by end loader or dragline and sell without any additional preparation," (2) "Recover by end loader or dragline and blend with raw coal feed to preparation plant," (3) "Recover by Mud Cat and pump to a plant especially designed for slurry." An operational example of each method is described by the author.

DuP 294. Nawrocki, M.A., and R. Vir Kathana, Evaluation of Sedimentation Ponds Used in Surface Coal Mining, Third Symposium on Surface Mining and Reclamation, Louisville, Ky., II:42-47 (Oct. 21-23, 1975).

X 295. Riley, C.V., and J.A. Rinier, Reclamation and Mine Tip Drainage in Europe, Fourth Symposium on Coal Mine Drainage Research, Pittsburgh, Penn., pp. 1-14 (April 26-27, 1972).

The authors of this article discuss reclamation programs, techniques, and management programs presently in use on the tips and related wastes associated primarily with the extraction of coal and lignite in Europe. The article is not technical in nature. 
896. Smith, M., Acid Production in Mine Drainage Systems, Extraction of Minerals and Energy: Today's Dilemmas, Raul A. Deju (ed.), Ann Arbor Science Publishers, Inc., Ann Arbor, Mich. (n.d.)

\subsection{RECLAMATION RESEARCH}

297. Blazer, J.L., D. Crouch, R. Poyser, and W. Sowards, A Venture into Reclamation, Mining Congress J., 61:24-29 (Jan. 1975).

An analysis of soil and its growth characteristics are discussed in this report in reference to reclamation of a New Mexico strip mining area. The author summarizes the present condition of the New Mexico topography with special emphasis on vegetative productivity. Case studies of irrigation are described.

This report is relatively straightforward and is intended for the general reader.

$X_{298 .}$

Barrows, H.L., Agricultural Research Service Research on Strip Mine Reclomation, Research Committee Discussion Forum 28th Annual NACD Meeting, Houston, Texas (Feb. 13, 1974).

An interesting history of the origins of coal and coal mining and the current status of world and U.S. coal reserves is initially presented. Continuing technical advancement of strip mine operations makes feasible overburden-to-coal stripping ratios of $30: 1$ and conditionally includes reserves down to $200 \mathrm{feet}$. Advantages of strip mining over underground mining are clarified with facts and figures on mining and accident rates, and coal lost. Reclamation efforts in the east and west are discussed in suitable detail. Spoil treatments with fly ash, sewage, mulch, and fertilizer, were used and the performance of a wide varieties of grasses and legumes was reported. Chemical differences in reclamation problems between the east and west are explained with clarity and appropriate scientific detail, aimed at increasing the level of understanding of the general public and providing background information for experts in the field of land reclamation.

Camin, L.Q., Mined Land RedeveZopment: South East Kansas Portion of the Ozark Region, University of Kansas, Lawrence (Oct. 1971).

This second annual report describes ongoing research in southeastern Kansas that is concerned with the redevelopment of land disturbed by underground extraction of lead and zinc and by surface mining of coal. Lead and zinc are no longer mined, and utilization of mineral-processing wastes has diminished the amount of land that formerly was committed to waste storage. Strip mining of coal, however, has destroyed the original land surface. The objective of the research is to restore the land to productive uses that generate income and taxes, and improve communities. The publication is in the nature of a progress' report of reclamation activities, and as such is relatively nontechnical. 
X300. Carlson, C.G., and W.M. Laird, Study of the Spoil Banks Associated with. Lignite Strip Mining in North Dakota, Misc. Series 24, North Dakota Geological Survey, Grand Forks, 28 pages (1964).

X 301. Dusek, G.L., and S. McCann, Bull Mountains Coal Field St!ldy, Progress Report 1973, State. Fish, and Game Department, Helena, Montana, (in cooperation with Consolidation Coal Company) (July 1973).

Х 302. Goodman, L.E., and C.B. Brown, Dead Load Stresses and the Instability of Slopes, Proc. SM3, American Society of Civil Engineers, pp. 103-134 (May 1963).

Х 303. Hedrick, H.G., and H.A. Wilson, The Rate of Carbon Dioxide Production in a Strip Mine Spoil, Proc: West Virginfa Academy of Science, 28:11-15 (1957).

X304. Hodder, R.L., B.W. Sindelar, J. Bucholz, and D.E. Ryerson, Coal Mine Land Reclamation Research, Research Report 20, Montana Agriculture Experiment Station, Montana State University, Bozeman, 45 pages, illustrations, tables, and appendix (n.d.).

This is a report of research performed by Montana State University in cooperation with the Western Energy Company at a reclamation research site at Colstrip, Montana. The project involved work in the following areas:

1. Development of a standard overburden analysis procedure for determining the chemical and physical properties of overburden and predicting plant productivity on the resultant spoil mater1al.

2. Analysis of mine water to determine trends in water quality.

3. Effectiveness and feasibility of topsoiling and straw-stubble mulching raw spoils.

4. Development of optimum fertilizer rates for revegetating mine spoils.

5. Development of mechanical surface manipulation techniques for erosion control, improved soil moisture availability and improved vegetative cover.

X 305. Hodder, R.L., B.W. Sindelar, J. Bucholiz, and D.E. Ryerson, Surface Mined Land Reclamation Research in Eastern Montana, Research and Applied Technology Symposium on Mined-Land Reclamation, Pittsburgh, Penn., pp. 82-91 (March 7-8, 1973).

Reclamation research in eastern Montana is reviewed, developing technologies are assessed in terms of future potential, and possible 
future needs are oullined. Premining planning that incorporates a comprehensive development plan and schedule of mining and reclamation operations is sees as imperative for the effective management of resource extraction and postreclamation land use. The relative values of various spoil manipulation techniques are evaluated for erosion control and moisture retention. Dry-planting techniques such as condensation traps, supplemental root transplanting, and use of tubelings are assessed in terms of their possible success for revegetation efforts.

$d^{N R} 306$.

Packer, P.E., Rehabilitation Potentials and Limitations of SurfaceMine Land in the Northern Great Plains, General Technical Report INT-14, USDA Forest Service, Intermountain Forest and Range Experiment Station, Ogden, Utah, 44 pages, 2 plates in pocket (1974).

This report is an examination of the constraints on rehabilitation of strip mined land in the northern Great Plains region. The author has defined 146 areas in 86 different classes of rehabilitation-response units. Rebabilitation-response units are represented by a three-part code, where the first part is an Aandahl soil association number, the second is a vegetative type, and the third is the precipitation zone in which the area lies. Rehabilitation-response unit 117-6-14 is, then, a surface-minable tract located in Ustic Aridisol association 117, on grassland-sagebrush type 6, in a 14-inch precipitation zone. Areas of the various rehabilitation-response untts are shown on a map (Plate 8), in conjunction with areas of surface-minable coal. The report is quite technical and requires a background in agronomy to derive the most benefit from it.

307. Pennington, D., ReZationship of Ground-Water Movement and Strip Mine Reclomation, Third Symposium on Surface Mining and Reclamation, Louisville, Ky., I:170-178 (Oct. 21-23, 1975).

$\chi_{308 .}$ Progress Report -- Research on Reclamation of Strip-Mined Lands in Northern Great Plains, Northern Great Plains Research Center, Agriculture Research Center (U.S. Department of Agriculture) Mandan, N.D. (n.d.)

Successful reclamation of mined lands in the Northern Great Plains is dependent upon enhanced revegetation. Soil amendments such as gypsum treatment, topsoiling, mulching to treat problems specific to the west (high SAR values, high salinity, low infiltration) are structured to arrive at proper combinations for intended postmining land use. Tentative conclusions of research still in progress are that cold-season grasses can be established with suitable treatments and with soil amendments and fertilizer designed to combat those spoil properties ruinous to plant growth. Overall, this report treats the properties of overburden and spoils and their effect on plant growth in a technical manner and requires some expertise in soil and plant sciences for comprehension.

Rehabilitation Potential of Western Coal Lands, National Academy of Sciences, Ballinger Publishing Company, Cambridge, Mass. (1974).

Dealing primarily with environmental problems surrounding the mining and reclamation of western coal, the scope of this report is 
much broader. It provides necessary background data and information required as national energy need focuses on the Great Plains and Rocky: Mountain states. An astounding statistic quickly revealed by the Study Committee is that only 92,000 acres by 1990 and an additional 82,000 acres by the year 2000, need to be mined to meet energy demands. Most of the coal reserves are located in semiarid climates having approximately 10 inches of rain per year. This is regarded as a minimum for successful reclamation without extensive irrigation. Also discussed are mine planning, site and reglonal geological investigations, topsoil handling, and revegetation. Studies were made on mining disruptions of aquifers and their effect on the avallability of groundwater. Limitations and weaknesses are illuminated by a serles of critical reviews published with the report. Excellent tabular and graphic data and illustrations are provided. The material is nontechrical and may be of use to planners.

310. Resource and Potential Reclamation Evaluation: Otter Creek Study Site, EMRIA Report No. 1, Bureau of Land Management, U.S. Department of the Interior, Montana State Office, Billings (1975).

The purpose of this report is to provide baseline data to enable making the best choice of reclamation procedures to be included in lease stipulatons. The study area is in the Great Plains and receives an average of 14 inches of rain per year, considered adequate for reclamation. The area of the site is approximately 3000 acres and contains about 300 million tons of coal, most of it less than 200 feet deep. Revegetation by suggested plant species, soil amendments, water resource safeguards, and other topics are discussed. Seven core samples were taken; with complete laver analysis tabulated. A multitude of technical information and data on mineral and site characteristics is provided.

311. Scott, M.D., Methods of Selecting Proper Personnel to Conduct Environmental Baseline Studies Required for Reclamation Planning, Third Symposium on Surface Mining and Reclamation, Louisville, Ky., I:70-79 (Oct. 21-23, 1975).

DuP 312. Selner, J.E., Reclamation Research in the Rocky Mountain Foothilzs, Third Symposium on Surface Mining and Reclamation, Louisville, Ky., I :16-20 (Oct. 21-23, 1975).

313. Wali, M.K., The Problem of Land Reclamation Viewed in a Systems Context, Practices and Problems of Land Reclamation in Western North America, University of North Dakota Press, Grand Forks, pp. 1-17 (1975).

The reclamation aspects of coal development in western United States in relation to economics, agriculture, legislation, and soilforming processes are discussed. In considering strip minnng and economics, the external effects of costs and benefits of land use should be weighted in relation to national energy needs. It is suggested that a systems analysis approach be used to investigate the problems of coal development in a holistic and quantitative manner. 
An Investigative flow diagram for revegetation of overburden materials is presented.

314. Wilson, H.A., and G. Stewart, The Number of Bacteria, Fungi, and Actinomycetes in Some Strip-Mine Spoil, Bullet1n 388T, Agricultural Experiment Station, West Virginia University, Morgantown, 15. pages (Feb. 1956). 
THIS PAGE

WAS INTENTIONALLY

LEFT BLANK 


\subsection{GENERAL WORKS}

315. A Balanced Approach to Resource Extraction and Creative Land Development Associated with Open-Pit Copper Mining in Southerm Arizona, College of Architecture and Mines, University of Arizona, Arizona Board of Regents, 1974.

The activities of an open-pit mining operation in Arizona produces disruptions of the earth's surface that seem to stretch from horizon to horizon. İmmense amounts of solid waste are generated. Ore processing consumes sizable amounts of fresh groundwater, which has multiple demands in Arizona's arid climate, and produces tailing ponds that are miles in dimension. Dried tailings produce dust and grit problems and require vegetative screening. After examining numerous existing sites, a number of alternatives in mining procedures and their feasibility are discussed. Generally, solid waste dumps, tailings ponds and waste water are handled in such a way as to yield land for a pre-determined and desirable reuse, such as residential development or wildlife habitat. The study was a joint effort of local government, private industry, and educational institutions. Highly illustrated and written on a non-technical level, it can be very useful to planners and local goverment officials.

316. Ackerman, D.H., Environmental Plooning in Moderm Mineral Development, Mining Congress J:; p. 40 (Apri1 1970).

Augenbaugh, N.B., C.R. Christlansen, and J.J. Scott, Conversion from Quarrying to Underground Mining, in Tenth Forum on the Geology of Industrial Minerals: Proc., Misc. Report No. 1, Ohio Division of Geological Survey, Columbus, pp. 17-24 (1974).

Zoning and environmental restrictions on land usage now make open-pit quarrying more and more difficult, especially near urban areas. One option for quarry operators is to go underground for mineral production. While underground-mining costs are higher than those for open-cut work, there are several compensating advantages. In many cases it is possible to produce the same material underground without affecting land value, and the surface is preserved for industrial, residential, or agricultural purposes. . Proper planning can yield underground mineral extraction using a three-dimensional, modular-room architectural concept to fully exploit secondary space utilization. Prior to the start of underground mining, an operator must make a careful geological engineering study to determine the suitability of the deposit and must prepare a plan for safe and economical mining for the purpose of converting to a secondary usage. While not considering reclamation per se, the author presents a viable alternative where surface land values are high or where access is denied due to preemptive land uses. The article is interesting and informative. 
X 318. Bishko, D., J.R. Dunn, and W.A. Wallace, Planning for Non-Renewable Common Mineral Resources in Urban-Suburban Environs, Open File Report 25-69 (OFR 25-69), Urban-Environmental Studies, Rennselaer Polytechnic Institute, Troy, New York, prepared for Bureau of Mines, U.S: Department of the Interior, Washington, D.C., 243 pages (Oct. 18, 1969).

The purpose of this report is twofold: (1) to delineate in dollar terms, the magnitude of the result of not planning for the consumption of common mineral resources; and (2) to develop a computer simulation model that will provide planners with an indlcation of the effects of decisions affecting these resources. The research was primarily concerned with construction aggregates (sand, gravel, and crushed stone) and the effect of zoning restrictions on these industries. Although the model developed in this research has been destgned specifically for studying common mineral resources, it can be extended to become part of a more general land use mode. Furthermore, the ideas and methodology used in its development can be applied to studying any nonrenewable, fixed position resource. The report requires, and assumes, a modicum of fomiliarity with simulation modeling techniques.

X 319. Burner, c.C., Fishery Management in Stwip Mine Lakes, paper presented before the Research and Applied Technology Symposium on Mined-Land Reclamation, Pittsburgh, Penn., pp. 304-318 (March 7-8, 1973).

PUP320. Calhoun, D., W.C. Ackerman, and E.H. Armstrong, Comprehensive PZanning for Mineral Resource Development in the Powder River Basin: A Proposal, paper presented before the Second Research and Applied Technology Symposium on Mined-Land Reclamation, Louisville, Ky., pp. 69-75 (Oct. 1974).

Offering general information on mineral resources in the Powder River Basin, this article also provides new approaches to planning and reclamation procedures at the management level. A planning system would include a detailed land analysis, drawing heavily upon the earth science disciplines, and an economic profile for the most profitable longer term use. The authors view the nation's natural resources as declining and favor strong new legislation. to establish protective measures.

DUP 321. Carter, R.P., J.R. LaFevers, E.J. Croke, A.S. Kennedy, and S.D. Zellmer, Surface Mined Land in the Midwest: A Regional Perspective for Reclamation Planning, ANL/ES-43, prepared by Energy and Environmental Systems Division, Argonne National Laboratory for U.S. Bureau of Mines, Department of the Interior, Washington, D.C. 691 pages (June 1974).

The report addresses the problems of coal extraction and surface mine reclamation in the 11-state Midwestern coal resource region. Current and past technologies, practices, production, and regulations are evaluated and recommendations made as to future research efforts. Reclamation problems, practices, and planning are assessed in detail for five states: Illinois, Indlana, western Kentucky, Missouri, and Ohio. The study is an in-depth effort to provide data and direction to planning for surface mine reclamation in the Midwest. The effect- 
iveness of previous and existing controls in encouraging improved reclamation practices is assessed. The report is directed toward government officials and planners.

D $P^{322 .}$ Clouston, J.B., and Ross Anderson, The British Experience in Mined Land Reclamation and Preplanning of Mineral Workings, paper presented before the Second Research and Applied Technology Symposium on MinedLand Reclamation, Louisville, Ky., pp. 217-241 (Oct. 1974).

Unlike the U.S.A., the reclamation of .strip-mined coal land has been government policy for the past 30 years. The National Coal Board restoration techniques are acknowledged to be the most advanced in the world, and require careful management of topsoil and subsoll, contouring spoil piles to match surrounding terrain, and improvement of drainage patterns. The U.K. reclamation problem largely involves clearing up land abandoned by industry. Derelict lands present complex problems and no matter how careful site investigations are, unknowns commonly arise. Detailed consideration must be given to land form design, bulk earthmoving, drainage design, revegetation, and adequate after-care.

323. Coates, W.E., Landscape Architectural Approach to Surface Mining Reclamation, paper presented before the Research and Applied Technology Symposium on Mined Land Reclamation, Pittsburgh, Penn., pp. 26-41 (March 1973).

A new philosophy regarding strip mining and reclamation is urged by the author, an engineer and landscape architect. In this he calls for an approach to stripping and reclamation that involves comprehensive operational and rehabilitation planning before the commencement of mining operations. A part of this.planning calls for the defining of noncommercial deposits, and an interim zoning or holding status for those that may become commercially valuable in the future due to price increases. The acquisition of adequate base information for planning is emphasized. Proposals for new operating techniques are made, involving overburden segregation and alterations of traditional load and haul techniques. The author suggests using the mine floor for spoil. storage rather than as a haul road. A dual purpose bucket-wheel excavator is proposed to remove overburden and coal simultaneously, with separate conveyors for spoil placement and coal loading. The author discusses technical information in a nontechnical way, and is easily understandoble.

324. Copeland, O.L., and P.E. Packer, Land Use Aspects of the Energy Crisis and Western Mining, J. of Forestry, p. 70 (Nov. 1972).

325. Cornforth, C.L., Reclamation Commitment Proves Rewarding, Coal Mining and Processing, 10:32-36 (March 1973).

Environmental Planning and Geoiogy, U.S. Geological Survey, Department of the Interior and the Office of Research and Technology, U:S. Department of Housing and Urban Development, U.S. Government Printing Office, Washington, D.C. (1970). 
The proceedings of the Symposium on Engineering Geology in the Urban Environment arranged by the Association of Engineering Geologists in October of 1969 is presented in this publication. In general, the articles within the proceedings consider the application of earth science data to planning for urban areas. Of interest to urban planners is the identification of rock formation, land slide areas, and fault lines in the earth's crust in determining zoning and building codes. The papers are technical, planning-omiented, and provide useful information.

327. Fowler, D:K., and C.H. Perry, Three Years' Development of a Public Use Wildlife Area on a Mountain Coal Surface Mine in Southwest Virginia, Research and Applied Technology Symposium on Mined-Land Reclamation, sponsored by the National Coal Association, P1ttsburgh, Penn., pp. 319333 (March 1973).

This is a technical report of experimental efforts to reclaim strip mined areas to maximum benefit for wlldlife and to protect the land from fire and erosion. Performance of numerous reintroduced flor a and fauna is evaluated.

Х328. Friz, T.0., Mineral Resources, Mining and Land-Use Planning in Wisconsin, Circ. 26, Geological and Natural History Survey, University of Wisconsin Extension (1975).

This report provides background information that can be used by individuals, local and state governments, industry and planning units as the basis for assessing concerns over matters such as rising mineral costs, mining methods, reclamation, and land use conflicts.

It gives general background information and answers to questions on Wisconsin's minerals, mineral deposits, mineral economics, mineral production, mined land reclamation, and mining and mineral resources as related to land use planning. It also describes the nature of occurrence and distribution of mineral deposits, the value of the mineral industry, how minerals are produced, reclamation of mined land, and mining as a temporary use of land that can be made a part of a multisequential land use plan.

329. Glover, H.G., Coal Mine Refuse Disposal in Great Britain, Special Research Report No. S.R. 81, Department of Environmental Resources, Pennsylvania State University, Unfversity Park, (March 1971).

The British experience in land reclamation is reported in this document. Derelict land composed of large tracts of excavated land and refuse piles totalled 150,000 in 1964. The limited availability of land and the high population densities in mining districts brought about stricter law enforcement in the late forties and fiftles. The costs of reclamation efforts are supported by public funds. Today few refuse banks emit more than a slight odor and all excavations have been restored. The report is intended for surface mine operators and regional or environmental planners. 
X30. Goodwin, F.W., Plooning for Mining of Construction Materials, Federation Planning Information, New Jersey Federation of Planning Officials, Mountainside, N.J., II(5) (Nov. 1967).

The role of planning in the wise use of mineral resources is discussed in this brief report. The author provides a ..review of the effectiveness of regulations and performance standards, and outlines an approach to planning for surface mining and rehabilitation from a regional viewpoint. Emphasis is placed on the need to return to productive use for community and private pruposes. The report is intended for the planner dealing with surface mining in a local setting and attempts to provide a rationale for the development of effective plans that include intelligent resource use.

331. Greenwald, E.H., Jr., A Landscape Architect Looks at Site Planning for Mines, Mining Congress J., pp. 80-85 (June 1976).

The author, a landscape architect, presents a "design process" that can be used for planning site development and surface facilities of coal mines. The "design process" consists of six phases that include program definition, site analysis, master plan development, schematic design, design development, and contract documents/field services. Each ". of the six phases are broken down into subphases.

This "design process" method was used in the development of a master plan for a proposed deep mine in southwestern Pennsylvania. The author outlines the Pennsylvania site development.

This short article might be useful as a general outline for mine and/or zand use planners who are confronted with problems of mine development.

Grim, E.C., and R.D. Hill, Environmental Protection in Surface Mining of Coal, Environmental Protection Technology Series, EPA-670/2-74-093, U.S. Environmental Protection Agency, Cincinnati, Ohio, 277 pages (Oct. 1974).

This report emphasizes premining planning and the integration of surface mining and reclamation operations for increased efficiency and effectiveness. Strip and auger mining methods and equipment are described and their advantages or disadvantages are evaluated in terms of operating efficiency and potential for simultaneous mining and reclamation procedures. Recommendations are made that new techniques be used that will maximize aesthetic potentials of reclaimed spoil banks and reduce the dangers of erosion, landslide, and water pollution. Reclamation methods discussed include spoil segregation and placement, topsoiling, grading, burying of toxic spoil materials, and revegetation. Blasting techniques designed to reduce vibrational damage to structures are outlined. Haul road design and maintenance for erosion control and sediment reduction is considered in detail. A detailed discussion is also presented on methods for the control of spoil bank erosion by spoil manipulation techniques, diversion ditches, and check dams. Revegetation and acid mine drainage problems are outlined; and methods 
and techniques for effective cover establishment and spoil stabilization are recommended. One chapter is devoted to a view of reclamation costs, including backfilling, grading and revegetation. Appendices present guidelines for planning, location, construction, maintenance and abandonment of coal-haul roads and drainage structures. Referenccs are listed at the end of each section, and future research needs are highlighted in a separate section. The report is well written and constitutes $a$ basic reference in the literature on surface mining and reclamation.

333. Gunnett, J.W., Regional Aspects of Mine Planning to Increase Production and Enhonce Reclamation, Third Symposium on Surface Mining and Reclamation, Louisville, Ky., I:95-127 (Oct. 21-23, 1975).

This is a summarization of the principal points of Economic Engineering Analysis of U.S. Surface Coal Mines and Effective Reclamation, prepared for the U.S. Bureau of Mines by Skelly and Loy, consulting engineers. Cost factors are presented for each phase of surface mining technique. Aids for planning and development decision-making are discussed. The report is quite technical, but the cost data are useful, as are discussions of the relative advantages and disadvantages of the several surface mining techniques.

Herricks, E.E., John Cairns, Jr., and V:O. Shanholtz, Preplanning Mining Operations to Reduce the Environmental Impact of Mine Drainage on Streams, Proc. No. 18, Water Resources Problems Related to Mining, American Water Resources Association (June 1974).

The authors have developed and applied hydrologic and water quality models to a typical mine drainage situation. This technique provides a low cost : method of environmental data acquisition, encouraging development of a data base to include streams and rivers in preoperational planning efforts. 'l'he models developed provide a tool to predict mine drainage loadings, water quality alteration, and overall environmental impact.

The article is general in nature, but suggests an interesting approach to reclamation planning that includes the assessment of potential iffluents.

335. Higgins, Tom, The Plonning and Economics of Mined-Land Use for Agricul.tural Purposes, paper presented before Research and Applied Technology Symposium on Mined-Land Reclamation, Pittsbur.gh, Penn., pp. 287-293 (March 1973).

Procedures for reclaiming strip mined land for agricultural purposes are outlined. Grading, seeding, spoil treatment techniques, and their coordination are aired in a cursory manner. Results of experimentation with varlous agricultural land uses show that reclaimed pasture land provides the most promising return on investments.

336. Hines, B.J., H.W. Everett, C.A. Foster, Meeting the ChalZenge of Reclamation, Second Research and Applied Technology Symposium on MinedLand Reclamation, pp. 101-105 (Oct. 1974). 
Using strip mining experience gained in Kentucky coalfields, the authors examine the range of possible environmental damages. Remedies to these are careful planning of mine operations, erosion prevention measures, concurrent reclamation, and effective revegetation. A rigid law requiring recontouring of mined land to match surrounding terrain is discouraged on the basis that the landowner's future plans for the land must be taken into account. For instance, in mountainous areas level land is highly prized and coal haul roads can be important access routes. Mine operators in Kentucky are urged to ask the Soil Conservation Service for technical assistance on revegetation, drainage, and other related matters before mining starts.

337. Hole, W.E., Jr., Conservation and Reclamation in the Sand and Gravel Industry, Tenth Forum on Geology of Industrial Minerals, Proc., Misc. Report Nio. 1, Division of Geological Survey, Ohio Department of Natural Resources, Columbus, pp. 1-5 (1974).

The sand and gravel industry provides an enormous quantity of materials vital to the maintenance of low-cost construction. There has been little effort to conserve this valuable material resource. In fact, existing regulations that affect sand and gravel operations act more to waste these materials than to conserve them. Another factor affecting the industry is new leglslation requiring the reclamation of worked-out pits. Although such legislation creates many administrative headaches for a sand and gravel operator, the possibility exists, through such legislation, of gaining conservation measures that could be helpful to the industry as a whole.

338. Holmberg, George, William Horvath, and J.R. LaFevers, Citizens Role in Land Disturbance and Reclamation, paper presented before the Symposium on Reclamation of Drastically Disturbed Lands, Ohio Agricultural Research and Development Center, Wooster, Ohio (Aug. 1976).

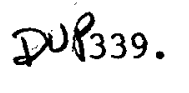

Imhoff, E.A.,'T.0. Friz, and J.R. LaFevers, A Guide to State Programs for the Reclamation of Surface Mined Areas, Circ. 731, Resource and Land Investigations (RALI) Program, U.S. Geological Survey, Department of the Interior, Arlington, Va., 33 pages (1976).

During 1975, inquiries of agencies in each state and review of state statutes and related administrative codes revealed that 38 states have established programs requiring the reclamation of surface mined lands. Results of analyses of those programs and ancillary data are presented in: (1) a table (matrix) designed for the notation and elaboration of information pertaining to the mined-area reclamation programs of the 50 states; (2) a primer on surface mining activities and related reclamation practices and problems; and (3) a listing of types of non-federal governmental controls applicable to reclamtion. Interpretations of the status and content of state programs suggest. that although a common thread runs through state statutory language, administrative requirements vary from state to state in order to meet different natural, economic, social, and political considerations. A general trend is seen in state programs toward the..requiring of an integration of land-use planning and mine planning, with increased 
local government involvement. The circular is directed toward the needs of planners in determining administrative controls and programs applicable to planning and reclamation in their respective areas of responsibility.

340. Krause, R.R., Equipment and Extractive Advances; Spoiz Stratification, Coal Mine Spoil Reclamation; Scientific Planning for Regional Beauty and Prosperity, Proc., School of Forest Resources Sympostum, October 1213, 1965, School of Forest Resources, College of Agriculture, Pennsylvania State University, University Park, pp. 77-81 (1965).

Reclomation, Proc.,' Conference on the Interaction of Urbanization and the Mineral Industries, Ohio State University, Columbus, Natural Resources Institute, Annual Symposium, pp. 71-76 (1965).

Larkin, R.P., G.L. Peters, and J.S. Spicer, Anthracite Refuse Pollution and Socio-Economic Planning in Northeastern Pennsylvania, Special Research Report, No. SR 90, Department of Environmental Resources, Pennsylvania State University, University Park, (Feb. 1972).

This study was initiated to determine a rational planning procedure in cleaning up anthracite refuse piles in the Northeastern Pennsylvania coalfields. A rating was established to determine visual detriment of the gob pile. Other factors used to establish removal priority are air pollution due to combustion of the refuse piles, volume to area ratios, and surrounding land values. These socioeconomic variables were evaluated by data matrix and vector methods to determine removal priorities. The authors hope to include cost benefit analysis in the future. The report is readable and useful within the anthracite mining district.

Leonard, M.R., Assets that Can Become Liabilities, Tenth Forum on the Geology of Industrial Minerals, Proc., Misc. Report No. 1, Division of Geological Survey, Columbus, Ohio, pp. 10-12 (1974).

The author describes the experience of the Standard Slag Company of Youngstown, Ohio, in attempting to convert a worked-out quarry into a sanitary landfill site. The reason for failure was attributed to the inability to obtain a zoning change from township officials.

X344. LaFevers, J.R., Effects of Legiszative Changes on the Reclamation of Surface Mined Land in the Southwest, Proc., Symposium on Disturbed Land Reclamation and Use in the Southwest, University of Arizona Press, Tucson (Jan. 1976).

Maneval, D., Reciaiming Land for Recreational Development, Part I, Coal Mining and Processing, 12:84-86 (Apri1 1975).

This publication discusses the possibilities and benefits of turning strip mined land into recreational land uses. Premining planning can enhance reclamation activitles and eliminate excessive handling of spoil material. The article also lists various agencies 
that could give technical and financial assistance to communities or planning agencies that encounter problems associated with strip mined land. The language in this article is not technical.

346. Part 2, Coal Mining and Processing, 12:74-76 (June 1975).

This work briefly describes several reclamation projects associated with strip mined land in Pennsylvania. Most of these projects have taken advantage of bodies of water that have been created as a result of the mining operation. Recreational and residential land uses are usually the highest form of development that can take place on formerly mined land. The article also mentions a couple of techniques that can be implemented to reduce or eliminate future water pollution problems.

This publication is not technical in nature, and provides useful background information.

347. Martinka, P.D., C. A. Keffler, Central Ohio Coal Company's Mine. Expansion Program, Case Studies of Surface Mining, Proc., 2nd International Surface Mining Conference, Minneapolis, Sept. 18-20, 1968, American Institute of Mining, Metallurgical, and Petroleum Engineers, New York, pp. 36-46 (1969).

In this case study of the mining operations in southeastern ohio, problems of coal extraction are analyzed. The mine planning is discussed with respect to mining conditions and possible coal extraction alternatives. The study briefly analyzes land reclamation and its multiple uses.

A knowledge of coal mining terminology would be helpful in the comprehension of this study.

348. Meshenberg. M.J., Environmental Planning: I. Environmental Information for Policy Formulation, Report No. 263, Planning Advisory Service, American Society of Planning Officials, Chicago, 52 pages (Nov. 1970).

The purposes of this report are to show why quality of the environment should be given greater attention in the planning process than it has in the past and to describe the data that should be collected and analyzed for inclusion in the comprehensive plan. The authors' main premise is that conservation and development are not mutually exclusive; that when conservation is considered as part of the development process, the likellhood of long-term success is improved. This report contains background information intended for use by land use planners.

349. Miller, E. L., and J. R. DeTuerk, A Landscape Architectural Approach to Reclamation and Development of Deep Anthracite Strip Pits, Special Research Report No. SR-68, Coal Research Section, College of Earth and Mineral Sciences, Pennsylvania State University, University Park, Penn. (n.d.).

The basic intent of this study is to find a common approach based upon the relationship of compatible land uses and to relate 
these uses to deep strip pit areas, local and statewide transportation systems, and state and local parks, as well as to the economic bases of individual communities in Pennsylvania.

In this investigation, landscape characteristics that exist in the devastated areas of the anthracte region were analyzed and categories established.

This is a largely graphic document intended for use by planners and general readers alike.

350. Mining's Green Thumb; Mine Plan for Total Resource Management, Engineering and Mining J., 168:72-82 (Ju1y 1967).

351. Montgomery, H.B., Land Use Planning of Surface Mined Land, Symposium on Surface Mine Reclamation and Land Use Planaing, Lee College, Jackson, V Ky., sponsored by Scientists and Engineers for Appalachia. (Oct. 1973).

This article discusses the success of land reclamation practices in regard to the following aspects:

Geographic range of the mined land, Time span of projects; Significance of project, and Quantitiy/quality of information. engineer.

This article is intended for the land-use planner or mining

352. Moran, Stephen, G.H. Groenwald, L. Hemish, and C. Anderson, Development of a Pre-Mining Geological Framework for Landscape Design Reclamation

in North Dakota, Proc., Fort Union Coal Field Symposium, Montana Academy of Sciences, Billings, Vol. 3 of 5 volumes, pp. 308-216, (April 25-26, 1975).

The authors emphasize the importance of adequate premining studies of soils and geology to determine overburden characteristics and possible future reclamation problems. A computer model for reclamation landscape design is briefly discussed. The model, under development, is designed to utilize premining data inputs to determine optimal reclamation procedures in light of various scenarios. The article, as a symposium paper, is addressed to an audience with a wide range of technical and nontechnical backgrounds.'

353. Paller, William, and D.A. Schultz, Planning Approaches to Surface Mining on the National Forests, paper-presented before..Research and Applied Technology Symposium on Mined-Land Reclamation, Pittsburgh, Penn., pp. 68-81 (March 1973).

The paper is a report of the U.S. Forest Service's experience at Caribou National Forest with the premining planning of phosphate mining in conjunction with the operating company for the protection of adjacent areas and reclamation.'A five-year plan was developed that 
outlined operational procedures and responsibilities; and provided for concurrent rehabilitation of the mined area. Rehabilitation was to conform to a plan agreed upon by the Forest Service and company officials, designed to return the surface mined area to use as wildlife range, with impoundments for the establishment of fish habitats. The primary emphasis is on the need for detailed pre-operational inventories and planning, with design criteria well established before mining begins. Potential difficulties that might result from mining are discussed, including potential for disruption of groundwater hydrology, timber losses, and habitat losses. Project SEAM (Science, Environment, Administration, and Minerals) is a concerted effort by Forest Service research and administration arms to find solutions to the pressing problems of mineral needs and resource conservation. Remote sensing is also touched upon, with notè made of its value for monitoring compliance to lease terms and for assessment of resources that might become avallable to meet future needs.

354. Paone, J., J.L. Morning, and L. Giorgetti, Land UtiZization and Reclomation in the Mining Industry, 1930-71, IC 8642, Division Ferrous Metals-Mineral Supply, U.S: Department of the Interior, Bureau of Mines, Washington, D.C., 61 pages, illustrations, and tables.

Statistics relating to mineral extraction by surface-mining methods are presented by state and commodity. Data are given for land utilized for wastes from mining and mill operations, and for land reclaimed from these uses.

Land utilized by the mining industry from 1930 through 1971 amounted to 3.65 million acres, or $0.16 \%$ of the land mass of the United States. Land reclaimed during the same period was 1.46 million acres, or about $40 \%$ of the land utilized. This report includes data on land use for wastes from mill operations and subsidence. Data on land use and reclamation were obtained from operating companies, mining organizations, appropriate state agencies, and others concerend with such activities. The 10 leading states in land used for mining in 1970 were, in decreasing order: Kentucky, Pennsylvania, Arizona, Ohio, California, Florida, West Virginia, Illinois, Minnestoa, and Indiana. Mineral commodities accounting for a major portion of land use are, in decreasing order: bituminous coal, sand and gravel, stone, copper, phosphate rock, iron ore, and clay; except for coal, these commodities are produced principally by surface mining operations.

Reclamation over the 42-year period was largely on lands utilized for suface mining of bituminous coal. New surface mining methods, particularly for coal, incorporate some form of land restoration. This study is principally statistical in nature, but intended for the average reader. 
355. Persse, T.H., Strip Mining Techniques to Minimize Environmental Damage in the Upper Missoum River Basin'States, Preliminary Report No. 192, Bureau of Mines, U.S. Department of the Interior, Washington, D.C., 52 pages (1973).

To meet escalating energy requirements, substantial increases in production from the strippable coal and lignite deposits in eastern Montana, western North Dakota, and north eastern Wyoming already have occurrred, and further expansions are expected, at least until the year 2000 . Such production, attributable largely to rising demand for low sulfur coal, must be accomplished with a minimum of adverse effects on the environment. Information on geology, climate, and current land use in the Upper Missouri River basin is presented in the Bureau of Mines review as a guideline to what operators may expect during and after mining. Proven methods of protecting the air and water pollution and of restoring mined land for other uses are described, and untried methods of land reclamation, some with equipment yet to be manufactured, are discussed as possible means of maintaining aesthetic values in the basin.

356. Peters, J.W., T.S. Spicer, and H. L. Lovell, A Survey of the Location Magnitude, Characteristics and Potential Uses of Pennsylvania Anthracite Refuse, Pennsylvania. Special Report SR 67, Coal Research Board, Department of Mining, Pennsylvania State University, University Park, (Jan. 1968).

The impact of anthracite industry refuse piles in northeastern Pennsylvania on the public requires corrective action. A large volume of data is presented showing refuse bank location and quantities. This study finds large amounts of recoverable coal a possible source of low cost power, and provides technical knowledge and graphic displays of methods of separation. The technical quality of the report is at the engineering level.

357. Pickels, George, Realizing the Recreation Potential of Sand and Gravel Sites, National Sand and Gravel Association, Silver Spring, Md. (1968).

The sand and gravel industry can provide cheap construction material if large tracts of reserves are kept from other preemptive uses near population centers. Careful planning of site development can provide concurrent and post-operational recreation areas. Often extractive and processing operations will last from 15 to 30 years. With adequate screening, adjacent unmined land can be used for outdoor recreation with the industry volunteering construction of park facilities. Possible uses of a depleted site are numerous and depend upon site characteristics and community needs. This booklet is generally nontechnical and intended for planners, local goverment officials and mine operators.

Preplanning: Surface Mining for Outdoor Recreation, U.S. Department of the Interior, Bureau of Outdoor Recreation, Washington, D.C. (n.d.)

Beginning with a review of the reclamation program at Friendship Park, Jefferson County, Ohio, the role and need for preplanning in 
strip mine reclamation for recreational purposes is presented in brief. Various types of land uses for reclaimed land are outlined and conservation measures for each are briefly discussed. A very brlef outline of possible sources of assistance for strip mine reclamtion is given. The booklet is intended for the general reader and public administrators.

X359. Reclamation Factors to Keep in Mind when Planning a Surface Mine Operation, Coal Age (Nov. 1974).

Premine planning in regard to reclamation is the main theme of this article. Informational needs are discussed involving acidity, erosion, drainage area, and many other topics associated with coal mining and reclamation.

This nontechnical article is intended for planners and practitioners in the coal mining industry.

360. Reilly, J.D., Planning Surface Mine Reclamation before Mining, Mining $\checkmark$ Congress J., 51:93-96 (Nov. 1965).

361. Riley, C.V., Ecology -- Ally of Mined Land Restoration, paper presented $P$ before Second Research and Applied Technology Symposium on Mined-Land DMP Reclamation, Louisville, Ky., pp. 54-68 (Oct. 1974).

362. Schellie, K.L., and A.M. Bauer, Shaping the Land: Planned Use of Industrial Sand Deposits, National Sand and Gravel Association, Silver Spring, Md. (1968).

The historical and current background of the industrial sand industry is reviewed in light of extractive methods, processing, reclamation, and their respective impact on land use. A careful distinction is drawn between reclamation and Planned Extraction and Development. The authors examine potential land uses and planning procedures designed to realize predetermined postmining and land use goals. The importance of premining studies and site planning to reduce reclamation costs and improve extraction efficiency is emphasized. The development of a Master Plan during the early stages is recommended, with input from local and regional officials:

The publication is informational in nature and can be easily understood by the interested individual without a technical background.

363. Schellie, K.L., and D.A. Roger, Site Utilization and Rehabilitation Practices for Sand and Gravel Operations, National Sand and Gravel Association, Silver Spring, Md. (1973).

Directed at the sand and gravel producer, this volume is presented as a guide for preplanning the useful adaptation of land after extraction of sand and gravel. With projected growth levels of the nation, it is the problem of the sand and gravel industry to get community acceptance in establishing new sites and reserving resource-rich areas for future growth by participating in zoning law modifications. This objective is possible through cooperation with community land use planning authorities 
and by the planning of mine sites to yield land features that are amenable to commuity needs. Dozens of possible land uses are explored, many of which are recreational in nature. Soils and plant nutients are studied. Highly informative maps based on climate and temperature split the nation into regions, indicating the trees, shrubs, and grasses natural to that area and give tree growth data for numerous species for the purposes of screening and revegetation of mine sites. The report is intended for use by producers, planners, and the interested public.

364. Schellie, K.L., Influence of Geology on Pit and Quarry Reuse Planning, Tenth Forum on Geology of Industrial Minerals Proc., Division of Geological Survey, Ohio Department of Natural Resources, Columbus, pp. 6-9 (1974).

This paper excmines the importance of adequate geological invertigation to premining planning for the reclamation of sand and gravel pits. A study is described that involved several consultants and conflicts of professional opinions relating to the geology of a technically complex area in Orange County, California. County reclamation requirements are considered in light of geologic realities and possible land use.

365. Shackleton, R.D., and K.C. Roberts, Medusa's RecLamation Programs in Three States, Tenth Forum on the Geology of Industrial Minerals, Division of Geological Survey, Ohio Department of Natural Resources, Columbus, pp. 13-16 (1974).

This paper deals with various state laws regulating mining and reclamation in Georgia, Illinois, and Pennsylvania, where the Medusa Cement Company has quarries. Recommendations are made for future changes in state laws particularly as pertains to bonding, fees, period between mining and reclamation, plans required, buffer zone, and renewal times. The paper is excellent for obtaining an idea of the complexity of requirements in various states.

366. Sources of Assistance in Reclaiming Surface-Mined Land for Outdoor Recreation, Bureau of Outdoor Recreation, U.S. Department of the Interior, Washington, D.C. (1975).

This publication constitutes a list of the major sources of assistance to public and private interest involved in, or contemplating, the restoration of strip mined sites for recreational uses. Federal, state, and local sources of financial and technical assistance are listed or commented upon. Private organizations offering or having available funds or personnel for aid in reclamation planning are also noted. With most organizational listings, the reader is referred to further material that may be of help, either in the planning of a reclamation project or in locating specific offices where assistance may be obtained. Intended for use by land use planners, public officials, and the general public.

367. Spore, R.L., Evaluation of Alternative Land Uses: Coal Surface Mining vs. Natural Environment Preservation, Regulation of Surface Mining, U.S. Senate Committee on Interior and Insular Affairs, 93rd Congress, Part II, Serial No. 93-11, U.S. Government Printing office, Washington, D.C., pp. 1287-1294 (1973). 
368. Stamm, G.G., Preplanning for Coal Production and Reclamation of Mined Lands, Third Symposium on Surface Mining and Reclamation, Louisville, Ky., I:62-69 (Oct. 21-23, 1975).<smiles>CC(=O)C1CCCCC1</smiles>

The article is a discussion of water problems relative to western coal development. Related federal studies and programs are outlined. The Bureau of Reclamation's role in planning for surface mining and reclamation in the western states is discussed:

The paper is intended for the general reader and is nontechnical. Note of existing studies should be made by those involved in planning for surface mine reclamation in the western states.

Х369.

Surface Mining of Coal in the Region -- Gallatin and Saline Counties, Southeastern Illinois Regional Planning and Development Commission, Harrisburg, I1l., 13 pages, maps, tables (Aug. 1974).

This report attempts to bring together strip-coal-mining data from several sources for the southeastern Illinois region, particularly Gallatin and Saline Counties, the only ones experiencing surface mine. activity. The current status of surface mining in the two counties is evaluated and projections of future mining are made. The study is a background report sponsored by the Illinois Department of Local Government Affairs for planning purposes. It is designed for use by planners and interested citizens.

370. Tandy, C.R.V., Reclamation of Derelict Land at"Stoke-on-Trent, Proceedings of the Fourth Minera1 Waste Utilization Symposium, Chicago, May 7-8, pp. 284-293.

The Central Government of the United Kingdom encourages local authorities to reclaim derelict land for recreation and other (unprofitable) purposes by paying generous grants on the cost of the work. The Borough Authority with the largest area of dereliction, Stoke-on-Trent, is also the one that has done the greatest amount of reclamation work. Described are the concepts of pedestrian greenways on derelict railway lines, and of a central forest park, which inspired the local council to proceed with a large number of projects. These included a complete facelift for the city and the development of playing pitches, swimming and boating lakes, and nature reserves on the sites of derelict industry. Most of the land is composed of old colliery shale tips or worked out claypits. No topsoil is used, but the ground is reshaped, cultivated, and planted with mixtures of indigenous plants. The result is not a group of highly maintained municipal parks - but wedges of natural looking landscape penetrating the city. There have been problems of management but successful results are now being achieved after 5 years.

371. Thirgood, J.V., PZanned Reclamation, paper presented before the Research and Applied Technology Symposium on Mined Land Reclamation, Pittsburgh, Penn., pp. 92-97 (March 7-8, 1973).

Reclamation is an integral part of the mining enterprise and as such requires prior planning as careful as the mining operation itself. In the words of the author: 
Reclamation involves three distinct phases:

i. prior land use planning including an inventory of land and water resources before mining,

ii. physical operations to achieve a suitable topography, and

iii. natural and assisted revegetation, and subsequent management of reclaimed land.

The importance of effective communication between those involved in reclomation is emphasized, particularly between reclamation personnel and mining engineers. Based on the author's experience in British Columbia, a greater coordination of effort is needed between companies and authorities responsible for compliance with regulatory requirements.

372. Whitney, E.D., L.L. Hench, and B.P. Cason, Use of Surface Interactions in the Solving of Florida Mining and Materials Problems, College of

Engineering Experiment Station Report, University of Florida, 34 pages (June 30, 1972).

373. Whitt, D.M., After the Mining -- Useful Land, Mining Congress J., 56:27-29 (May 1970).

374. Zande, R.D., Friendship Park -- One Use of Reclaimed Strip Mine Land, paper presented before Research and Applied Technology Symposium on Mined-Land Reclamation, Pittsburgh, Penn., pp. 294-303 (1973).

Near Steubenville, Ohio, surface-mined lands were reclaimed to provide a very impressive and badly needed year-round recreational facility. Aided by premining planning on the part of mine officials, engineering projects include the largest earth-fill dam in Ohio, an airport, fairgrounds, and other features. Funding, cost estimates, and future park income are indicated. The paper provides an insight into what can be done when careful planning and community-company cooperation are joined.

\section{(6.2 INTEGRATED LAND-USE AND RECLAMATION PLANNING PROCEDURES AND GUIDELINES \\ 375. A Guide for Revegetating Bituminous Strip-Mine Spoils in Pennsylvania, Research Committee on Coal Mine Spoil Revegetation in Pennsylvania, Harrisburg, Penn., 46 pages (rev. 1971).}

This is a general guide for the establishment of vegetative cover on strip mine reclamation sites. Pennsylvaiia legislation pertaining to reclamation is reviewed. Consideration is given to classification of spoil types and the potential of each type for revegetation. Careful planning before attempting revegetation is emphasized. Planting methods suitable for various vegetative covers are outlined according to future land use of the reclaimed area. The emphasis is on predetermination of future land use, whether for forest, cropland, wildlife, or recreation. Appendices contain recommendations for seeding, legal constraints: and 
rules governing planting on spoil banks in Pennsylvania, and locations of wildlife plantings on spoil banks in the state. In addition, a selected bibliography of works relating to the revegetation of strip mined areas is provided.

The guide is intended for use by contract planners, mine operators, county extension agents and goverment agency personnel.

376. Bauer, A.M., Simultaneous Excavation and Rehabilitation of Sand and Gravel Sites, National Sand and Gravel Association, Silver Spring, Md. (1967).

Existing practices in the sand and gravel industry are surveyed with emphasis on site location, operational characteristics and current rehabilitation practices. Planning procedures to provide for simultaneous excavation and rehabilitation are recommended and illustrated in case studies. Primary emphasis is placed on postmining land use to meet pre-established goals of future development.

Being relatively nontechnical, the publication is intended for planners and public officials responsibility for land use decision making.

377. Baxter, J.G., Site Planning for Sand and Gravel Operations, National Sand and Gravel Association, Silver Spring, Md. (1969).

Due to the proximity of sand and gravel operations to population. centers, there is much concern within the industry regarding the visual appearance and impact of mining sites on communities. Mining sites can present a public safety hazard, a source of contamination, and can be a nuisance. Visual problems are broken down and clarified. Views can be enhanced by selective screening and orderly equipment arrangement. Problems of more substance such as noise and dust pollution are treated. The public is also concerned with spillage and traffic disruption from haul trucks. The main thrust of this booklet is to outline methods to alleviate these problems and provide information to harmonize site operation with community life. It is intended for use by planners and operators.

378. Deely, D.J., 0.B. Russe11; and F.J. Wobber, Application of Aerial and Orbital Remote Sensing to the Study of Mined Lands, presented before Research and Applied Technology Symposium on Mined-Land Reclamation, Pittsburgh, Penn., pp. 15-25 (1973).

The role of conventional and thermal infra-red photography in the monitoring of strip mined lands is examined, as is the current and future potential of the use of ERTS-1 imagery. The advantages and disadvantages of the various remote sensors are assessed in relation to their value for monitoring purposes and in terms of scale or resolution. The value of remote sensing for reclamation planning is evaluated in detail, and possible sources of imagery are discussed. The report is nontechnical and is designed for planners. 
$\chi_{379}$

Ellison, R.D., and R.G. Almes, Synopsis of Engineering and Design

Manual for Coal Refuse Embankments, paper presented before First Symposium on Mine and Preparation Plane Refuse Disposal, Louisville, Ky., pp. 78-85 (1974).

380. Hanchey, J.R., Public Involvement in the Corps of Engineers Planning Process, I.W.Q. Research Report 75-R4, U.S. Army Engineer Institute for Water Resources, Fort Belvoir, Va. (Oct. 1975).

This report discusses the design, implementation, and management of public involvement programs as an integral part of the Corps of Engineers water resource planning process. The suggested approach to program development relies on several key concepts; first, that planning should be viewed as consisting of several sequential stages, each which has a definable output and therefore represents an impliclt or explicit decicion point; second, that public involvement programs can and should be approached on a stage-by-stage basis; third, that there should be public checkpoints at the end of each stage to provide the public and the reviewing elements of the Corps with citizen input as to the adequacy and responsiveness of the planning to date; fourth, that these public checkpoints are not in thenselves adequate, but are only the culmination of active participation during each planning stage by limited segments of the public; and fifth, that decision-making responsiveness to public concerns requires the explicit consideration of public input before key decisions are made at each level. The report includes chapters on developing public involvement progrons, forms for obtaining citizen input, guidelines for developing public and staff organization, and budgeting for public involvement activities.

381. Jensen, D.R., Selecting Land Use for Sand and Gravel Sites, National Sand and Gravel Association, Silver Spring, Md. (1967).

Criteria and procedures for the selection of postmining land use are discussed and site development procedures are outlined. Potential land uses are examined in terms of their respective requirements and possible future benefits. Fill types and soll comparisons are briefly presented in an appendix.

The report is intended for professional plianners and public officials having zoning or related responsibilities. It is written in an expository, nontechnical manner.

382. Johnson, Craig, Practical Operative Procedures for Progressive Rehabilitation of Sand and Gravel Sites, National Sand and Gravel Association, Silver Spring, Md. (1966).

Equipment characteristics, as used in the sand and gravel industry, are examined in detail. Practical recommendations are made for developing operating procedures that incorporate site rehabilitation into the overall mining operations plan. Processing plant locations and their influence on future development is discussed, along with a sketch of plant refuse disposal techniques. Rehabilitation of a sand and gravel site at Littleton, Colorado, is reviewed in a detailed case study. The report is technical, but understandable for professional planners, and others with a nonengineering background. 
383. Land-State Alternatives for Planning and Management, Council of State Governments, Lexington, Ky. (April 1975).

Difficulties involved with land planning and management clearly extend beyond the boundaries of the communitites in which they happen to be centered. The establishment of state planning authorities appears to be becoming increasingly necessary to avoid conflict between local governments. Citizen participation is an incremental part of state land use planning programs. State development plans will desi.gnate critical areas to insure careful land use. Ideas for planning agency organization and personnel requirements are examined. A study of planning-oriented data systems gives general procedures for data acquisition and use. The flexibility and limitations of principal data sets are considered key characteristics. Overall, the report is an in-depth study aimed at encouraging the involvement of state govermments in land use planning.

384. Lanim, A.E., Role of Coal Industry in Planning and Implementing Development of a State or Regional Program, papers presented, Strip $\sqrt{ }$ Mining Symposium, Owensboro; Ky., 1967, Department of Natural Resources, Division of Reclamation, Frankfort, pp. 41-47 (Ju1.y 13-16, 1967).

385. Manual of Practice for Premining Planning: Eastern Surface Coal Mining, Department of Mineral Engineering, Pennsylvania State University Mining Pollution Contro1 Branch, National Environmental Research Center, U.S. Environmental Protection Agency, Cincinnati, Ohio (in progress).

Preliminary research is documented in this report and the topics of geology, hydrology, land use management, surface mine engineering, federal and state laws and water quality management are examined in terms of applicability to surface mining and reclamation. Knowledge of the earth sciences is a necessity to digest the material presented. The ramification of usable soil above coal seams is investigated. Overall, much valuable scientific information is made available to answer technical questions of premining planning.

386. Margolf, C.W., Public Information-Industrial Involvement, paper presented at American Mining Congress, 1976 Coal Show, Detroit (May 10-13, 1976).

In discussing Public Information and Industry's Involvement, the author does so in the context of the surface coal mining industry in the western United States. According to the author, public confidence in our institutions is essential and must be earned. Most companies provide information about what they are doing or attempting to do. This is important since the public is not unified with respect to the nation's problems. The author further emphasizes that "the purpose of providing the public with information should be to see that this nation has an informed public;" industry can help to do this, especially on the local level. This article is not technical and encourages a cooperative approach to mining and reclomation planning.

approach to mining and reclcotion planning.

Resource and Land Investigations Program: An Approach to Environmental Assessment with Application to Western Coal Development, MTR 6988, Mitre Corp., McLean, Va., prepared for Resource and Land Investigations Program, U.S. Geological Survey, Reston, Va. (Aug. 1975). 
The use of coal reserves in the western U.S. is seen as a possible means of achieving a measure of energy self sufficiency. In addition to strip mining, the development of western coal can include mine-mouth electricity generation or coal gasification as well as the shipment of energy via unit trains, slurry pipelines, or overhead transmission lines. This report describes an approach for evaluating the environmental impacts of various coal development projects. Each project is composed of a number of activities and the primary and secondary impacts: of these activities are linked together by means of a key-word cross referencing system. Therefore, it is quite technical in orientation, and requires a basic understanding of the engineering aspects of coal developments.

388. Saperstein, L.W., and E.S. Secor, Improved Reciamation Potential with the Block Method of Contour Stripping, (selected papers), Research and Applied Technology Symposium on Mined Land Reclamation, Pittsburgh, Penn., pp. 25-38 (1973).

389. Soil Conservation Service, Kentucky Guide for Classification, Use, and Vegetative Treatment of Surface Mine Spoil, U.S. Department of Agriculture, Lexington, Ky., 1971, 31 pages (rev. 1973).

The guide presents a system of spoil classification, based on acid/base balance and stoniness, with suggestions for land use after reclamation, and a comprehensive guide to plant species suitable for various spoil classes. Appendixes include a breakdown of use characteristics, vegetation characteristics; a sample reclamation plan, and a glossary of terms. The guide was developed for use by Soil Conservation Service personnel in fulfilling their role as advisors in strip mine spoil reclamation. It is technical in nature, and requires a knowledge of reclamation practices and agronomy.

Critical Areas, Resource and Land Investigation Program, Office of Land Use and Water Planning and U.S. Geological Survey, Department of the Interior, Reston, Va. (Jan. 1976).

At all levels of government, challenges have recently arisen over the protection of vital resources, provision of housing and employment, energy supply, and environmental quality. Regional analysis and land use planning are necessary to resolve these conflicts. Due to federal ownership of land and federal sponsorship of transportation, water resources, and sewage systems, and federal participation in countless other areas of American development, the federal government is playing a major role in determining land use. Also, comprehensive land use legislation is emerging on the state level. The decision-making and management processes of these programs usually involve resource inventories and data collection, public participation, policy formulation, and identification and designation of critical areas of proposed developments, if any. Experiences of Florida and Maine with their programs are examined. Guidelines on data acquisition and processing, available computer information systems, applications, and supporting documents are provided to aid the reader. This is a publication designed for regional planners. 
391. Wickersham, Kirk, R.P. Hansen, and A.G. Melcher, A Land Use Decision Methodology for Environmental Control, EPA-600/5-75-008, Socioeconomic Environmental Studies Series, Office of Research and Development, U.S. Environmental Protection Agency, Washington, D.C., 185 pages (March 1975).

This report to the Environmental Protection Agency (EPA) proposes an ecologically responsible land use decision-making system for local, regional, and state governments, referred to as LUDMS.

The fundamental premise of LUDMS is that environmentally responsible land use planning and control must be based on valid ecological information combined with enlightened and informed public opinion.

LDMS makes use of several concepts, including policy planning (a process for combining public opinion with scientific and technical information to create community policies); use of an interdisciplinary team; public participation; an environmental resources inventory and analysis; a staff that understands and can communicate about ecology; legal devices for land use control; and positive community programs.

Model state and local codes are provided, although the term example might be more appropriate, because of the diversity of requirements in various jurisdictions.

392. Wobber, F.J., and D. Garofolo, Remote Sensing for Mined Area Reclomation,

$X$ Applications Inventory, Bureau of Mines, U.S. Department of the Interior,

$X$ Washington, D.C., 40 pages (1971).

\subsection{REPRESENTATIVE ORDINANCES, PLANS, AND STUDIES}

393. Buck, R.J., L. Radner, M. Rifkin, and R.B. Shaller, Comprehensive Analysis and Action Alternatives for Northeastern Pennsy Zvania, Volume I: Executive Summary; Volume 2: The Cument Situation; Volume 3: The Development Future, Open-File Report No. 3-71, prepared by the Mitre Corp., Contract No. 50101245, for the Bureau of Mines, U.S. Department of the Interior, Washington, D.C., 816 pages (Oct. 1970).

This extensive report is a comprehensive regional development and planning study of the entire Northeastern Pennsylvania area, encompassing most of the anthracite coalfields and the northeastern outliers of the bituminous coalfields. Detailed study is made of surface coal mining in the region, with analyses of its social, economic, and environmental effects. Strategies are outlined for combatting the existing adverse effects that include reclamation of orphaned land and the prevention of further degradation. Specific provisions are set forth for the control. of future surface mining. of particular concern are mine fires, land subsidence as a result of underground mining, refuse banks, and surface mine spoils where these are in proximity to urban areas. The main thrust of the devlopment plan is the improvement of economic, social, and environmental conditions in the area. The report is highly detailed and quite technical. However, it is designed for use by planners, and, as such, is oriented toward their needs. 
394. Candeub, Cabot, and Associates, Surface Land Reclamation Plan for the

$\checkmark$ Borough of Tayzor, Pennsyzvania, Scranton, Penn., 38 pages (1966).

39.5. Clark, D., State of the Art: Uranizm Mining, Milling, and Refining Industry, Robert S. Kerr, Environmental Research Laboratory, Project Number 21 AGF-02, prepared for Office of Research and Development, U.S. EPA, Corvallis, Ore. (June 1974).

This report presents an overview of the uranium mining, milling, and refining industry of the United States. Topics discussed include ore reserves, geographic locations, production statisitcs, future requirements, effects of waste on the environment, standards for radiological protection, testing and monitoring programs, technological advances within the uranium industry, anticipated future problems and recommended areas for further study.

This report is very technical in nature and is intended for professionals in the engineering or mining field.

396. Fisser, H.G., and R.E. Ries, Predisturbance Ecological Studies Improve and Define Potential for Surface Mine Reclamation, Third Symposium on Surface Mining and Reclamation, Louisville; Ky., I:128-134 (Oct. 2123, 1975). $X^{397 .}$ Natural Resource Zone Ordinance, Maryland National Capital Park and
Planning Commission, Silver Spring, Md., 13 pages mimeo (1966).

This is a model ordinance designed to designate areas as natural resource zones for extractive land use and rehabilitation to other land uses as resources are removed. Provision is made for pre-existing uses. Criteria for the performance and development of extractive activities are clearly set forth with detailed standards for the control of blasting vibrations and other offsite effects. Site and rehabilitation plans are required before permission is granted for the commencement of operations. Reclamation requirement for a performance bond or cash deposit to cover the cost of reclamation in the event of noncompliance. Permit procedures and information requirements are included. The model ordinance is clear, easily understood, and adaptable to a variety of Zocales.

398. Preston, J., E. Strauss, T.0. Friz; Model Mineral Reservation and Mining Ordinance, Circ. No. 24, Geological and Natural History Survey, University of Wisconsin, Madison (Nov. 1974).

This model ordinance is designed to protect mineral resouxces from urban growth and to insure their orderiy development and reclamation. Its intended purpose is to guide Wisconsin counties in establishing mining laws that function under existing zoning clauses. Some provisions covered are permitting, reporting, and bonding; changes of ownership permit renewal; and others. Under this ordinance, mining activity is regulated to prevent nuisance situations and to protect public health. Penalties are suggested for violations. Although modeled to comply with Wisconsin legal structures, the proposed methodology of enactment and the comprehensive coverage of mining problems should have wide-spread application. 
X39.

Quarry Stcondards, Planning Commission Resolution.No. 6178, Adopted Aug. 16, 1961, by the County of Santa Clara, Calif.

As an example of standards and regulations that may be developed and utilized by local authorities, these are detailed ani. specific. Standards for the excavation of materials for sale are desıgned to control the appearance of operations and the offsite effects of quarrying and sand and gravel operations. Specific standards relate to screening, noise and dust control, drainage, setbacks, public safety, plant location and operation, operating hours, site access and maintenance. Rehabilitation is directed in terms of future land use and considers operating standards for grading and backfilling, drainage and erosion control, and the removal of structures and equipment.

$\chi_{400}$

Reclamation Plan, Indian Boundary Quarry, Will County, IlZinois, prepared for Meyer Material Company, Des Plaines, Illinois, by Associated Planners, Highland Park, I1l., 9 pages, maps and appendix (Aug. 1973).

This document comprises three plans: (a) conservation plan; (b) operations plan; and (c) reclamation plan. In the words of a partner at Associated Planners; "This is the only reclamation plan I have seen which starts out with stated conservation objectives and a plan for preservation, then identifies how operations will commence, and finally, presents the reclamation plan with final contours," (letter of transmittal to American Society of Planning Officials, May 21, 1975). The document is nontechnicat but requires a basic understanding of natural resources conservation. It is an excellent example of a plan developed to meet the requirements of county regulation of surface mining and quarrying.

401. Stewart, E.E., and R.E. Stewart, A Multiple Land Use Study for a NineCounty Area of Southwestern North Dakota, Little Missouri Grassland Study, North Dakota State University, Fargo, 300 pages plus maps (1974).

Use Permit Conditions for Commercial Excavating, Crushing, and Washing, Planning Department, County of Santa Clara, Santa Clara, Calif., 3 pages mimeo (1961).

The above is a brief document setting forth specific requirements for an unnamed operation along Coyote Creek, Santa Clara County. Although the document relates to a particular commercial quarry, it is illustrative of a county agency's efforts to regulate surface mining within its jurisdictional boundaries. There are provisions for site screening and dust control, with consideration for noise control and site rehabilitation. Provisions are clearly set forth and their intent well stated.

\subsection{PERFORMANCE CONTROLS}

403. Ahearn, V.P., The Zoning Problem and Its Significance to the Sand yand Gravel Producer, Committee on Public Relations, National Sand and U Grave1 Assoclation, Silver Spring, Md. (1960). 
With industry opposition of zoning becoming ineffective, sand and gravel operators are urged to participate in formulation of new zoning laws within a community. Advantages to the community must be pointed out. For instance, a sand and gravel site within the community would lower customer costs for this material, since most of that cost is for haulage. Additional points discussed at length are the limitations of local zoning board authority and the basic provistons of local zoning laws.

404. Callies, D.L., and J.R. Quay, Zoning for Gravel Pits: Simultaneous Rehabilitation According to Plan, Land Use Controls Quarterly (n.d.).

Facts that shape the sand and gravel industry are as follows: Deposit locations and subsequent mining often conflict with original and adjacent land uses. Extraction and processing destroys original land capabilities. Zoning out the industry requires the import of raw material for construction in the area and raises the cost of finished products. Most jurisdictions regard the mining of sand and gravel as a property right that can be regulated but not prohibited. In 1968, the McHenry County Planning Commission, the Unfverstiy of Illinots, and a large mine operator cooperated to produce a set of ordinances. As published in the article, they cover (1) operating procedures, (2) rehabilitation sequences, (3) recommended ultimate zoning classifications, (4) site layout plan, and (5) site grading plan.

405. Henkes, W.C., Satellite Monitoxing of Open Pit Mining Operations, Dif Bureau of Mines Information Circ. No. 8530, U.S. Department of the Interior, Bureau of Mines (1971).

406. Hickerson, H.C., Utilization of Photogrammetry and Moderm Computer Ol Techniques to Calculate Monthly Production Quantities for Strip Mines, Third Symposium on Surface Mining and Reclamation, Louisville, Ky., I: 200-208 (Oct. 21-23, 1975).

Х 407.

Jones, J.R., and J.L. Beckner, Federal and State Permitting Requirements, Second Research and Applied Technology Symposium on Mined Land Reclamation, Louisville, Ky., pp. 24-28 (Oct. 1974).

This is a detailed account of the effort of Peabody Coal Company to meet the requirements of recently enacted legislation. The mine in question was the Big Sky Mine in Montana, which was in operation before the onset of new, stricter state laws and the National Environmental Policy Act. With. the resulting changes in permit requirements, time spans from mine conception to coal delivery have lengthened considerably due to requirements for environmental impact statements and public hearings. Survey costs are rising proportionate to the number of new regulations, and probably would be damaging if permits were not eventually granted. Complications were encountered due to the fact that existing mines under contractual obligations were close to stoppage in their attempts to meet the tangle of new state and federal regulations. Actual confusion between the wording of the law and translated regulations by mine operators and enforcement officials existed. Close cooperation was necessary to expedite matters. The paper provides insight into the legal maneuvers and contacts often necessamj in planning a mine operation. 
P.X

408. McCulloch, C.M., Applying Computer-Drawn. Maps of Geologic Data to Analysis of Mining Problems, Bureau of Mines Report of Investigations No. 8151 , U.S. Department of the Interior, Pittsburgh Mining and Safety Research Center (1976).

409. Salmen, L.J., D.J.Matter, and E.J. Hoffman, A Two-Phased Strip Mining Pilot Study: I - The Effect of Legislative Slope Restrictions of Strip Mining Operations; II - Determination of the Critical Factors Affecting

(X Reciomation Success and Costs, Federation of Rocky Mountain States, Denver, Colo., 15 pages, figures, appendix (1973).

$\mathrm{P}^{\mathrm{Q} 410 .}$

Schaffer, R.B., The National Pollutant Discharge Elimination System and The Coal Industry, Third Symposium on Surface Mining and Reclamation, Louisville, Ky., I:206 (Oct. 21-23, 1975).

The National Pollutant Discharge Elimination System (NPDES) is outlined and discussed in terms of the type of standards required, and the provisions of permits for surface mine effluent discharges. The provisions of the associated compliance schedule and self-monitoring requirements are reviewed, as are bypass conditions. Discharge permits for surface mine effluents are considered to include active mining and reclamation to the point of grade bond release by the state. The paper is clearly written and easily read, and is designed for informational purposes.

X 411. Schreibeis, W.J., H.H. Schrenk, Evaluation of Dust and Noise Conditions at Typical Sand and Gravel Plants, Committee on Public Relations, National Sand and Gravel Association, Silver Spring, Md. (n.d.).

This highly technical report documents sound level and dustfall measurements taken at seven sand and gravel plants. Descriptions of each site and the associated monitoring stations are given, augmented with aerial photographs. Data on background and plant noise levels are graphed in decibels versus cycles per second. Plant noise adds approximately $20 \mathrm{db}$ to background measurements. Dustfall is tabulated monthly and separated into soluble and incombustible, with figures ranging to about 50 tons/acre-mo. This work is intended for engineers.

412. Tryzal. T.C., Environmental Impact Requirements in the States, Socioeconomic Studies Series, Environmental Protection Agency, R5-73-024, Washington, D.C., 20 pages (June 1973).

The requirements of environmental impact analyses for each of the various states has been surveyed. In eight states and in Puerto Rico, impact statements are a statutory requirement; in four states, they are required by Executive order. In a few cases, the impact statement requirement extends to local as well as state agencies.

Normally, states having EIS requirements do not extend them to private activities. Exceptions are Wisconsin, Montana, North Carolina, California, and Puerto Rico, where EISs are required, or authorized to be required, as a part of permit procedures. Implementation is uneven. A table, Requirements and Proposals for Environmental Impact Statements in the States, is presented as an appendix. The work is 
essential reading where environmental impact statements may be..regarded as a planning tool for data acquisition and the evaluation of reclamation proposals. It is oriented toward planners, nonengineering professionals and interested citizens.

413. Wohler, W:A., Coal Refuse Regulations, Standards, Criteria, and Guide$\checkmark$ Zines, paper presented before First sympostum on Mine and Preparation V Plant Refuse Disposal, Loulsville, Ky., pp. 78-85 (1974).

\section{6:5 ENVIRONMENTAL AND SOCIAL IMPACTS}

414. Callahan, J:C., and J.G. Callahan, Effects of Strip Mining and Technological Changes on Commonities and Natural Resources in Indiana's (Coal Mining Region, Research Bulletin No." 871. Agricultural Experiment Station, Purdue University, Lafayette, Ind., 43 pages (1971).

Coal is plentiful in southwestern Indiana, providing low cost electricity for the regton. Long distance transmission of power, facilitated by the proximity of coal and the increasing mechanization at mines has aggravated the local employment-development gap. in the sample counties studied. Emigration of young adults has increased the average age of the population. Concern over the amorphous quality of aesthetics as a guide in reclaiming mined land is expressed. It is also feared that imposition of costly reclamation procedures will reduce economically minable reserves, which are expected to last only until the year 2000. Postmining and reclamation land uses for forestry and recreation were studied. The progressive land management policies of coal-mining firms are highlighted. This report is informative, well illustrated and seadable.

415. Charmbury, H.B., Coal and the Environment, Coal Mining and Processing, II :69-70 (Jan: 1975).

This paper relates the coal industry with environmental awareness. Steps taken to minimize the negative effect of coal mining on the environment are discussed in regard to water and air pollution, and land reclamation. This article is written on a nontechnical level; it is oriented toward the general public.
}

DU 4 416. Council on Environmental Quality, Coal Surface Mining and Reclamation: An Environmental and Economic Assessment of Alternatives, prepared for the Committee on Interior and Insular Affairs, U.S. Senate, 93rd Congress, Serial No. 93-8 (12-13), U.S. Government Printing Office, Washington; D.C., 145 pages (March 1973).

This document discusses surface mining and reclamation techniques in regard to various kinds of contour mining, auger mining, and longwall surface mining. Impacts on the environment from these vartous mining techniques are analyzed. The author concludes this document with discussions on state regulatory programs and the effects of slope angles on mining. 
417. French, R:R., A.W. Stuart, and D.H. White, Socioeconomic Aspects of Mining in Selected Cities Urbanization and Surface Mining in Atlanta, Georgia, Information Circ. 8477, Bureau of Mines, U:S. Department of the Interior, Washington, D.C., 50 pages (1970).

The industrial minerals industry in the Atlanta, Georgia, area was studied in order to better understand the problems associated with exploiting mineral resources in and near metropolitan areas. A method for delineating the Atlanta urban area and its component parts was developed so that factors affecting the location of minerals industries could be viewed more objectively in the urban context. Major attention is focused on the area's dominant. crushed stone subindustry.

Deomgraphic and socioeconomic analysis of the Atlanta, Georgia, area shows that expansion of the metropolis and its environs will probably eliminate potential mineral resources from the mineral resource base in the area and that the expanding metropolis will be the primary determinant of future mining sites. Competition for land is accentuated to varying degrees by the incompatibility of mining operations with residential and other environmental requirements.

Areas of consideration are suggested to provide maximum development of land and resources for greatest economic benefits at minimum social cost. Further research is recommended to determine market locations in urban areas, optimum operating levels for industrial mineral plants, and alternatives to surface mining.

The report is intended for urban, regional, and environmental planners.

418. McKelvey, V.E., Environmental Objectives in Regulating Surface Coal X Mining on Federal Lands, Third Symposium on Surface Mining and Recla$\checkmark$ mation, Louisville, Ky., I:7-8 (Oct. 21-23, 1975).

419. Montgomery, H.B., Environmental Analysis in Local Development Planning, Geologic Mapping for Environmental Purposes, H.R. Ferguson (ed.), Geological Society of America, Engineering Geology Case Histories, No. 10. (June 1973).

In this paper, the author argues the importance of environV mental analysis for beneficial economic and social development. Physical aspects of the environment (air, water, land, etc.), which are biologically, socially, and economically important to man, should be given proper consideration in the planning process. Two tables have been constructed that categorize economic and social development. The developmental categories can be cross-referenced to maps needed and types of maps used in planning. A few addresses are given whereby one might obtain needed maps or other information; other agencies are listed through which a planning agency might obtain data needed for environmental planning.

The publication will be of interest to land use or environmental planners. 
420. Nolden, C., Environmental Consultants: Obtain a Niche in Coal, Coal Age, Vo1. 13 (June 197.6).

"There's no question that coal mining is disruptive to the ecological system of an area. The question is how detrimental is the disturbance and what can be done to mitigate the damage certain to occur?"

This article discusses the role of environmental consultants in regard to protecting the environment. This protection is provided through environmental impact statements (EIS) which assess just how mining operations may affect the water quality, vegetation, and wildlife of an area.

This paper is primarily nontechnical reportage for a wide and varied audience.

421. Osterhoudt, F.H., Social and Economic Impacts of Potential Coal Development in the Northern Great Plains, paper presented before Second Research and Applied Technology Symposium on Mined-Land Reclamation, Louisville, $\mathrm{Ky}$., pp. 76-87. (Oct. 1974).

An analysis of the possible effects of Project Independence on the Northern Great Plains, this work studies the regional impact that a boom in the coal and power industries would have. With enough coal in the area to last 400 years, development scenarios of varying intensity and their effects on the local population are projected into 1985. The coal and power industries, under great demand, are likely to completely displace agriculture and to urbanize the region. In meeting manpower requirements, large numbers of people must be settled in rural areas in short time periods. Statistics on earnings, employment activities, and tax bases are projected.

422. Ray, J., Strip Mining in Ohio: A Comparison of Measured Human Attitudes and Stated Opinions, Extraction of Minerals and Energy: Today's Dilemma's, Raul A. Deju (ed.), Ann Arbor Science Publishers, Inc., Ann Arbor, Mich. (n.d.).

This study investigates the nature of that portion of the social milieu reflected in human attitudes and stated opinions of a sample population in Ohio toward the concept of strip mining for coal. Data is collected with a questionnaire and an attitude scale is constructed for the project, using Thruston's method of paired comparison. The study area included 11 counties selected to produce a spatial bias in the data.

This study is oriented toward the sociologist, but can be comprehended by the planner with a knowledge of survey data collection and interpretive processes.

423. Specht, R.C., Effect of Waste Disposal of the Pebble Phosphate Rock Industry in Florida on Condition of Receiving Streams, Transactions of the Aime, 187:779-784 (1950). 
424. Weinreich, G., and R. Fagan, Consultants, Socioeconomic Significance. of Western Surface Coal Mining, presented at the Society of Mining Duf Engineers Fal1 Meeting, Salt Lake City, Utah (Sept. 10-12, 197.5). 
THIS PAGE WAS INTENTIONALLY LEFT BLANK 
AUTHOR INDEX .

Abell, L.F., 29

Ackerman, D.H., 316

Ackerman, W.C., 320

Agria, S.R., 84

Ahearn, V.P., 403

Ahmad, M., 279

Akers, D.J., 228

Akin, G.W., 184

Aldon, E.F., 238

A1len, N., Jr., 119

Allen, O.R., 234

Almes, R.G., 379

Anderson, C., 352

Anderson, R., 322

Anderson, R.J., 124

Arizona University of, Colleges of Architecture and Mines, 315

Armiger, W.H., 220

Armstrong, E.H., 320

Associated Planners, 400

Aughenbaugh, N.B., 317

Baker, D., 281

Barnhisel, R. I., 184

Barroẅs, H:L., 298.

Barry, T., and Associates, 1.21
Bauer, A.M., 362, 376

Baumann, A.N., 280

Baxter, J.G., 377

Beck, R.E. , 32

Becker, B.C., 225

Becker, J., 206

Beckner, J.L., 407

Bennett, 0.L, 220

Berg, W. , 239

Bhappu, R., 281

Bịshko, D., 318

Bitler, J.R., 85, 86

Bituminous Coal Research Inc., $2,22,30$

B1akely, J.W., 33, 122, 185, 1.86; 187

Blazer, J.L., 297

Blizzard, S.H., 240

Boeh1je, M., 108

Bond, J.J., 209, 266

Bosse1man, F.P., 34

Bowden, C., 3

Bowden, K.L., 4

Boyce, S.G., 241

Boyce, T.A., 87

Boyle, J.R.; 88 
Brealey, S.C., 123

Breeding, C.H.J., 242

Brenner, F.J., 226

Breslin, J.J., 124

Brinkman, K.A., 268

Brittain, K., 155

Brock, S.M., 89

Brooks, D.B., 5, 89, 90

Brown, C.B:, 302

Brown, E.H., 236, 287

Brown, J.H., 243

Bryant, H.L., 95

Bucholz, J., 305, 306

Buck, R.J., 393

Bunch, J.P., 204

Bureau of Land Management, 310

Bureau of Mines, 93, 212

Bureau of Outdoor Recreation, 359,367

Burner, C.C., 319

Bush, J.M., 91

Buturla, F.J., 125

Byrnes, W.R., 254, 255

Cairns; J., Jr., 334

Caldwe11, N.B., 6

Calhoun, D., 320

Callahan, J.G., 414
Callahan, J.C., 414

Callies, D.L., 404

Camin, L.Q., 299

Campbe11, R.A., 126

Candeub, C., and Associates, 394

Capp, J.P., 244, 245

Car1in, D.F., 97

Carlson, C.G., 300

Carpenter, L.H., 7

Carter, R.P., 188, 321

Casali, J.T., 282

Cason, B.P., 372

Caspa11, F.C., 227

Cassidy, S.M. (ed.), 127

Charmbury, H.B., 415

Chironis, N.P., 128

Christiansen, C.R., 317

Clark, D., 395

Clouston, J.B., 322 .

Coal Age, 129, 130, 139, 159, $165,172,359$

Coaldrake, J.E., 8

Coalgate, J.L., 228

Coates, J.A., 109

Coates; W.E., 323

Congressional Digest, The, 36.

Conne11; J.P.; 131, 283 
Conry, T.J., 38.

Contractor, D.N., 283

Cook, F.X., Jr :, 229

Copeland, O.L., 324

Cornforth, C.L., 132, 133, 134, 135, 325

Council of State Governments, 114, 383, 449

Council, on Environmental Quality, 92, 416

Cox, J.L., 284

Croke, E.J., 321

Crouch, D., 297

Crow1, J.M., 210

Curry, R.B., 15

Custred, V.k., 136

Dale, M.E., 246

Dalstead, N.L., 9

Davenport, J.E., 286, 287

Davis, G., 199

Davis, R.W., 288

Dean, K.C., 289

Deane, J.A., 230

Deely, D.J., 378

DeMoss, E.C., 94

Denuyl, D., 247

DeTuerk, J.R., 349

Dick, J.H., 191
Donner, D.L., 192

Dreese, G.R., 95

Dressler, R.L., 273

Dunn, J.R., 318

Dusek, G.L., 301

Dwyeré, D.D., 13

Earney, F.C.F., 10

Elder, J.L., 137

E11ison, R.D., 379

Engineering and Mining Journal, 350

Environmental Protection Agency, $1,277,285$

Evans, R.J., . 85, 86

Everett, H.W., 198, 336

Fagan, R., 424

Falkie, T.V., 138, 177

Farrand, E.P., 202

Ferko, 'M.R., 163, 170

Finn, R.F., 248

Fisser, H.G., 249, 396

Foreman, J.W., 97

Foreman, W.E., 98

Forrester, J.D., 140

Foster, C.A.; 198, 336

Fowkes, W.W., 250

Fowler, D.K., 327

Fox, R.E., 37 . 
Frawley, M.L., 11

Freeman, P.G., 250

French, R.R., 417

Fritsch, A.J., 38

Friz, T.0., 328, 339, 398

From, R.W., 228

Fuller, J.A., 141

Funk, D.T., 12, 251

Gaffney, M. , 99

Gantner, G.K., 299

Garofolo, D., 216, 392

Gatherum, G.E., 257

Geological Survey, U.S., 390, 457

Gifford, G.F., 13

Gillespie, M., 100

Gillmore, D.W., 244, 245

Giorgetti, L., 354

Glover, H.G.; 329

Goldberg, E.G., 39, 40

Goodland, N.L., 252

Goodman; L.E., 302

Goodwin, F.W., 331

Gould, W.L., 230

Grandt, A.F., 253

Green," J.E., 14

Green, J.W., 142

Greenbaum, M.E., 101
Greenwald, E.H., 331

Griffith, F.E., 217

Grim, E.C., 193, 332

Groenwald, G.H., 352

Grube, W.E., Jr., 194, 218

Gschwind, J., 278

Gulf 011 Corp., 143

Gunnett, J.W., 333

Hadley, R.F., 195

Hagen, H.D., 144

Haley, M.J., 102

Haley, W.A., 145

Hall, R.E., 41

Hamilton, L.W., Jr., 196

Hanchey, J.R., 380

Hansen, R.P., 39.1

Hart, G., 254, 255

Hartman, .H.L., 146

Harvey, C.E., 101

Hasslacher, R.N., $11 \dot{5}$

Havens, R., 289

Hedrick, H.G., 304

Heine, W.N., 147

Hemish, L., 352

Hench, L.L., 373

Henke1, D.J., 158 
Henkes, W.C., 405

Herfindah1, 0.C., 103

Herricks, E.E., 334

Hickerson, H.C., 406

Higgins, T., 335

Hil1, R.D., 193, 290, 332

Hines, B.J., 197, 336

Hodder, R.L., 305, 306

Hoffman, E.J., 70, 409

Hoffman, G.J., 15

Hole, W.E., Jr., 337

Holland, C.T., 104

Holmberg, G., 338

Ho? sten, R.M., 42

Honkala, R.A., 16.

Hopper, W.H., 148

Hortenstine, C.C., 276

Horton, J.0., 43

Horvath, W., 338

House Committee on Interior and Insular Affairs, $35,45,60,61,63,64,65$, $70,71,80,81,92$

Howard, H.A., 44

Howland, J.W., 219

Hrovatic, C., 198

Hutnik, R.J., 199

Imhoff, E.A., 339
Indiana, Department of Natural Resources, 189

Investor Responsibility Research Center, Inc., 175

Jackson, D., Jr., 149

Jasper, D. , 150

Jensen; D.R., 381

Johnson, C., 151, 382

Johnson, J.E., 32

Jones;, J.N. , 220

Jones, J.R. , 407

Jones, W.G., 200

Kachanowsky, B.J., 152

Kealy, C.D., 291

Keffler, C.A., 347

Kennedy, A.S., 188, 321

Kieffer, F.V., 17

Kief fer, G.W., 286, 287

Kimba11, R.L., 217

Kirkpatrick, J.C. , 234

K1.ing, C.L., 203

Knight, H.E., 153

Koehler, D.A., 203

Krause, R.R., 292, 340, 341

Kruse, E., 192

Krutzfeldt, w., 41

Kube,.. W. , 137 
Kune, B.R., 46

Laird, W.M., 300

LaFevers, J.R., 105, 154, 321, 338, 339,344

Lang, A.L., 253

Lanim, A.E., 384

Lantz, E., 47

Larkin, R.P., 342

Laszkiewicz, O.T.M., 18

Leistritz, F.L., 9

Leonard, M.R., 343

Limstrom, G.A., 19, 256

Lockner, A.0., 106

Loofburrow, R.L., 155

Loomis, T.H.W., 20

Lorio, P.L., 257

Love11, H.L., 356

Lowry, G.L., 258, 259, 260

Mackleston, S., 49

MacLouchlan, R.S., 261

Magnuson, M.0., 217

Ma1colm, E., 217

Ma1in, H.M., Jr., 50

Maneva1, D., 345, 346

Manning, H.C., 51

Manula, C.B., 177
Margolf, C.W., 386

Markey, T.R., 52

Martinka, P.D., 347

Maryland National Capital Park and Planning Commission, 397

Mason, G.J., 53

Master, D.L., 54, 70

Mathematica, Inc., 156

Matter, D.J., 409

May, R.F., 221

McCann, S., 301

McConnen, R.J., 117

McCormack, D., 232

McCulloch, C.M. 408

McCutcheon, K.C., 55

McFadden, D., 157

McKay, M., 8

McKelvey, V.E., 418

McNay, L.M. , 229

Medvick, C., 201, 262

Meigh, A.C., 158

Melcher, A.G., 391

Meshenberg, M.J., 21, 348

Millford, R.H., 202

Miller, E.L., 349

Mills, T.R., 225

Mining Congress Journa1, 176 
Mitre Corporation, 387

Miyamoto, S., 231

Moher, J.E., 205

Monk, R., 24

Montgomery, H.B., 351, 419

Moomaw, J.C., 331

Moore, R.T., 203

Moran, S., 352

Morgan, M.L., 38

Morning, J.L., 354

Morris, G., 293

Moudgill, B.M., 204

Munn, R.F., 23

National Academy of Sciences, 309

National Coal Association, 79

Nawrocki, M.A., 294

Neebe, D.J., 241

Nephew, E.A., 97, 107

Newport, B.D., 205

Nielson, R.F., 263

Nolden, C., 160, 420

Norton, B.E., 13

Office of Land Use and Water Planning, U.S., 390

Osterhoudt, F.H., 421

Otte, J.A., 108
Overton, R., 116

Packer, P.E., 306, 324

Paller, W., 353

Pàone, J., 354

Perry, C.H., 327

Pennington, D., 307

Pennsylvania, Research Committee on Coal Mine Spoil Revegetation, 375

Pennsylvania State University Mining Pollution Control Branch, Department of Minera1. Engineering, 385

Persse, T.H., 355

Peters, G.L., 342

Peters, J.W., 356

Peterson, H.B., 24, 263

Peterson, J.R., 278

Pfleider, E.P., 161

Phillips, G., 162

Pickels, G., 357

Plass, W.T., 264, 265, 283

Powe11, J.L., 184

Power, G., , 39

Power, J.F., 209, 266

Power, T.M., 58

Poyser, R., 297

Preate, E.D., Jr., 59

Preston, J. , 398 
Public Land Law Review Commission, 57

Pudiey, T., 206

Pundari, N.B., 109

Pyles, H.K., 62

Quay, J.R., 404

Radner, L., 393

Rai, D., 231

Ramani, R.V., 163, 170

Ratchye, J.F., 164

Ray, J., 422

Reed, L.A., 233

Rei11y, J.D., 360

Reitze, A.W., Jr., 66, 67, 68

Renkdy, L.E., 69

Ries, R.E., 249, 396

Rifkin,. M., 393

Riley, C.v., 222, 267, 295, 361

Ringe, A.C., 25

Rinier, J.A., 295

Roberts, K.C., 365

Robertson, D.R., 203

Robinson, N., 110

Roe, P.A., 8

Roger, D.A., 363

Rothweli, D.F., 276

Ruble, R.W., 202
Ruby, G.R., 141

Rumflet, H. , 166

Russe11, 0.B., 378

Ryerson, D.E., 305, 306

Salmen, L.J., 70, 409

Sandova1, F.M., 209, 266

Santa Clara, County of, 399, 402

Sapèstein, L.W., 167, 388

Sawyer, L.E., 210

Schaffer, R.B., 410

Schellie, K.L., 362, 363, 364

Schneider, D.A., 72

Scholenberger, A., 71

Schretbeis, W.J., 411

Schrenk, H.H., 411

Schultz, D.A., 353

Schwab, G.0., 15

Scott, J.J., 317

Scott, M.D., 311

Secor, E.S., 167, 388

Seide1, K.W., 268

Seith, R.T., 234

Selner,'J.E., 168, 312

Senate Committee on Interior and Insular Affairs, 35, 45, 60, 61, $65,80,81,92$

Shackletion, R.D., 365 
Shaffer, S.L., 240

Shaller, R.B., 393

Shanholtz, V.o., 283, 334

Shields, D.H., 211

Sieh1, G.H., 26, 27, 45, 73, 74, 75

Simpson, D., 245

Sindelar, B.W., 305, 306

Singh, R.N., 194

Skelly \& Loy, Engineers-Consultants, 111

Smith, M., 296

Smith, R.M., 194, 218

Smith, V., 112

Sobek, A.A., 194

Soderberg, R.L., 291

Soil Conservation Service, 190, 389

Soler, D., 169

Sorre11, S.T., 198

South Dakota, State Legislative

Research Council, 76

Southeastern Illinois Regional Planning and Development Commission, 369

Sowards, W., 273, 297

Specht, R.C., 423

Spicer, T.S., 342, 356

Spore, R.L., 97, 107, 113, 367

Stachura, J.A., Sr., 171

Stamm, G.G., 368
Stefanko, R., 163, 1.70

Stewart, C.L., 77

Stewart, E.E., 401

Stewart, G., 314

Stewart, R.E., Jr., 78, 401

Strauss, E., 398.

Struthers, P.H., 269, 270

Stuart, A.W., 417

Su, Y.L., 177

Sutton, P., 271

Sweeney, J.W., 115

Tandy, C.R.V., 370

Tennessee Valley Authority, 120

Thirgood, J.V., 191, 371

Thompson, L.S., 117

Thrush, P.W., et a1., 31

Thurmond, R.E., 178

Tillotson,. I.M., 83

Timberlake, R.C., 223

Tintsman; R.A., 125

Tixier, J.S., 272

Tobler, R.H., 213

Tompkins, D.C. , 28

Treacy, J., 116

Tryzal, T.C., 412

Tyron, E.H., 243 


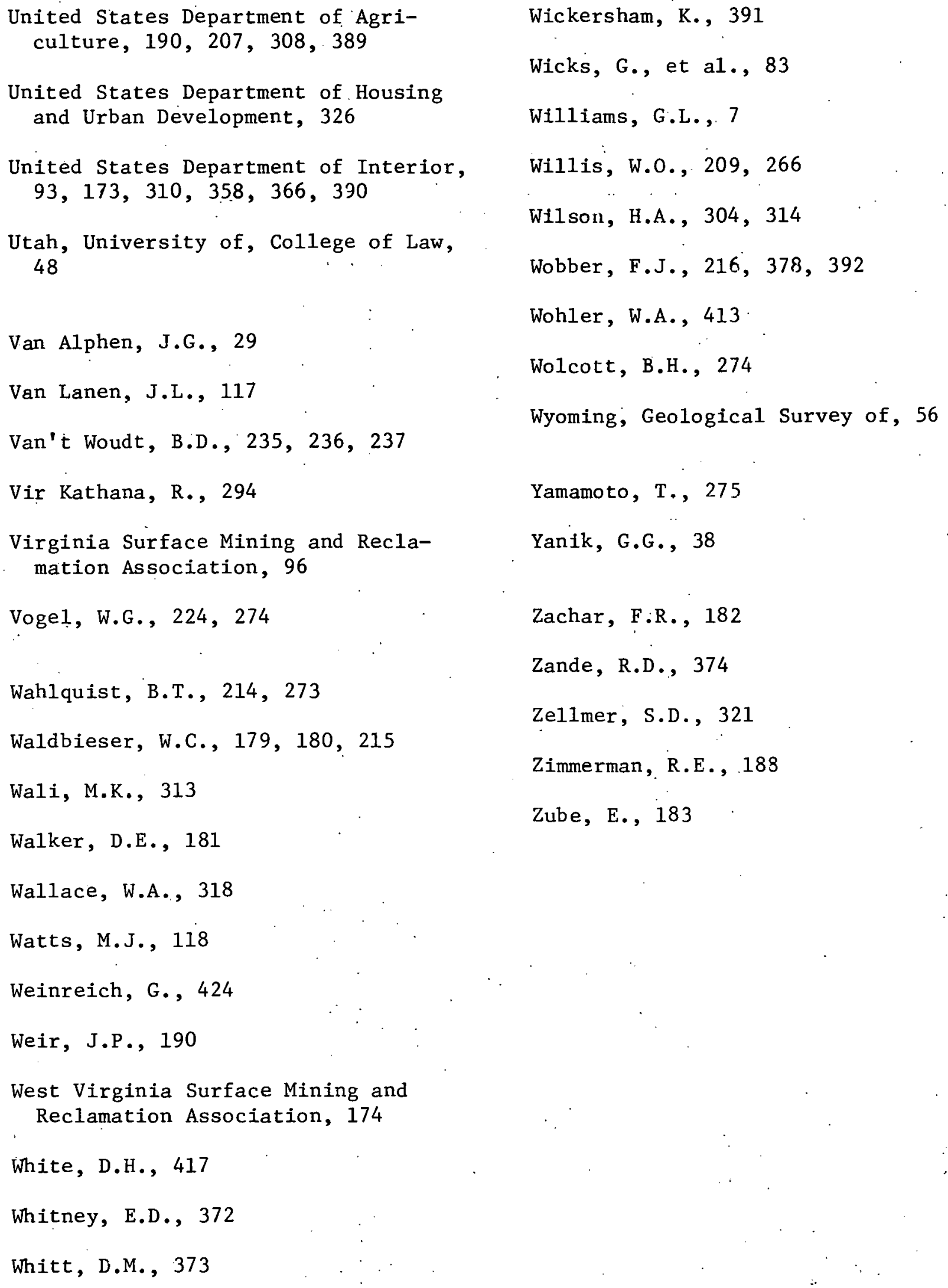




\section{SUBJECT INDEX}

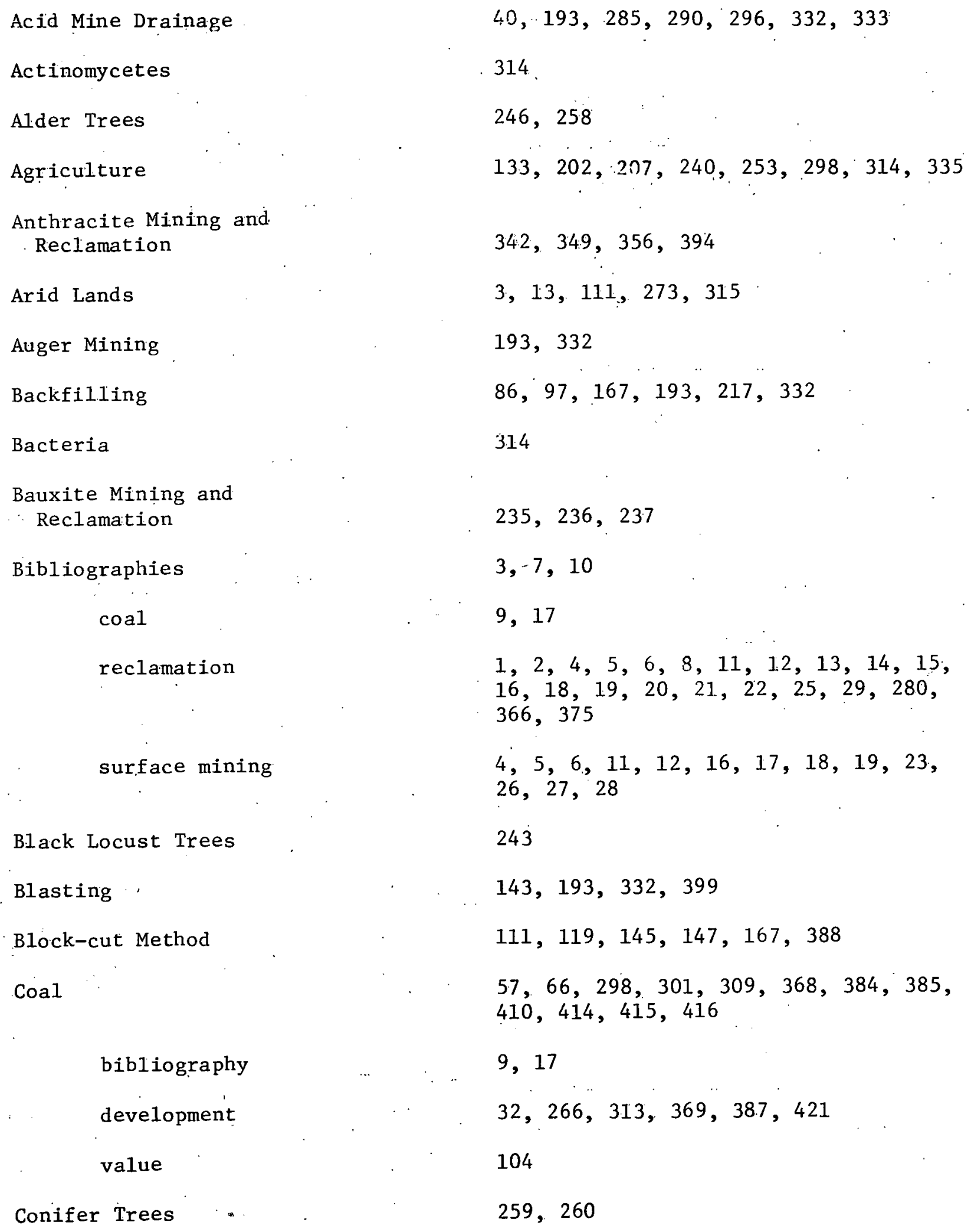


Contour Surface Mining

Copper

Costs

equipment

reclamation

surface mining

waste disposal

Costs/Benefits

Dams

Dewatering

Dictionaries and Directories

Drainage

Ecology

Economic Analysis

Economic Impacts

Economics

coal leasing

equipment

mining

reclamation

taxation

Energy

Environmental Impact

Environmental Protection
$86,92,119,145,167,173,175$

146,315

219

$70, .85,86,90,92,97, . .107,108,110$, $111,118,119,145,173,188,193,217$, $318,332,409$

$89,93,95,101,121,167,170,217$, 334,335

88

$89,101,105,313$

$211,291,332$

$138,155,212$

30,31

$22,196,290,292,295,332,334,400$

$199,249,267,361,396$

$5,87,90,97,108,111,121$

$92,417,421,422$

$89,103,105,112$

102

219

$94,113,114,121,416$

$97,105,120,124,313,335,393$

106

$80,96,324,387$

$92,285,334,335,355,387,393,411$, 412

$39,40,311,332,336,355,387,416$, 418,419 
Erosion Control

;

European Practices

Fertilizers

Fishery Management.

Fly Ash

Forestation

Furrow Grading

Geology

Grading

Groundwater

Haulage Roads

Haulback

Head-of-Hollow-Fi11

Indian Lands

Industrial Materials

Iron Ore

Kaolin Mining and Reclamation

Landfills

Landscape Architecture

Land Survey

Land Use

impact of mining

1imitations

mineral commodities

reclaimed 1 and
$97,190,194,197,225,226,235,236$, $237,240,263,273,305,306,332,336$, 359,400

$123,124,295,322,329,370$

$7,115,263,271,298,304$

319

244,298

see Vegetation

26

$318,326,343,352,-364,385$

$196,202,221,222,332,335,399$

123

$142,193,332$

$145 ; 196$

see Valley Fill Method

123

$146,362,364$

146

169

343

$323,349,352$

82

$189,324,381,383,401,403,404$

$266,363,373,377,404$

195,317

354

$120,174,204,267,328,354,363,374$, 390 
Leasing Aspects Legal Aspects - laws, legislation,
regulations

environmental problems federal

laws

state

Legislation

Lignite Mining and Reclamation

Metal Toxicity

Mine Management

Mineral Deeds

Mineral Industries

Mineral Resources

Minera1 Rights

Mineral Terms

Mining

equipment

methods and techniques

systems

Natural Resources

Open-Cut Mining
$32,41,44,46,52,53,68,71,102$

$33,37,38,39,42,43,45,48,51$, $53,54,60,66,68,69,73,77,78$, $79,81,82,90,101,154,175,313$, $321,338,344,386,399,402,413$

$39,40,47,55,59,62,120,145$

$34,35,36,37,43,45,50,54,57$, $58,61,63,64,65,73,74,75,80$, $81,385,407,410$

$67,79,83,124,339,397$

$32,38,41,49,56,71,76,79,202$, $339,375,383,398,407,412$

see Legal Aspects

$137,209,300$

24

$91,106,121,146,350$

$32,46,52$

18,84

$310,320,328,330,398,417$

$32,44,51,53,78,104$

31

$298,310,328,332,354,372,373$, 378,398

$94,111,121,124,141,145,147,154$, $162,165,170,179,180,193,309$, $316,330,336,340,341,404$

$86,92,97,107,111,119,121,124$, $147,170,173,291,321$

$87,112,121,156,182,228,313$

$112,114,320$

123,$179 ; 180$ 
Open-Pit Mining

Overburden

properties

Performance Bond System

Phosphate Mining and Reclamation slimes and waste disposal

Planning

$$
\begin{aligned}
& \text { bibliographies } \\
& \text { : } \\
& \text { environmental }
\end{aligned}
$$

land use

mine

pre-mining

reclamation

recreation

surface mining

\section{Pollution}

Policy Analysis

Poplar Trees
$177,315,317,405$

$145,178,179,215,228,230,313$, 323

$195, \cdot 210,218,304,308,352$

101,397

$115,136,190,204,353,372$

$88,138,212,223,280,284,286,287$

$188,318,342,377,380,383,384$

$10,14,21$

$21,23,68,87,194,315,316,326$, $332,348,355,387,391$

$32,43,188,195,202,320,328,335$, $357,358,362,363,367,371,373$, $375,381,383,385,389,391,396$, 401

$10,111,124,177,309,317 ; 318,328$, $333,334,350,376,377,378 ; 404,407$

$92,155,157,194,195,197,202,305$, $322,323,331,332,334,341,351,352$, $353,358,359,360,362$; 364, 368, 371, 374,385

$14,43,92,102,111,124,145,152$, $167,188,194,196,197,200,202$, $214,224,227,243,262,305,315$, $318,320,321,322,323,328,330$, $332,333,334,336,341,342,352$, $353,358,360,362,363,364,366$, $368,371,373,374,375,376,378$, $382,393,394,400$

$357,358,374$

$124,194,197,200,247,330,358,368$, $385,393,394$

$284,342,377,410$

$43,80,90,101,120$

251,252 
Public Involvement

Public Land

Quarrying

Range Improvement

Reclamation

alternatives

equipment

legal aspects - laws, legislation, regulations, requirements

methods

regional differentiation

Recreation

Reforestation

Refuse

Regulations

Remote. Sensing

Resources

Revegetation
$338,380,386$

$48,56,62,77,82,102$

$18,317,343,364,365,399,400,402$

7,263

see also Bauxite Mining, Bibllographies, Costs, Economics, Kaolin Minings, Land Use, Lignite Mining, Planning, Sand and Gravel Mining, Spoil, Surface Mining, Vegetation, Wild1ife

$30,59,98,132,134,135,168,184$, $185,191,192,193,196,197,199,200$, $204,240,295, .310,323,325,329,336$, $337,352,354,361$

188,416

$121,124,145,163,165,169,170,179$, $180,215,219,229,332,382$

$32,39,47,49,74,75,81,101,124$, $145,154,175,313,338,339,344,363$, $365,366,375,398,399,400,402,403$, 410,412

$86, .87,119,124,136,145,156,162$, $163,167,169,170,173,193,196,219$, $222,229,292,304,305,321,322,332$, $371,376,377,382,388,389$

111,124

$345,346,357,358,363,366,370,374$, 376

see Vegetation

$190,228,244,276,329,342,356,379$, 393,413

see Legal Aspects

$216,353,378,392,405,406$

$315,316,387$

see Vegetation 
Sand and Gravel Mining and Reclamation

\section{Slimes}

Slope Restrictions

Slope Stability

Soils

Spoil

$$
\begin{aligned}
& \text { bibliography } \\
& \text { handling }
\end{aligned}
$$

reclamation

stabilization

Strip Mining

Surface Mining and Reclamation

bibliography

costs

economics

efficiency

equipment

lega1 aspects - laws, legislation, regulations
$151,205,252,330,337,357,362,363$, $364,376,377,381,382,403,404,411$

see Phosphate Mining and Reclamation

$70,92,409$

$15,92,158,221,228,302$

$29,158,218,220,223,224,225,227$, $232,233,234,235,239,244, .250$, $263,275,304,309,363,389$

$189,224,308,316,323,389$

8,15

$119,147,162,163,219,238,273,306$, 332,340

$24,118,119,147,162,193,199,200$, $202,209,219,243,263,269,271,273$, $278,298,304,305,315,332,375$

221,228

see Surface Mining

see also Mining

$30, .35,45,87,119,120,121,122,144$, $148,149,150,153,159,161,164,171$, $186,189,210,264,347,367,369,386$, $406,408,424$

$4,5,6,11,12,16,17,18,19,23$, $26,27,28$

$70,85,86,89,90,93,95,97,98$, $101,107,108,109,121,167,170$, $173,188,193,217,332,333,374,409$

$5,90,92,94,111,113,114,297,416$

$163,297,332$

$94,111,129,141,160,163,170,187$ 271,315

$32,34,36,37,38,43,46,52,64$, $65,70,73,79,81,92,98,101,109$, $130,175,374$ 
Surface Mining and Reclamation (Continued)

methods and techniques

reclamation

regional differentiation

slope restrictions

\section{Tailings}

Taxation

Topsoil

Uranium

Valley Fill Method

Vegetation and Reclamation

Waste Disposa1

$\cos t s$

phosphate mining
$97,111,124,125,126,128,130,131$, $136,139,140,142,146,147,152$, $158,170,171,172,173,174,176$, $178,188,192,193,196,332,333$, $339,354,355$

$4,5,12,18,19,35,43,49,61,70$, $74,75,85,86,92,97,101,107,108$, $114,119,124,136,145,152,170,172$, $173,174,175,190,193,196,199$, $201,202,206,207,208,210,213,228$, $230,242,249,267,297,298,305$, $306,308,314,321,322,323,324,327$, $332,336,353,354,358,366,368,374$, $375,389,393,394,400,402,409$, 414,416

$111,266,297$

$70,92,409$

$211,263,315$

$84,91,100,106,117$

$101,193,304,308,323$

288,395

$111,145,196$

$24,98,124,147,168,193,203,220$, $224,228,231,238,239,241,242$, $243,244,245,249,250,253,263$, $264,266,267,271,272,273,274$, $275,296,297,304,305,306,308$, $309,313,327,332,336,371,375$, 389

$202,240,269,335$

$169,202,241,243,246,247,248$, $251,252,254,255,256,257,258$, $259,260,262,268,270,353$

$211,239,245,307,315,329,354$, 382,411

88

$88,138,284,386,387,423$ 
Wa ter

$3,25,196,230,277,279,281,282$, $283,288,293,304,316,334,353$, $368,380,385$

Wheel Excavation

$124,162,323$

Wild1ife

$120,226,315,327,353,375$

Zoning

$69,317,318,323,343,365,397$, $398,403,404$ 
THIS PAGE

WAS INTENTIONALLY

LEFT BLANK 
Appalachia

Alabama

Arizona

Atlanta

Australia

British Columbia

California.

Canada

Color ado

Florida

Georgia

Germany

Great Britain

Great Plains

Hawai.i

Illinois

Indiana

International

Kansas

Kentucky

Maryland

Midwest
$38,39,40,59,66,85,86,92,97$, $107,119,122,145,147,149,167$, 173,175

144

289,315

417

18

192

$364,399,402$

168

204,382

$88,115,136,138,204,212,223,280$, $284,2.36,287,372,423$

$169,365,417$

124

$322,329,370$

$1,175,206,209,306,308,309,310$, 421

$235,236,237$

$188,227,241,253,278,321,365$, $369,400,404$

$37,105,189,201,247,321,414$

29,294

$209,268,298$

$38,69,72,98,150,156,184,321$, $336,383,384,389$

39

$85,86,121,154,256,321$ 
Missouri

Missouri River Basin

Montana

New Mexico

North America

Nor th Dakota

Ohio

Pennsylvania

Powder River Basin

South Dakota

United States

southeastern

western

Utah

Virginia

West Virginia

Wisconsin

Wyoming
321

78,355

$41,49,60,83,100,117,118,764$, $209,300,304,305,310,407$

$231,238,273$

313

$32,71,78,137,266,299,352,401$

$39,95,116,130,248,251,258, .321$, $343,347,358,374,422$.

$38,39,98,130,147,167,200,217$, $255,342,349,356,365,375,393$, 394

320

76

$17, \ldots 57,62,79,93,111,121,163$, $205,213,297,333,339,353,354$, 412,418

115

$3,7,9,13,20,43,50,54,62,102$, $229,312,313,324,344,387$

263

$98,187,327$

$38,39,89,98,128,174,270$

$183,328,398$

$56,209,275,320$ 